


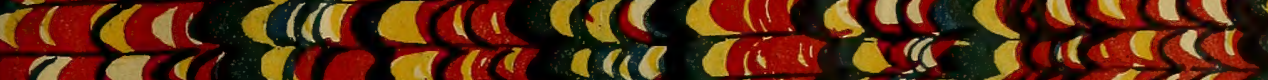

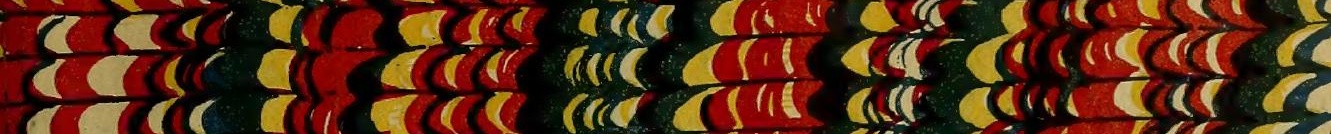

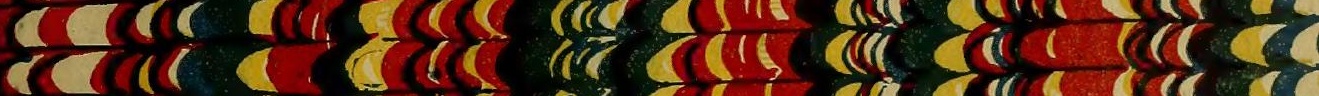

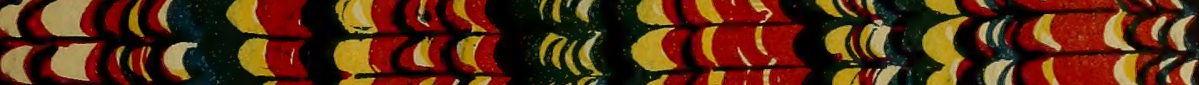

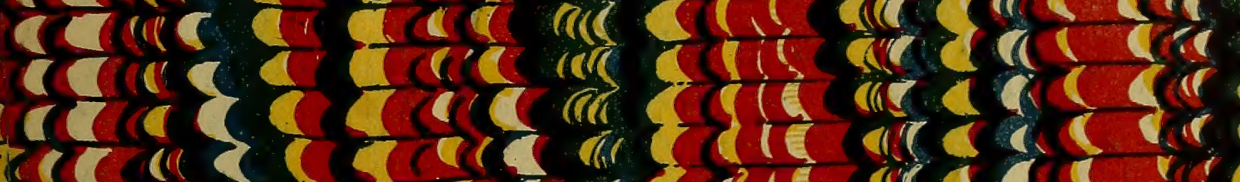

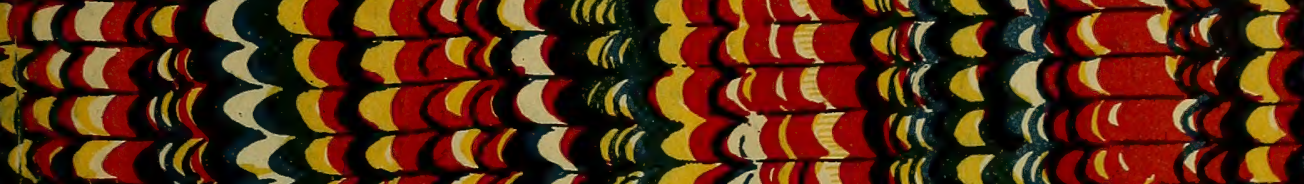
यदि

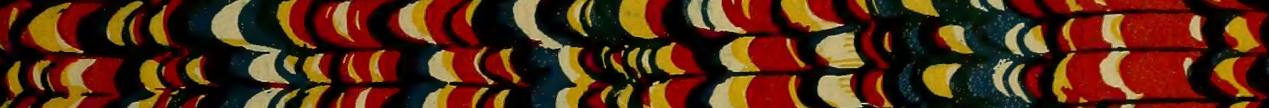

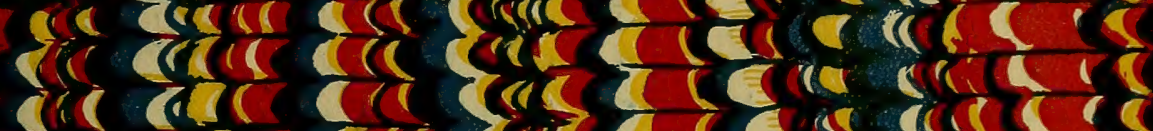

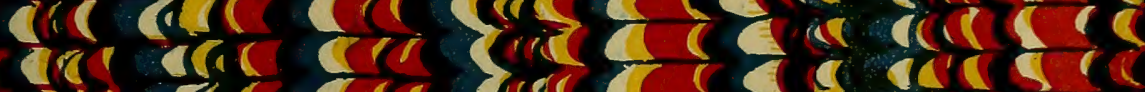

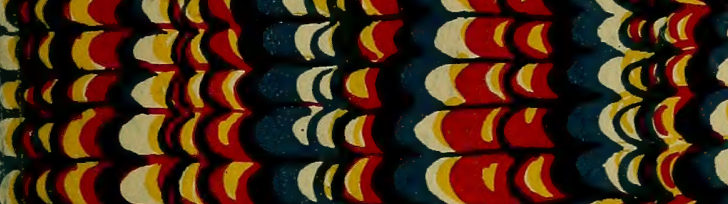

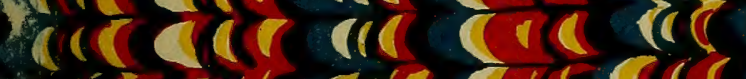

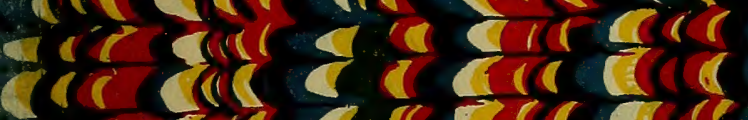

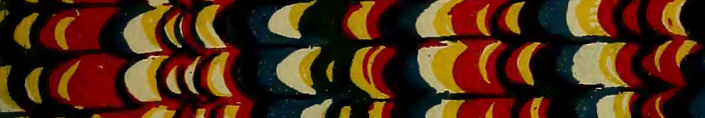
$\operatorname{lic} 810$

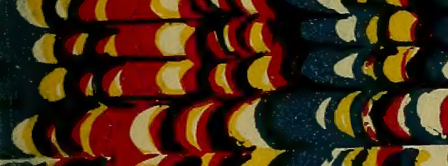
$\operatorname{cic} 10$

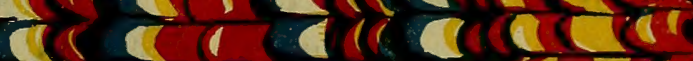

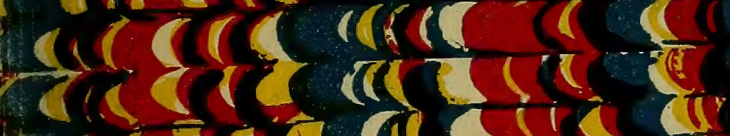

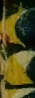
intes ac

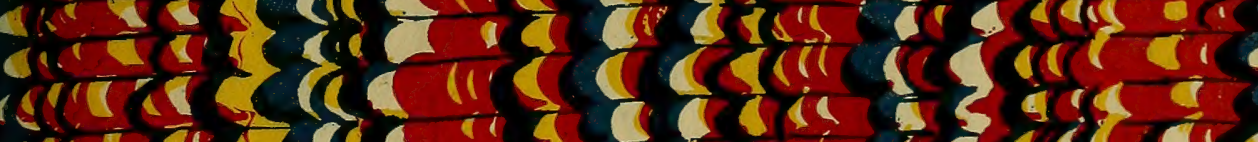

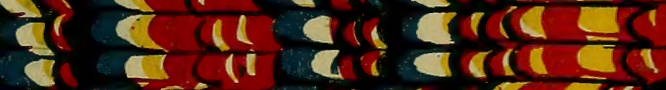
a.

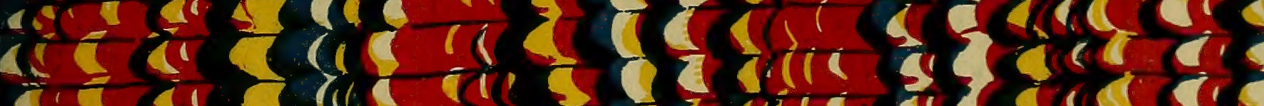

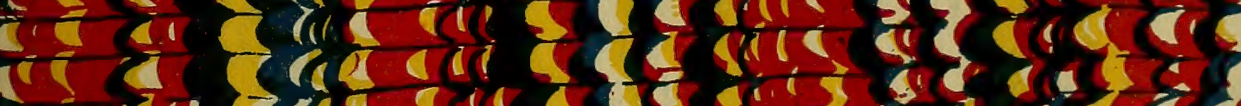

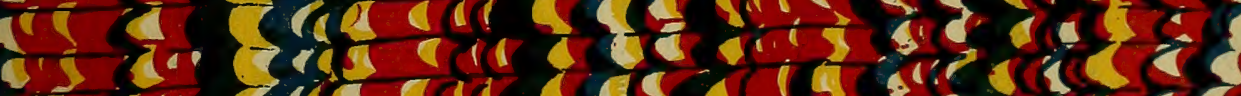

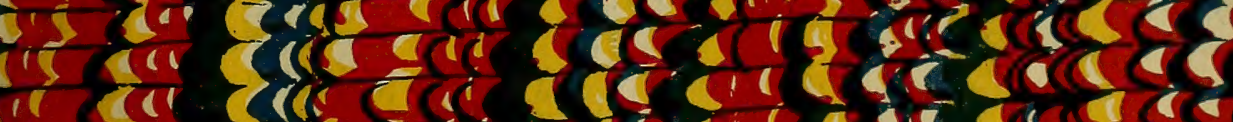

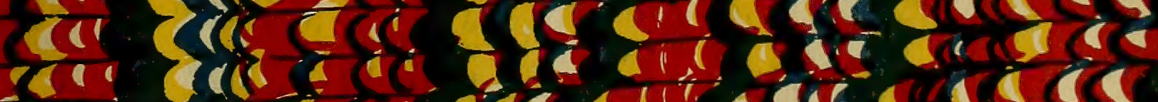

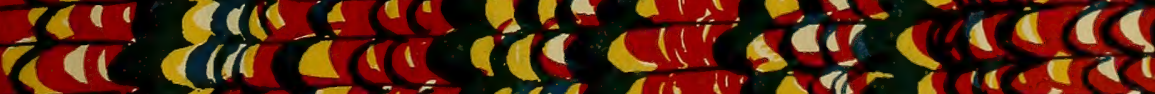

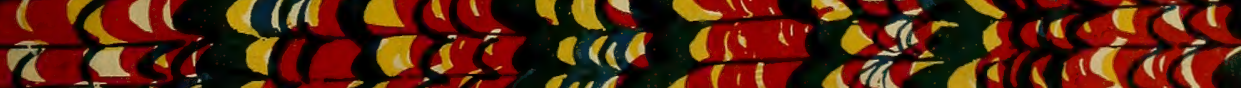

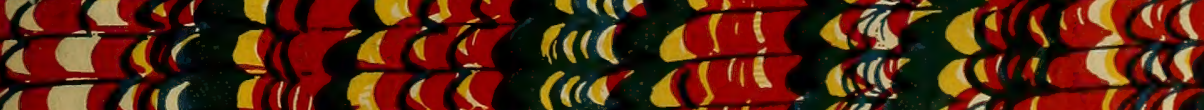

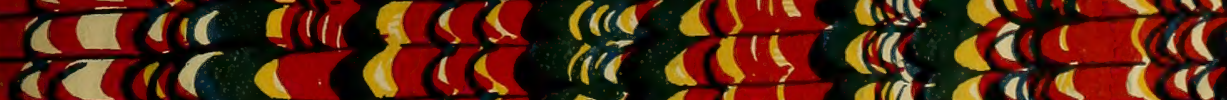
- - 



\title{
DESCRIPTIONS OF THE ALCYONARIA COLLECTED
}

\section{BY THE U. S. FISHERIES STEAMER "ALBATROSS,"}

MAINLY IN JAPANESE WATERS, DURING 1906

\author{
BY \\ CHARLES C. NUTTING \\ Professor of Zoology, State University of Iowa
}

No. 1923.-From the Proceedings of the United States National Museum,

Vol. 43, pages 1-104, with Plates 1-21

Published November 23, 1912

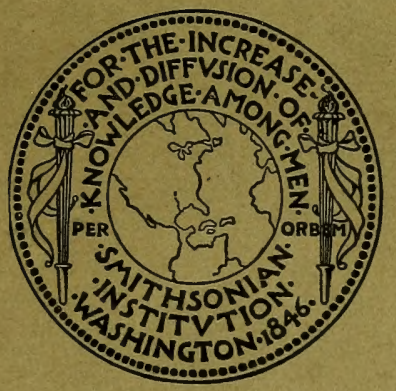

Washington

Government Printing Office 



\section{DESCRIPTIONS OF THE ALCYONARIA COLLECTED}

\section{BY THE U. S. FISHERIES STEAMER "ALBATROSS," \\ MAINLY IN JAPANESE WATERS, DURING 1906}

\section{BY}

\section{CHARLES C. NUTTING}

Professor of Zoology, State University of Iowa

No. 1923.-From the Proceedings of the United States National Museum, Vol. 43, pages 1-104, with Plates 1-21

Published November 23, 1912

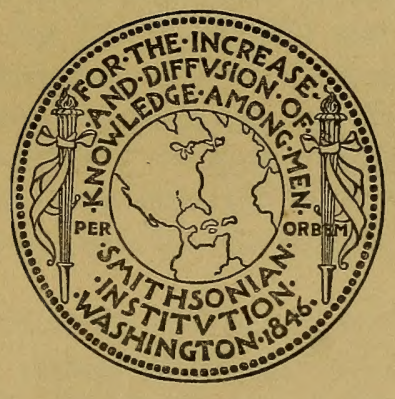

Washington

Government Printing Office 



\title{
DESCRIPTIONS OF THE ALCYONARIA COLLECTED BY THE U. S. FISHERIES STEAMER “ALBATROSS," MAINLY IN JAPANESE WATERS, DURING 1906.
}

\author{
By Charles C. Nutting, \\ Professor of Zoology, State University of Iowa.
}

\section{INTRODUCTION.}

But an insignificant proportion of the alcyonarian material collected by the U. S. Fisheries steamer Albatross during her cruise in the Northwest Pacific during 1906 was secured outside of Japanese waters. Hence this paper is substantially a contribution to our knowledge of the Japanese Alcyonaria.

The surprising richness of the marine fauna in the vicinity of Japan has long been recognized, and the extent of the collection of Alcyonaria secured by the Albatross was, in some degree at least, anticipated, although the number of new forms is somewhat greater than might have been expected, especially in view of the number of excellent papers that have appeared in recent years treating of the Alcyonaria of those regions.

A number of more or less extensive collections have made their way to European museums and have been reported on by various writers. Perhaps the most important of these collections was that made during $1904-5$ by Dr. F. Doflein and reported on by Prof. W. Kükenthal, who has discussed the Alcyonacea and Gorgonacea ${ }^{1}$ in three masterly monographs, giving excellent discussions of these groups in general, as well as of the species cellected by Doctor Doflein. The Pennatulacea are being reported on by Dr. H. Balss, who has given some preliminary descriptions in the Zoologischer Anzeiger for 1909 .

A notable work, Primnoidæ von Japan, by K. Kinoshita, appeared in the Journal of the College of Science of the Imperial University of Tokyo, 1908. The descriptions and figures in this work are excellent, and proved an unusually efficient aid in identification of species in the progress of the present work.

1 Beitrage zur Naturgeschichte Ostasiens. Herausgegeben von Dr. F. Doflein, Japanische Alcyonaceen, 1906; Japanische Gorgoniden, Teil I, 1908; Teil II, 1909. 
Wright and Studer, in their report on the Alcyonaria of the Chatlenger expedition, described a number of species from Japanese waters, and others have since been reported from that region.

In view of these comprehensive monographs and other less pretentious papers, it would seem that the alcyonarian fauna of the Japanese region had been pretty thoroughly worked, and that further investigations of the same region would not be very profitable, at least:so far as the discovery of new forms is concerned. On the contrary, however, the collection secured by the Albatross is of exceptional interest, adding many species, most of which are new, to the already extensive list from that region, as well as furnishing numerous items of interest concerning the geographical distribution of the group.

As a whole the Japanese Alcyonaria are more circumscribed in their distribution than one would consider likely, there being comparatively few species found both in Japanese waters and other parts of the Western Pacific, as is well shown in comparing the lists of species in the present work with those found in the monographic reports on the alcyonarians of the Gulf of Manaar by Thomson and Henderson, ${ }^{1}$ and the two bulky works which constitute the reports on the Alcyonaria secured by the Investigator in the Indian Ocean. ${ }^{2}$ Such a comparison shows that the faunæ of the Indian Ocean and of Japan are by no means intimately related, reminding one of the same condition of affairs found in the Caribbean Sea as compared with the adjacent waters of the North Atlantic.

SYSTEMATIC SYNOPSIS OF ALCYONARIANS COLLECTED BY THE U. S. FISHERIES STEAMER "ALBATROSS" IN THE NORTHWEST PACIFIC DURING 1906.

[The asterisk (*) indicates a new genus or species.]

Order ALCYONACEA.

Family Cornularid在.

Clavularia dispersa, C. sulcata, ${ }^{*}$ C. eburnea, C. japonica.*

Family NepHTHYid

Lithophytum roseum.*

Dendronephthya splendens, $D$. acaulis, $D$. magnacantha, ${ }^{*} D$. nigripes, ${ }^{*} D$. oviformis.*

Paraspongodes striata.

Family Alcronida.

Alcyonium kükenthali,* A. gracillimum.

Nidatia rubra, N. gracilis.*

Bellonella flava**

Anthomastus japonicus.*

1 Report on the Pearl Oyster Fisheries of the Gulf of Manaar, The Alcyonaria, 1905.

2 Thomson and Henderson, Report on the Alcyonarians collected by R. T. M. S. S. Investigator in the Indian Ocean. 1 The Alcyonaria of the Deep Sea, 1906; 2. (Thomson and Simpson) The Alcyonaria of the Littoral Zone, 1909. 
Siphonogorgia splendens.

Family SipHoNOGORGID瓜.

\section{Order PENNATULACEA.}

Ptilosarcus brevicaulis.*

\section{Family Pennatulide.}

Pennatula aculeata, $P$. sulcata, $P$. murrayi, $P$. pendula, $P$. naresi. $P$. longistyla, ${ }^{*} P$. rubescens, ${ }^{*} P$. brevipenna, ${ }^{*} P$. inermis. ${ }^{*}$

Pteroides sagamiense.

Halisceptrum gustavianum, H. cystiferum, H. album.*

Virgularia, sp.?

Family Virgularider.

Balticina finmarchica, B. pacifica, B. californica.

Halipteris christii.

\section{Family UMBELLULID五.}

Umbellula magniflora, U. carpenteri, U. eloisa.*

Family КорновеLемNonide.

Kophobelemnon ferrugineum, $K$. hispidum.*

Family AnthoptLid 正.

Anthoptilum murrayi.

Family EchinoptiLID无.

Echinoptilum macintoshi.

Family Protoptilide.

Protoptilum orientale.*

Stachyptilum macleari.

Trichoptilum spinosum.*

Helicoptilum * rigidum.*

Order GORGONACEA.

Suborder HOLAXONIA.

Family CHRYsogorgid死.

Lepidogorgia petersi.

Chrysogorgia lata, C. flexilis, C. agassizii, C. dichotoma.

Family Primnoids.

Calyptrophora ijimai, C. japonica, C. kerberti.

Stachyodes megalepis.

Caligorgia flabellum, C. ventrilabrum, C. aspera.

Plumarella spinosa, $P$. flabellata, $P$. carinata, $P$. spicata, ${ }^{*} P$. adhærans.*

Thouarella hilgendorfi, T. recta, ${ }^{*}$ T. typica, T. striata, T. alternata.*

Primnodendron * superbum.*

\section{Family Muriceides.}

Acanthogorgia striata, A. fusca,* A. paradoxa.*

Anthomuricea aberrans.*

Muriceides cylindrica,* M. nigra.*

Muriceila reticulata, ${ }^{*}$. abnormalis.*

Thesea placoderma.

Acis squamata, A. spinifera.* 
Placogorgia japonica.*

Villogorgia brunnea.*

Elasmogorgia filiformis, E. ramosa.*

Menella indica.

Bebryce hicksoni.

Family Plexauride.

Euplexaura pinnata.

Family ISID 2.

Acanella normani.

Bathygorgia profunda.

Ceratoisis paucispinosa, C. philippinensis.

Melitodes dichotoma.

Parisis fruticosa.

Family GorgonIDE.

Platycaulus danielssenı.

Leptogorgia beringi.*

Callistephanus pacificus.*

Family Gorgonelidde.

Scirpearella gracilis, S. rubra.

Suborder SCLERAXONIA.

Family Briareider.

Paragorgia nodosa, $P$. regalis.*

The above list shows that the collection contains 102 species of Alcyonaria distributed among 54 genera belonging to 18 families. There are 40 new species and 2 new genera. The Muriceidæ includes the largest number of genera (11) and 17 species. The family containing the greatest number of species is the Primnoidæ, with 18 species and 1 new genus.

The genus represented by the largest number of species is Pennatula, with 9 species, 4 of which are new, and this genus probably has the greatest geographical range.

The 40 new species, constituting just about 39 per cent of the whole number, are pretty well distributed over the various families and genera of the order, although there is a proportionally greater number in the family Muriceidæ than in any other, 11 of the 17 species of this family being new. Of the 18 species of the Primnoidæ but 5 are new. 
Record of dredging stations at which Alcyonaria were secured during the northwest Pacific cruise of the "Albatross" in 1906.

\begin{tabular}{|c|c|c|c|c|}
\hline $\begin{array}{l}\text { Station } \\
\text { number. }\end{array}$ & Position. & $\begin{array}{l}\text { Depth in } \\
\text { fathoms. }\end{array}$ & Kind of bottom. & Species of Alcyonaria. \\
\hline 4765 & $\begin{array}{l}\text { West pt. Yunaska Id., S. } \\
37^{\circ} \text { E., } 43.5 \text { miles. }\end{array}$ & 1,217 & Fine black sand....... & Anthoptilum murrayi. \\
\hline 4766 & $\begin{array}{l}\text { Koniuji Id., S. } 22.5^{\circ} \text { W., } 27 \\
\text { miles. }\end{array}$ & 1,766 & No specimen....... & Pennatula aculeata, Bathygor- \\
\hline 4768 & $54^{\circ} 20^{\prime} 30^{\prime \prime}$ N.; $179^{\circ} 09^{\prime} 30^{\prime \prime}$ E. & 764 & $\begin{array}{l}\text { Green-brown mud: } \\
\text { fine black sand. }\end{array}$ & Balticina pacifica. \\
\hline $\begin{array}{l}4769 \\
4771\end{array}$ & $\begin{array}{l}54^{\circ} 30^{\prime}, 40^{\prime \prime} \mathrm{N} . ; 179^{\circ} 14^{\prime} \mathrm{E} . \ldots . \\
54^{\circ} 30^{\prime} \text { N.; } 179^{\circ} 17^{\prime} \mathrm{E} . \ldots . . .\end{array}$ & $\begin{array}{r}244-237 \\
426\end{array}$ & $\begin{array}{l}\text { Gray sand; green mud. } \\
\text { Broken shells.......... }\end{array}$ & $\begin{array}{l}\text { Plumarella spinosa. } \\
\text { P Plumarella spicata, ? Thoua- } \\
\text { rella hilgendorfi. }\end{array}$ \\
\hline $\begin{array}{l}4772 \\
4778\end{array}$ & $\begin{array}{l}54^{\circ} 30^{\prime} 30^{\prime \prime} \text { N.; } 179^{\circ} 14^{\prime} \mathrm{E} . . . \\
\text { Semisopochnoi Id., r. t. S. } \\
45^{\circ} \mathrm{W} \text {., 1.t. S. } 12^{\circ} \text { W., about } \\
12 \text { miles. }\end{array}$ & $\begin{array}{r}344-372 \\
43-33\end{array}$ & $\begin{array}{l}\text { Greenish brown sand.. } \\
\text { Fine black gravel..... }\end{array}$ & $\begin{array}{l}\text { Paragorgia nodosa. } \\
\text { Thouarella striata, Primnoden- } \\
\text { dron superbum. }\end{array}$ \\
\hline 4780 & $52^{\circ} 01^{\prime}$ N.; $174^{\circ} 39^{\prime}$ E........ & 1,046 & $\begin{array}{l}\text { Gras mud; sand; peb- } \\
\text { bles. }\end{array}$ & $\begin{array}{l}\text { Plumarella spicata, Leptogor- } \\
\text { gia beringi. }\end{array}$ \\
\hline 4781 & $52^{\circ} 14^{\prime} 30^{\prime \prime}$ N.; $174^{\circ} 13^{\prime}$ E.... & 482 & $\begin{array}{l}\text { Fine gray sand; peb- } \\
\text { bles. }\end{array}$ & $\begin{array}{l}\text { Clavularia eburnea, Plumarella } \\
\text { spinosa, Muriceides cylin- } \\
\text { drica, Callistephanus pacifi- } \\
\text { cus. }\end{array}$ \\
\hline 4784 & $\begin{array}{l}\text { East Cape, Attu Id., S. } 18^{\circ} \\
\text { W., } 4 \text { miles. }\end{array}$ & 135 & Coarse pebbles........ & $\begin{array}{l}\text { Plumarella flabellata, Muri- } \\
\text { ceides nigra. }\end{array}$ \\
\hline 4787 & $\begin{array}{l}\text { North pt. Copper Id., N. } 79^{\circ} \\
\text { E., } 8.5 \text { miles. }\end{array}$ & $54-57$ & Green sand.. & Plumarella spinosa. \\
\hline 4791 & $\begin{array}{l}\text { Cape Monati, Bering Id., N. } \\
52^{\circ} \mathrm{W} ., 8.75 \text { miles. }\end{array}$ & $76-72$ & Rocky............ & Clavularia sulcata. \\
\hline 4792 & $\begin{array}{l}\text { Cape Monati, Bering Id., N. } \\
50^{\circ} \text { W., } 8.2 \text { miles. }\end{array}$ & 72 & Pebbles......... & Balticina pacifica. \\
\hline 4793 & $\begin{array}{l}\text { Torperkov Id., Hbr. of } \\
\text { Nikolski, Bering Id., N. } \\
58^{\circ} \text { E., } 44 \text { miles. }\end{array}$ & 2,700 & & ? Helicoptilum rigidum. \\
\hline 4807 & $\begin{array}{l}\text { Cape Tsiuka, S. } 58^{\circ} \text { W., } 10.3 \\
\text { miles. }\end{array}$ & $44-47$ & Shells; coarse gravel... & $\begin{array}{l}\text { Nidalia rubra, Ptilosarcus } \\
\text { brevicautis. }\end{array}$ \\
\hline $4 \mathrm{~S} 08$ & $\begin{array}{l}\text { Cape Tsiuka, S, } 61^{\circ} \mathrm{W} ., 10.6 \\
\text { miles. }\end{array}$ & 47 & $\begin{array}{l}\text { Sand; shells; coarse } \\
\text { gravel. }\end{array}$ & $\begin{array}{l}\text { Ptilosarcus brevicaulis, Halis- } \\
\text { ceptrum gustavianum, Meli- } \\
\text { todes dichotoma. }\end{array}$ \\
\hline 4815 & $\begin{array}{l}\text { Niigata Lt., S. } 25^{\circ} \text { E., } 21.5 \\
\text { miles. }\end{array}$ & 70 & Dark green sand ....... & $\begin{array}{l}\text { Nidalia rubra, Siphonogorgia } \\
\text { splendens, Pennatula long- } \\
\text { istyla, }\end{array}$ \\
\hline 4817 & $\begin{array}{l}\text { Niigata Lt., S. } 29^{\circ} \text { E., } 18 \\
\text { miles. }\end{array}$ & 61 & Fine gray sand... & Halisceptrum album. \\
\hline 4837 & $\begin{array}{l}\text { Tateisha Zaki Lt., S. } 53^{\circ} \text { E., } \\
8 \text { miles. }\end{array}$ & 57 & Brown-green mud.... & Elasmogorgia filiformis. \\
\hline 4842 & $\begin{array}{l}\text { Saigo Misaki (Dogo Id.), S. } \\
64^{\circ} \text { W., } 6.1 \text { miles. }\end{array}$ & 82 & Fine green sand; shells. & Echinoptilum macintoshi. \\
\hline 4876 & $\begin{array}{l}\text { Oki Shima, S. } 29^{\circ} \text { W., } 5.3 \\
\text { miles. }\end{array}$ & 59 & $\begin{array}{l}\text { Fine gray sand; broken } \\
\text { shells. }\end{array}$ & $\begin{array}{l}\text { Ptilosarcus brevicaulis, Pen- } \\
\text { natula inermis, Haliscep- } \\
\text { trum album. }\end{array}$ \\
\hline 4879 & $\begin{array}{l}\text { Oki Shima, S. } 70^{\circ} \text { W., } 7.5 \\
\text { miles. }\end{array}$ & 59 & .....do.............. & $\begin{array}{l}\text { Dendronephthya acaulis, } D \text {. } \\
\text { splendens. }\end{array}$ \\
\hline 4888 & $\begin{array}{l}\text { Nomo Zaki, N. } 57^{\circ} \text { E., } 16.5 \\
\text { miles. }\end{array}$ & 71 & $\begin{array}{l}\text { Dark gray sand; bro- } \\
\text { ken shells. }\end{array}$ & $\begin{array}{l}\text { Clavularia japonica, Dendro- } \\
\text { nephthya oviformis. }\end{array}$ \\
\hline 4890 & $\begin{array}{l}\text { Ose Saki Lt., N. } 2^{\circ} \text { W., } 10 \\
\text { miles. }\end{array}$ & 135 & Rocky.............. & $\begin{array}{l}\text { A canthogorgia paradoxa, Meli- } \\
\text { todes dichotoma. }\end{array}$ \\
\hline 4893 & $\begin{array}{l}\text { Ose Saki Lt., N. } 29^{\circ} \text { E., } 5.5 \\
\text { miles. }\end{array}$ & $106-95$ & $\begin{array}{l}\text { Gray sand; broken } \\
\text { shells; pebbles. }\end{array}$ & $\begin{array}{l}\text { Clavularia japonica, Dendro- } \\
\text { nephthya splendens, Pluma- } \\
\text { rella carinata, Afuricella re- } \\
\text { ticulata, Parisis fruticosa, } \\
\text { Melitodes dichotoma, Scir- } \\
\text { pearella gracilis, S. rubra. }\end{array}$ \\
\hline 4894 & $\begin{array}{l}\text { Ose Saki Lt., N. } 41^{\circ} \text { E., } 5 \\
\text { miles. }\end{array}$ & 95 & $\begin{array}{l}\text { Green sand; broken } \\
\text { shells; pebbles. }\end{array}$ & $\begin{array}{l}\text { Clavularia japonica, Bellonella } \\
\text { flava, Siphonogorgia splen- } \\
\text { dens, Chrysogorgia dichotoma, } \\
\text { Plumarella adhxrans, P. } \\
\text { carinata, Thouarella typica, } \\
\text { A canthogorgia paradoxa, The- } \\
\text { sea placoderma, Euplexaura } \\
\text { pinnata, Parisis fruticosa. }\end{array}$ \\
\hline 4895 & $\begin{array}{l}\text { Ose Saki Lt., N. } 42^{\circ} \text { E., } 4.7 \\
\text { miles. }\end{array}$ & 95 & .....do.. & $\begin{array}{l}\text { Plumarella adhwrans, } P \text {. cari- } \\
\text { nata, Thouarella hilgendorf, } \\
\text { \& Muriceides cylindrica, } P a- \\
\text { risis fruticosa. }\end{array}$ \\
\hline 4918 & $\begin{array}{l}\text { Gwaja Shima, S. } 38^{\circ} \mathrm{E}, 34 \\
\text { miles. }\end{array}$ & 361 & $\begin{array}{l}\text { Gray sand; Globiger- } \\
\text { ina; broken shells. }\end{array}$ & Stachyodes megalepis. \\
\hline 4924 & $\begin{array}{l}\text { Nagada Saki, N. } 8^{\circ} \text { E., } 18 \\
\text { miles. }\end{array}$ & 159 & No specimen; rocky... & Calyptrophora japonica. \\
\hline 4934 & $\begin{array}{l}\text { Sata Misaki Lt, } N .77 .5^{\circ} \mathrm{E} \text {., } \\
7 \text { miles. }\end{array}$ & $152-103$ & Rocky.. & $\begin{array}{l}\text { Siphonogorgia splendens, Pen- } \\
\text { natula sulcata, P. murrayi, } \\
\text { Thouarella hilgendorfi. }\end{array}$ \\
\hline
\end{tabular}


Record of dredging stations at which Alcyonaria were secured during the northwest Pacific cruise of the "Albatross" in 1906-Continued.

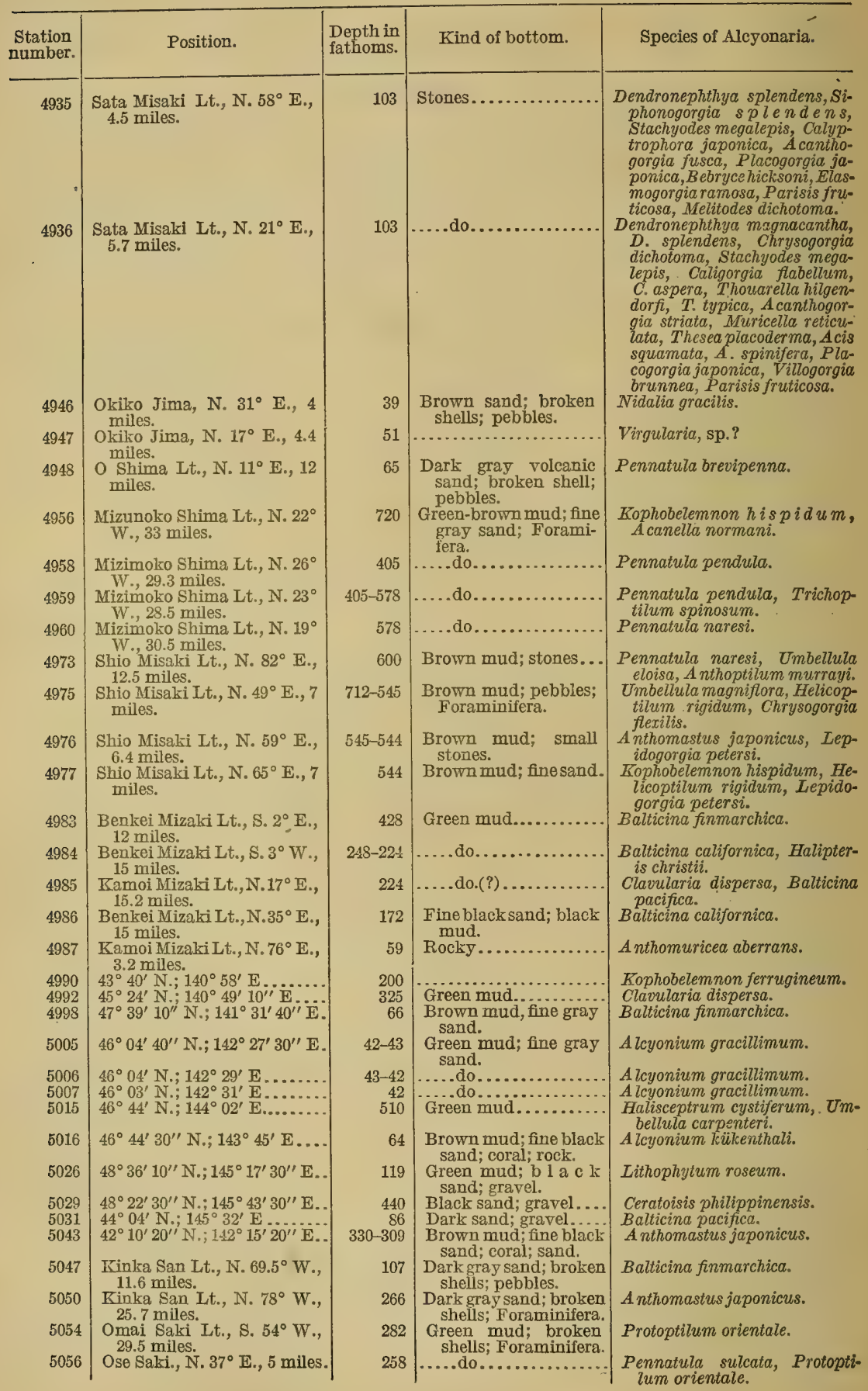


Record of dredging stations at which Alcyonaria were secured during the northwest Pacific cruise of the "Albatross" in 1906-Continued.

\begin{tabular}{|c|c|c|c|c|}
\hline $\begin{array}{c}\text { Station } \\
\text { number. }\end{array}$ & Position. & $\begin{array}{l}\text { Depth in } \\
\text { fathoms. }\end{array}$ & Kind of bottom. & Species of Alcyonaria. \\
\hline 5070 & Ose Saki, S. $8^{\circ}$.W., 1.8 miles. & 108 & $\begin{array}{l}\text { Mud; sand; broken } \\
\text { shells. }\end{array}$ & $\begin{array}{l}\text { Dendronephthya magnacantha, } \\
\text { Caligorgia aspera, Pluma- } \\
\text { rella adhærans, Thoucrella } \\
\text { hilgendorfi, Acanthogorgia } \\
\text { paradoxa, Mruricella abnor- } \\
\text { malis, Placogorgia japonica, } \\
\text { Afelitodes dichotoma. }\end{array}$ \\
\hline 5071 & $\begin{array}{l}\text { Ose Saki, S. } 53.5^{\circ} \text { W., } 2.6 \\
\text { miles. }\end{array}$ & 57. & $\ldots(?) \ldots$ & $\begin{array}{l}\text { Dendroncphthya acaulis, Para- } \\
\text { spongodes striata, Penna- } \\
\text { tula rubescens, Stachyptilum } \\
\text { macleari, Menella indica. }\end{array}$ \\
\hline 5072 & $\begin{array}{l}\text { Omai Saki Lt., S. } 37^{\circ} \text { W., } \\
11.7 \text { miles. }\end{array}$ & $284-148$ & Gray mud........ & Pennatula inermis. \\
\hline 5074 & $\begin{array}{l}\text { Omai Saki Lt., S. } 37.5^{\circ} \mathrm{W} \text {., } \\
6.4 \text { miles. }\end{array}$ & 47 & ......do. & Dendronephthya nigripes. \\
\hline 5079 & $\begin{array}{l}\text { Omai Saki Lt., N. } 29^{\circ} \text { E., } 24 \\
\text { miles. }\end{array}$ & $475-505$ & Pebbles..... & $\begin{array}{l}\text { - Chrysogorgia lata, Calyptro- } \\
\text { phora ijimai, Thouarella al- } \\
\text { ternata, T. recta, Paragor- } \\
\text { gia regalis. }\end{array}$ \\
\hline 5080 & $\begin{array}{l}\text { Omai Saki Lt., N. } 23.5 \text { E., } 28 \\
\text { miles. }\end{array}$ & 505 & $\begin{array}{l}\text { Fine gray sand; Glo- } \\
\text { bigerina. }\end{array}$ & $\begin{array}{l}\text { Umbellula carpenteri, Lepido- } \\
\text { gorgia petersi, Chrysogorgia } \\
\text { agassizit, Calyptrophora iji- } \\
\text { mai, Thouarella alternata. }\end{array}$ \\
\hline 5083 & $\begin{array}{l}\text { Omai Saki Lt., N. } 23.5^{\circ} \text { E., } \\
34.5 \text { miles. }\end{array}$ & 624 & ......do......... & Ceratoisis paucispinosa. \\
\hline 5087 & $\begin{array}{l}\text { Joka Sima Lt., S. } 84.5^{\circ} \text { E., } \\
14.8 \text { miles. }\end{array}$ & 614 & Green mud..... & Calyptrophora ijimai. \\
\hline 5091 & $\begin{array}{l}\text { Toga Shima Lt., N. } 15^{\circ} \mathrm{W} . \text {, } \\
4.2 \text { miles. }\end{array}$ & 197 & $\begin{array}{l}\text { Green mud; c o a rse } \\
\text { black sand; pebbles. }\end{array}$ & Chrysogorgia lata. \\
\hline 5092 & $\begin{array}{l}\text { Joga Shima Lt, N. } 19^{\circ} \mathrm{W} \text {., } \\
3.5 \text { miles. }\end{array}$ & 70 & Coarse black sand..... & Pennatula sulcata. \\
\hline 5093 & $\begin{array}{l}\text { Joga Shima Lt., N. } 8^{\circ} \text { W., } 5 \\
\text { miles. }\end{array}$ & 302 & ... do. & $\begin{array}{l}\text { Calyptrophora kerberti, Thoua- } \\
\text { rella hilgendorfi. }\end{array}$ \\
\hline
\end{tabular}

It appears that alcyonarians were secured from 75 stations during the cruise. The greatest yield was from station 4936, at a depth of 103 fathoms, where 16 species were secured; the next best haul being from station 4894, with a yield of 11 species. This last was almost equaled at station 4935 , where 10 species were dredged. Other good hauls were from station 4893, where 8 species were secured; and station 5070, yielding 8 species. All of these extraordinarily successful hauls were from depths ranging from 95 to 108 fathoms, and all were in Japanese waters.

The deepest haul was near Bering Island, where Heticoptitum rigidum, a species for which a new genus of pennatulids is described, was secured from a depth of 2,700 fathoms. At station 4766, near Koniuji Island, one of the Aleutian Group, in a depth of 1,766 fathoms Pennatula aculeata and Bathygorgia profunda were secured. At station 4765, Anthoptitum murrayi was dredged from 1,217 fathoms, and at station 4780, Plumarella spicata and Leptogorgia beringi from a depth of 1,046 fathoms. These were the four deepest hauls at which Alcyonaria were obtained. Of the 6 species from these depths, 3 are pennatulids, and 3 belong to the Gorgonacea, while all belong to families of wide distribution in the deep seas. 
Geographical and bathymetrical distribution of Alcyonaria collected by the "Albatross" in the northwest Pacific during 1906.

[The asterisk $(*)$ indicates a new species.]

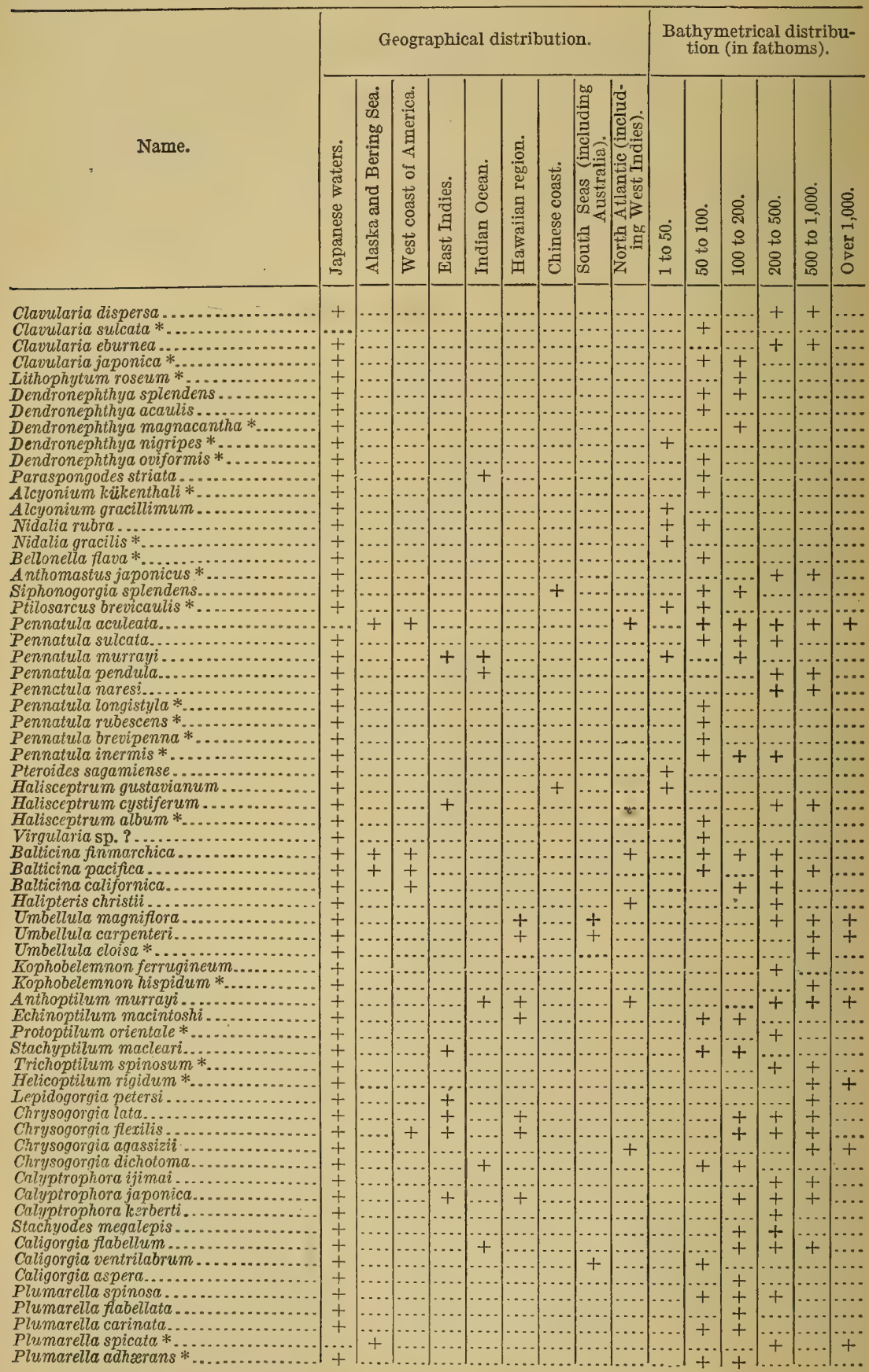


Geographical and bathymetrical distribution of Alcyonaria collected by the "Albatross" in the norlhwest Pacific during 1906-Continued.

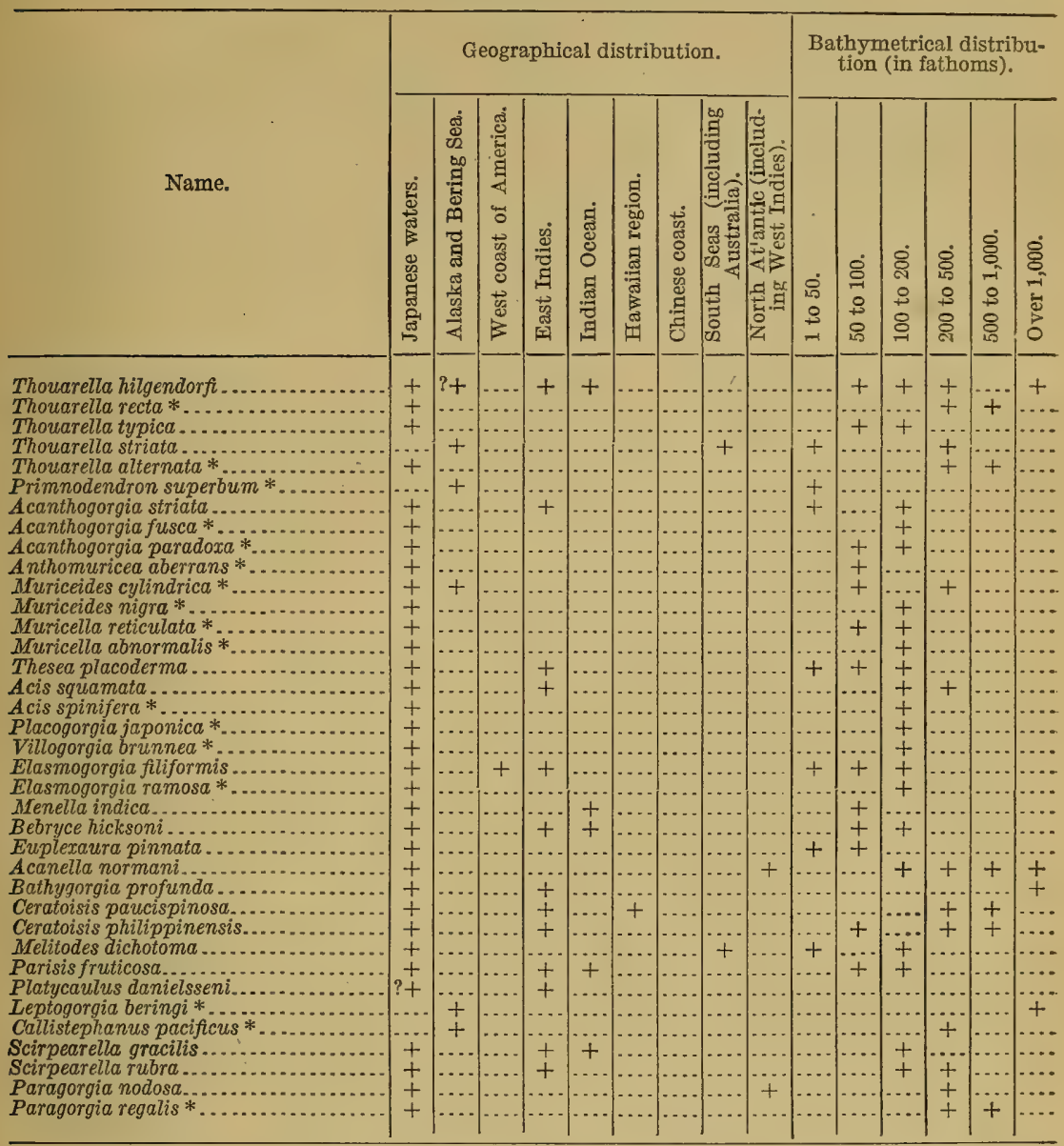

Of the 102 species secured, 96 have been reported from Japanese waters, and 60 are, so far as known, exclusively Japanese. Of the 37 Japanese species known to occur elsewhere 16, or 43 per cent, are from the East Indies; 8, or 22 per cent, are found in the Indian Ocean; 8, or 22 per cent, have been reported from the Hawaiian Islands, and but 1 from Chinese waters.

Four species are common to Japan and the South Seas, and 7 to Japan and the north Atlantic. Four of these latter are found nowhere else except in Japan and in the north Atlantic.

Five species are common to Japan and the north Pacific, including Alaska, and four are common to Japan and the west coast of America. 
It is interesting to note in this connection that there are more species common to Japan and the west coast of North America than to the Hawaiian region and the west coast of North America. ${ }^{1}$

An inspection of the table headed "Bathymetrical distribution" shows that the depth between 100 and 200 fathoms yielded the best results, 45 species being secured from that depth. The depth of from 50 to 100 fathoms appears to come next in order, with a record of 41 species, although a less range of depth is here included than in the 100 to 200 fathom column. A very common source of error in discussing such tables lies in the fact that no attention is ordinarily given to the number of hauls taken in each zone.

An examination of the records shows that alcyonarians were secured from 75 stations during the cruise. A depth of 1 to 50 fathoms is recorded for 8 stations, 50 to 100 fathoms at 22 stations, 100 to 200 fathoms at 14 stations, 200 to 500 fathoms at 18 stations, 500 to 1,000 fathoms at 12 stations, and over 1,000 fathoms at 4 stations. Calculating the number of species to 100 stations in each of these zones, we reach the following result:

In the 1 to 50 fathom zone the rate was 162 species to 100 hauls.

In the 50 to 100 fathom zone the rate was 200 species to 100 hauls.

In the 100 to 200 fathom zone the rate was 333 species to 100 hauls.

In the 200 to 500 fathom zone the rate was 172 species to 100 hauls.

In the 500 to 1,000 fathom zone the rate was 200 species to 100 hauls.

In depths of 1,000 fathoms or more the rate was 225 species to 100 hauls.

This shows still more clearly that the richest grounds were at depths between 100 and 200 fathoms. In order, however, to compare zones of equal depths we should add the 1 to 50 fathom and the 50 to 100 fathom zones, in order to compare with the 100 to 200 fathom zone. When this is done we find that the zone 1 to 100 fathom yielded species at the rate of 183 to 100 hauls, which still further emphasizes the difference between the two; showing that the second, or 100 to 200 fathom zone, yields twice the number of species to 100 hauls that were secured at depths under 100 fathoms.

Below 200 fathoms the ratio is still maintained fairly well, the average being about two species to each successful haul at all depths explored. The number of hauls, however, in the deeper zones was too small to give conclusive evidence. It nevertheless indicates, in a general way, that the bathymetric distribution is more equable than has generally been supposed, and that the deeper zones seem to yield as much in proportion to the number of successful hauls as the shallower, with the exception of the 100 to 200 fathom zone, which seems particularly -adapted to alcyonarian life.

${ }^{1}$ A discussion on this point will be found in my Descriptions of Hawaiian Alcyonaria, Proc. U. S. Nat. Mus., vol. 34, 1908, p. 548。 
As before stated, Helicoptitum rigidum, representing a new genus and species, was secured at a depth of 2,700 fathoms off Bering Island. So far as the writer has been able to ascertain, this is the greatest depth from which an alcyonarian of any kind has thus far been dredged. This form is also unique among the Pennatulacen on account of its extreme rigidity, being possessed of an exceedingly dense and heavy axis cylinder with a remarkably compact cortex of spicules.

No specimens were secured between the extreme depth just mentioned (2,700 fathoms) and 1,766 fathoms where two previously described species were secured as noted on page 7 .

SYSTEMATIC DISCUSSION OF THE ALCYONARIA SECURED BY THE U. S. FISHERIES STEAMER "ALBATROSS" DURING ITS CRUISE IN THE NORTHWEST PACIFIC IN 1906.

\section{Order ALCYONACEA Verrill.}

Polyps single or in fixed colonies, without an axis cylinder.

\section{Family CORNULARID E Verrill.}

Polyps united by solenia; colonies sometimes forming lobular encrusting masses, sometimes branching through new polyps budding from the sides of older ones.

\section{Genus CLAVULARIA Quoy and Gaimard (modified by Nutting).}

Spicules present. Colonies consisting of band-like stolons, from which the polyps arise singly, or of branched forms arising from a stolon-like or encrusting base. ${ }^{1}$

\section{CLAVULARIA DISPERSA Kiikenthal.}

Clavularia dispersa KüKENTHAL, Japanische Alcyonaceen, 1906, p. 18.

Colonies growing on very dark-colored worm tubes, broken, the largest fragment being $15 \mathrm{~cm}$. long; but the worm tube is $9.2 \mathrm{~cm}$. longer. The colony rather thinly encrusts the tube, which, with the alcyonarian, is about $4 \mathrm{~mm}$. in diameter. The polyps are distributed without any regularity whatever, sometimes being in clumps or clusters, and at others being as much as $6 \mathrm{~mm}$. apart.

The calyces are tubular or conical, a typical one being $3 \mathrm{~mm}$. in height and about as broad at base as high, their walls filled with rather slender spindles $1 \mathrm{~mm}$. long and longitudinally arranged. Sometimes there are 8 longitudinal corrugations on the calyx walls,

1 C. C. Nutting, Descriptions of Hawaiian Alcyonaria, Proc. U. S. Nat. Mus., vol. 34, p. 553. In this paper and another on Alcyonaria of the Californian coast (same publication, vol. 35, pp. 681-727) the writer gives short diagnostic definitions of families and genera. In the present work these definitions will be used so far as they appear to the writer to be satisfactory. 
and at others these are not evident. The polyps are often extruded above the calyces, their walls are filled with slender spindles vertically disposed, and are longitudinally corrugated with 8 ridges on which the spindles sometimes assume an en chevron arrangement. The tentacles bear numerous minute spindles irregularly disposed over their dorsal surfaces.

The cœnenchyma is packed with slender spindles, like those of the polyps and calyx walls. They are usually vertically disposed, but are sometimes crossed in various directions.

The color of the colonies is light grayish yellow.

Localities.-Station 4992; Bomasiri Shima (off north end of Rebun To), Sea of Japan; 325 fathoms. Station 4985; Kamoi Mizaki Light, N. $17^{\circ}$ E., 15.2 miles; 224 fathoms.

Type-Zocality.-Japan Sea, 1,000 meters.

Apparently near Sympodium indicum Thomson and Henderson.1 These writers describe several species of Sympodium which would go into the genus Clavularia, as used in this paper.

CLAVULARIA SULCATA, new species.

Plate 1, figs. 2, $2 a$; plate 17, fig. 1.

The largest colony is growing on a worm tube, and is $3.6 \mathrm{~cm}$. in height. The polyps are thickly emplanted over the distal portion of the tube. Another colony grows in a straggling manner over a pebble. The calyces are bent so as to be directed upward.

- A typical calyx is $1 \mathrm{~cm}$. in height, club-shaped, $3 \mathrm{~mm}$. broad at the clavate end and $2 \mathrm{~mm}$. broad near its base. The 8 ribs are very strongly marked, and are closely packed with small longitudinal spicules. The margin is 8-lobed, and the polyps are completely retractile, their walls thin and with 8 strongly marked rows of longitudinal and parallel spindles. The general conenchyma is packed with stouter spindles than those on the calyces. The tentacles are strongly retracted and do not appear to bear spicules.

The spicules are small spindles, closely warted throughout, rarely attaining a length of over $0.5 \mathrm{~mm}$. They are quite uniform, but vary in diameter, some being almost bar-like.

Color: Yellowish-brown, or tan color throughout.

Locality.-Station 4791; Cape Monati, Bering Island, N. $52^{\circ}$ W., 8.75 miles; 7.6-72 fathoms.

Type-specimen.-Cat. No. 30026, U.S.N.M.

This species resembles $C$. petersoni Kükenthal, ${ }^{2}$ but differs in the arrangement of spicules. 
CLAVULARIA EBURNEA Küikenthal.

Clavularia eburnea KüKentHaL, Japanische Alcyonaceen, 1906, p. 14.

A specimen secured by the U. S. Fisheries steamer Albatross is attached to an alcyonarian stem. The polyps attain but $7 \mathrm{~mm}$. in length. Otherwise they agree with the type.

Locality.-Station 4781 ; lat. $52^{\circ} 14^{\prime} \cdot 30^{\prime \prime}$ N.; long. $174^{\circ} 13^{\prime} 00^{\prime \prime}$ E.; 482 fathoms.

Type-locality.-Sea of Japan, 600-1,200 meters.

CLAVULARIA JAPONICA, new species.

Plate 1, figs. 1, 1a; plate 17, fig. 2.

Specimens in fragments. The largest piece is a straight stem or mother calyx, both ends lacking, $5.5 \mathrm{~cm}$. long, from which a number of irregularly placed secondary polyps arise. The main stem (or polyp) shows the even vertical lines of Telesto arborea, and is $1.7 \mathrm{~mm}$. in diameter throughout most of its length. The secondary calyces are arranged in an irregular spiral, two in a vertical series being separated by about $6 \mathrm{~mm}$. They grow at an angle of nearly 45 degrees from the stem, are cylindrical in form, $5 \mathrm{~mm}$. in length and $1.6 \mathrm{~mm}$. in diameter. They narrow gradually toward the base, and are truncate at their distal ends. The calycular surface is perfectly smooth, without corrugations, either longitudinal or transverse, except at distal end. Their walls are filled with vertical spindles covered with complex verrucæ which interlock with those of adjacent spicules, forming an even mosaic which it is hard to separate. These are embedded in the superficial layer of the calyces. Within this is another very thin and delicate layer of more slender spindles.

Spicules: These are modified spindles covered with short, variously branched and tuberculate processes, as described above.

Color: The entire-specimen is very light yellowish, or cream color. Locality.-Station 4888; Nomo Zaki, N. $57^{\circ}$ E., 16.5 miles; 71 fathoms (type). Station 4893; Ose Saki Light, N. $29^{\circ}$ E., 5.5 miles; 106-95 fathoms. Station 4894; Ose Saki Light, N. $41^{\circ}$ E., 5 miles; 95 fathoms.

Type-specimen.—Cat. No. 30039, U.S.N.M.

Family NEPHTHYIDÆ Verrill.

Colony with a usually sterile stem or trunk which bears a dendritic branching mass of polypiferous ramifications. Polyps not retractile.

\section{Genus LITHOPHYTUM Forskål.}

Nephthyidæ in which the polyps are arranged in lappets, and are without "Stutzbundeln" (Kükenthal). ${ }^{1}$ 


\section{IITHOPHYTUM ROSEUM, new species.}

Plate 1, figs. 3 , $3 a$; plate 17 , fig. 3.

Colony a compact lobulated mass $3.8 \mathrm{~cm}$. in height and with a greater diameter of $3.2 \mathrm{~cm}$. and a lesser diameter of $1.9 \mathrm{~cm}$. The main stem is very short, in the form of a flattened disk. The branches bear closely approximated nodules, oval when viewed from above, and with a larger diameter of $5 \mathrm{~mm}$. on the average; but they are also smaller in many cases. The branches are very short.

The individual calyces are entirely included, looking like those of Pocillopora. Their margins form a very slight elevated ring. They are about $1 \mathrm{~mm}$. broad, and the retracted polyps fill them level with the margin. The polyp walls bear eight longitudinal bands of pink spicules vertically arranged, not en chevron. The tentacles are short, broad, fringed, and apparently without spicules. The sides and under parts of the nodules bear warty protuberances which may be zooids, but are more likely young polyps.

Spicules: These are minute spindles, usually slender and with regularly disposed verrucæ. Sometimes they are stouter, tending to an oval shape, and, rarely, irregularly branched. Those in the polyp walls are pink, the others white.

Color: The stem is pallid, the retracted polyps and margins of the calyces are pinkish. The general cœenenchyma is whitish.

There are well developed ova in the bottoms of the calyx cavities.

Locality.-Station 5026; lat. $48^{\circ} 36^{\prime} 10^{\prime \prime}$ N.; long. $145^{\circ} 17^{\prime} 30^{\prime \prime} \mathrm{E}$.; 119 fathoms.

Type-specimen.-Cat. No. 30020, U.S.N.M.

\section{Genus DENDRONEPHTHYA Kükenthal.}

Nephthyidæ in which the polyps are usually in bundles, and in which the individual polyp is supported by several large spindles constituting the "Stutzbundeln" of German writers.

\section{DENDRONEPHTHYA SPLENDENS (Kiikenthal).}

Spongodes splendens KÜKENTHAL, Alcyonaceen von Ternate, 1896, p. 104.

Colony a beautifully symmetrical dendroid form $21.5 \mathrm{~cm}$. in height. The sterile stem is $10 \mathrm{~cm}$. high, wrinkled longitudinally throughout and with fine transverse rugosities on its distal end. The stem greatly resembles that of Ptilosarcus, and looks as if it wère inflatable. The main stem continues throughout the colony to near the distal end, where it forks. The branches are very numerous, short, and tend to an arrangement in whorls. They are sometimes strictly cylindrical and at others much flattened. The younger branches seem to be the round ones, the older flattened. The branches vary greatly in the extent of ramification, some of the larger ones being minia- 
tures of the colony from which they spring, bearing whorls of branchlets which again divide once or twice before the final bundles are reached. Other (younger) branches are very simple, in some cases bearing but one bundle of polyps. There are from three to eight or more polyps in the bundle.

The polyp and pedicel together measure $2.6 \mathrm{~mm}$. in height, on the average. The diameter of the polyp head is about $1.2 \mathrm{~mm}$. The calyx margin is surrounded by a crown of points, some of which project as much as $1.5 \mathrm{~mm}$. beyond the margin. - Their number is variable, but eight is quite common. Often two or three of these are the projecting points of spicules in the "Stutzbundeln." Another set of smaller spindles are longitudinally placed on the dorsal surfaces of the infolded tentacles.

Spicules: These are all spindles of various sizes, except stellate forms found in the stem. The largest spindles are on the under surfaces of the twigs, where they sometimes attain a length of $5 \mathrm{~mm}$. These large spindles are quite smooth under a low power, but show a surface closely set with sharp thorny points under a higher power. The stem walls contain sparsely scattered small spicules, cruciform, or irregularly stellate.

Color: The main stem, branches, and branchlets are pallid or whitish, the polyp heads are brownish-red.

Localities.-Station 4879; Oki Shima, S. $70^{\circ}$ W., 7.5 miles; 59 fathoms. Station 4893; Ose Saki Light, N. $29^{\circ}$ E., 5.5 miles; 106-95 fathoms. Station 4935; Sata Misaki Light, N. 58 E., 4.5 miles; 103 fathoms. Station 4936; Sata Misaki Light, N. $21^{\circ}$ E., 5.7 miles; 103 fathoms.

\section{DENDRONEPHTHYA ACAULIS Kiikenthal.}

Dendronephthya acaulis KÜKENTHAL, Japanische Alcyonaceen, 1906, p. 40.

The single specimen agrees well with the description and figures given by Kükenthal. I do not find, however, any of the small branched spicules illustrated in fig. $30, l$. c. Some of the long red spindles from the cœnenchyma of the branches attain a length of over $4 \mathrm{~mm}$.

Locality.-Station 5071; Ose Saki, S. 53.5 W., 2.6 miles; 57 fathoms.

General distribution.-Uragakanal, Japan, 150 meters. (Typelocality.)

Another fragmentary specimen from station 4879, near Oki Shima, 59 fathoms, is referred with doubt to this species. The crown of thorns is much more conspicuous than in the type described by Kükenthal, and the color is a bright red. 
DENDRONEPHTHYA MAGNACANTHA, new species.

Plate 2, figs. 2, $2 a$; plate 17, fig. 5 .

Colony small, but $2.1 \mathrm{~cm}$. in height and $1 \mathrm{~cm}$. in width. The stalk is $1.3 \mathrm{~cm}$. long, $3.5 \mathrm{~mm}$. in diameter, and is overlaid with large white, bent spindles vertically disposed. Some of these large spindles are as much as $4.5 \mathrm{~mm}$. in length.

The head consists of a dense mass of heavily spiculated polyps, each consisting of a distinct pedicel and polyp head. The stalk is abruptly bent just below the head so that the tentacles usually face downward. If straightened out, the whole would be about $6 \mathrm{~mm}$. in length; stalk or pedicel, being about $4 \mathrm{~mm}$. in height, and the head $2 \mathrm{~mm}$. high and 2.5 in diameter. The stalk bears on its convex surface a bundle of very strong white spicules about $3.5 \mathrm{~mm}$. long and 2 to 4 in number. The points of one or two of these large spicules usually project beyond the polyp head, and a few shorter spindles are longitudinally arranged on the sides of the stalk; but there are none on the ventral or concave side of the stalk or pedicel.

There is a very strong collaret of curved white spindles below the tentacle bases disposed in one or two circular rows. Often these spindles are bent at the middle so that the convex or upper side lies over the tentacle bases.

The tentacles are armed with bent longitudinal spindles, two of which are usually placed with their proximal ends divaricated (embracing the tentacle bases) and their distal ends approximated so as to form a point directed toward the center of the mass of infolded tentacles. This pair of spicules is usually a little over $1 \mathrm{~mm}$. in length, and is often reenforced by one to three smaller white spindles. The distal ends of the tentacles bear a number of comparatively small, even minute, spindles, irregularly disposed; but tending to be transversely placed near the tips of the tentacles and longitudinally arranged nearer the base.

Spicules: These are all densely tuberculate spindles, many of them unusually stout and heavy, showing white when in situ.

Color: The stalk is buffy-yellow, overlaid with white spindles. The polyps are chocolate-brown, overlaid with white spicules.

Locatities.-Station 4936; Sata Misaki Light, N. $21^{\circ}$ E., 5.7 miles; 103 fathoms (type). Station 5070; Ose Saki, S. $8^{\circ} \mathrm{W} ., 1.8$ miles; 108 fathoms.

Type-specimen.-Cat. No. 30090, U.S.N.M.

This species is very different from any other Dendronephthya in the collection, and is quite striking in color, the white spicules being well set off in contrast with the buffy and chocolate color of the stalks and polyp heads. 
DENDRONEPHTHYA NIGRIPES, new species.

Plate 2, figs. 1, 1a; plate 17, fig. 4 .

A number of colonies of this form were secured. A typical one is dentritic in its mode of branching and measures $3.5 \mathrm{~cm}$. in height from base of stem, and $2.2 \mathrm{~cm}$. in diameter. The main stem or stalk is terete in form, being $1 \mathrm{~cm}$. in diameter at its broadest part and narrowing both above and below, where it is longitudinally grooved so as to resemble the body of an Umbelluta. The main branches are flattened, very short, and soon subdivide into several very flat, leaf-like terminal twigs which bear polyps both on their edges and upper surfaces.

The root of the colony is peculiar, being divided into numerous soft, flattened, slender, ribbon-like processes which are almost black except at their distal ends, which are an orange-brown. The whole polypiferous part of the colony is very compactly arranged, so as to present an almost solid mass of polyps on its surface. The canals of the stem extend into the thin-walled root-like processes described above.

The individual polyp heads are borne on slender pedicels, the two together measuring but $2.2 \mathrm{~mm}$; the diameter of the pedicel being about $0.7 \mathrm{~mm}$., and of the head $1.1 \mathrm{~mm}$.

The spicules of the "Stutzbundeln" do not project conspicuously beyond the polyp head. Those in the polyp walls are arranged loosely en chevron, and are strongly marked, being red on a white or crcamy background, and the points of the chevron appear as marginal projections over the tentacle bases.

Each tentacle is provided with a pseudo-operculum much as in the Muriceidæ, each tentacle bearing on its dorsal surface two or more long slender spindles reaching nearly to the center of the mass of infolded tentacles, the whole forming a slender-rayed rosette, when viewed from above.

Spicules: These are all slender spindles with fine points over their entire surface, and often bent or sinuous. The largest are found on the under surfaces of the branchlets, where they attain a length of $4 \mathrm{~mm}$. and sometimes extend rib-like from the base to the polypiferous border of the branchlet. These large spicules are interspersed with much smaller but relatively somewhat stouter spindles. The spicules of the pedicels are usually white or yellowish longitudinal spindles, while those of the polyp heads are still smaller, and pinkish in color. The tentacular spindles are colorless.

Color: The peculiar root filaments are dark greenish-brown, almost black. The trunk and branches are white, sometimes tinged with pink. The calyces on some of the branches are white; but in most of them they are pinkish, sometimes tinged with yellowish.

$48702^{\circ}$-Proc.N.M.vol.43-12-2 
Locality.-Station 5074; Omai Saki Light, S. $37.5^{\circ}$ W., 6.4 miles; 47 fathoms.

Type-specimen.-Cat. No. 30091, U.S.N.M.

This species is not far from Spongodes pulchra Thomson and Henderson; but the stem and branch spicules are much larger, and the color of the root processes is so striking that it would be noted by any careful describer.

\section{DENDRONEPHTHYA OVIFORMIS, new species。}

\section{Plate 2, figs. 3 , $3 a$; plate 17 , fig. 6 .}

Colony ovoid in shape, $3.1 \mathrm{~cm}$. in height, and $2.9 \mathrm{~cm}$. in diameter. The stem is short and stout, being $1.2 \mathrm{~cm}$. in height and terminating below in a small greenish mass of rootlets. The branches are flattened and frilled plates emplanted in two whorls, the lower of which projects outward and downward (thereby concealing most of the stem in side view), while the upper extends outward and upward. Each is divided into short flattened branchlets which bear the polyp bundles. Each bundle consists of from three to eight polyps, a common number being four. The branches of the upper whorl bear branchlets on their surfaces; these support bundles of polyps which fill the upper rounded surface of the colony.

The pedicels are usually quite short and stout for this genus, the pedicel and polyp head together not averaging more than $1.8 \mathrm{~mm}$. in length. The pedicel wall is ornamented with curved red spindles usually diagonally placed and sparsely distributed on the front and sides, usually being transverse on the latter. The backs are strengthened by very large yellowish or pink spindles which are slightly curved and attain a length of $5 \mathrm{~mm}$., projecting as much as $1.7 \mathrm{~mm}$. above the polyp head. The upper parts of the polyps bear small red spindles arranged en chevron. Often several large spicüles form a bundle with their points appressed and projecting nearly $2 \mathrm{~mm}$. beyond the margin. Besides these there are a number of spindle ends forming a marginal crown, much as in Acanthogorgia.

The dorsal surfaces of the infolded tentacles are armed with a row of curved spiny spindles, placed transversely and curving to fit the rounded surface of the tentacle.

Spicules: The spicules of the polyps, twigs and branches are all spindles, the larger ones being comparatively smooth, but bearing very fine spines on their surfaces. They are usually more or less curved, sometimes S-shaped. The bare parts of the stem bear many minute oval or stellate spicules, and sometimes crosses.

Color: The stem, branches, and pedicels are light yellow. The polyps are white, but this color is largely concealed by the pink or scarlet spicules. The root is dark greenish. 
Locality.-Station 4888; Nomo Zaki, N. 57 ${ }^{\circ}$ E., 16.5 miles; 71 fathoms.

Type-specimen.-Cat. No. 30041, U.S.N.M.

\section{Genus PARASPONGODES Kükenthal.}

Nephthyidæ, resembling Dendronephthya in structure, but having polyps without supporting bundles of spicules. Polyps either single or united in bundles.

\section{PARASPONGODES STRIATA Thomson and Henderson.}

Paraspongodes striata Thomson and Henderson, Ceylon Pearl Oyster Report, 1905, p. 277.

Colony arborescent, $6.1 \mathrm{~cm}$. high and $4.5 \mathrm{~cm}$. broad. The barren part of the stem is $2.2 \mathrm{~cm}$. long and $1.8 \mathrm{~cm}$. broad, narrowing above and below. Its proximal end is covered with numerous slender, soft, root-like filaments of a dark greenish-brown color. The branches are in two whorls, those in the lower being contiguous and confluent basally; some branchlets being directed downward and others upward. Except near the bases of the larger branches the branches are all round in section. Branchings up to the fifth order are attained, all branches being very distinctly and regularly wrinkled transversely, resembling trachæary tissue. The polyp bundles are small, as are the individual polyps. The latter are so matted together that it is hard to determine the number in a bundle, probably the average being six to eight. The pedicel and polyp head together are about $2 \mathrm{~mm}$. long, and the head is but slightly broader than the pedicel, the diameter being about $1 \mathrm{~mm}$.

The polyps are terete in form, like grains of wheat. The walls are armed with spindles arranged roughly en chevron, and some of them project over the margin. The largest spicules are those in the twigs bearing the bundles, some of these attaining $5 \mathrm{~mm}$. in length. All of these spindles are slender, sinuous or bent, and their surface is covered with closely set spiny points. There are few spicules projecting much beyond the margin. The spicules in the walls of the stem are intricately branched crosses of minute size.

Spicules: These are all spindles of various sizes, but of the type described, and crosses which are profusely branched.

Color: The stem and branches are grayish-white, the polyps dull brown. The rootlets are dull greenish-brown.

Locality.-Station 5071; Ose Saki, S. 53.5 W., 2.6 miles; 57 fathoms. Type-locality.-Gulf of Manaar.

\section{Family ALCYONIDE Verrill (emended).}

Colonial Alcyonacea in which the polyps are retractile. The proximal part of the stem is usually devoid of polyps, the cœnenchyma is 
thick, and the spicules abundant. The endodermal canals are not in direct communication with each other.

Genus ALCYONIUM Linnæus (emended by Kükenthal).

Colonies of various forms. Polyps retractile, as are the calyces when evident. Canal system not divided distinctly into inner and outer layers.

ALCYONIUM KÜKENTHALI, new species.

Plate 3, figs. 1, $1 a$; plate 18, fig. 1.

Colony an exceedingly irregular lobulated mass, apparently broken from a much larger specimen. Most of the sterile portion of the stem is missing. The part of the colony present is $8.2 \mathrm{~cm}$. high and 5.3 $\mathrm{cm}$. wide. The opposite flat surfaces seem to have been the upper and lower sides of a flattened lobular branch of the original colony. The lower surface is largely devoid of polyps, and appears to be the naked surface of the very broad leshy, spongy, main stem. The upper surface and lateral edges of the mass are almost covered with rounded lobes of various sizes averaging about $1.5 \mathrm{~cm}$. broad and $1.1 \mathrm{~cm}$. high. Each is born on a very short, thick, fleshy branch from the main stem. A section of a large branch shows a spongy tissue traversed by very numerous comparatively small canals, with no spicules in the walls betweon them. The peripheral canals show externally as longitudinal ridges.

The polyps are thickly scattered over the lobes, and are completely retractile, although many of them are fairly well expanded in the specimen described, reaching a height of $2 \mathrm{~mm}$. Their diameter is a little over $1 \mathrm{~mm}$. The polyp walls are ornamented with eight vertical bands of tuberculate spindles, each band consisting of several irregular rows longitudinally placed and extending to the polyp margin. There are a few scattered spindles between these rows. The tentacles are rather long and deeply fringed. They appear to be destitute of spindles.

Spicules: These are very sparse in this species, being confined merely to the rows of spindles just described on the polyp bodies. There are none on the surface of the branches, and they also appear to be absent in the spongy interior. They are nearly all small or minute slender spindles, with well marked verrucæ. There are also a very few minute cruciform spicules and rudely stellate and branched forms.

Color: The whole specimen is a pallid light brown. Another specimen in the same bottle, apparently the same species, has the polyps all completely retracted, and the nodules subdivided or broken up into smaller groups of polyps.

Locality.-Station 5016; lat. $46^{\circ} 44^{\prime} 30^{\prime \prime}$ N.; long. $143^{\circ} 45^{\prime}$ E.; 64 fathoms. 
Type-specimen.-Cat. No. 30036, U.S.N.M.

Named in honor of Prof. W. Kükenthal, of Breslau, whose admirable work on Alcyonaria has added so much to our knowledge of that group.

\section{ALCYONIUM GRACILLIMUM Kükenthal.}

Alcyonium gracillimum KüKENTHAL, Japanische Alcyonaceen, 1906, p. 34.

A number of specimens in the collection agree well with the original description and figures of this species. The colonies are growing on soft, fleshy tubes which are presumably worm tubes.

The polyps are retractile, but in expansion they raise the surrounding tissue into short calyces with pinkish, warty spindles arranged vertically. The lower part of the exposed polyp has 8 double rows of slightly pinkish spindles arranged en chevron and extending upward into 8 longitudinal bands. The basal parts of the tentacles bear transverse spicules.

The spicules are small stout spindles, with comparatively large verrucæ.

Color: Light yellowish-brown.

Localities.-Station 5005; lat. $46^{\circ} 04^{\prime} 40^{\prime \prime} \mathrm{N}$.; long. $142^{\circ} 27^{\prime} 30^{\prime \prime} \mathrm{E}$; $42-43$ fathoms. Station 5006; lat. $46^{\circ} 04^{\prime} \mathrm{N}$.; long. $142^{\circ} 29^{\prime} \mathrm{E}$.; $42-43$ fathoms. Station 5007; lat. $46^{\circ} 03^{\prime}$ N.; long. $142^{\circ} 31^{\prime}$ E.; 42 fathoms.

General distribution.-The type-locality is Misaki, Sagami Bay, Japan.

Genus NIDALIA Gray (emended by Kükenthal).

Colony simple. The sterile and polypiferous portions sharply differentiated. The delicate polyps retractile within nonretractile calyces. Zooids absent. Spicules warty rods and spindles. ${ }^{1}$

IIDALIA RUBRA (Brundin).

Bellonella rubra Brundin, Alcyonarien des zoologischen Museums in Upsala, 1896, p. 6.

Nidalia rubra KüKENTHAL, Japanische Alcyonarien, 1906, p. 22.

Four specimens from station 4807 agree very well with Kükenthal's description and figures. They are lighter red than those figured by that author; but one, the smallest, is brighter than the others, and is more nearly the color represented by Külkenthal.

Height of colony $3.6 \mathrm{~cm}$. Stem $1.4 \mathrm{~cm}$. long. The diameter of the stem is $7 \mathrm{~mm}$., and of the polypiferous part of the colony $13 \mathrm{~mm}$. The details of the polyps, spiculation, etc., agree well with the description referred to.

- 1 This definition is a condensed and abridged transiation of the one given by Külenthal, Japanische Alcyonaceen, 1906, p. 19. 
Locality.-Station 4807 ; Cape Tsiuka, S. $58^{\circ}$ W., 10.3 miles; $44-47$ fathoms. Station 4815; Nuigata Light, S. $25^{\circ}$ E., 21.5 miles; 70 fathoms.

General distribution.-Korea Straits and Tsugaru Straits, Japan (Brundin). Misaki, Sagami Bay, Japan (Kükenthal).

NIDALIA GRACILIS, new species.

Plate 3, figs. 3, 3a; plate 18, fig. 2.

Colony unbranched, slender, $8.2 \mathrm{~cm}$. in height. The stem is very short, being but $1.5 \mathrm{~cm}$. long with a diameter of $8 \mathrm{~mm}$., while that of the widest part of the colony is $6 \mathrm{~mm}$.

The stem is forked below and spreads out in lobular processes which are adherent to the two sides of a flat shell, and is both longitudinally and transversely corrugated.

The polyps are more sparsely distributed than in $N$. rubra, often being as much as $3 \mathrm{~mm}$. apart, and scattered over all sides of the rodlike polypiferous part of the colony.

The individual calyces attain a height of about $2 \mathrm{~mm}$. and a diameter of $2.5 \mathrm{~mm}$. at the base. The summit is 8-lobed and the walls contain numerous rodlike spicules which appear like granules under low magnification. These spicules are very small, terete, densely tuberculate spindles.

The polyps are retractile, but many of them are fairly well expanded in the type. The distal parts are expanded so as to appear as if borne on pedicels. The polyp extends $2.5 \mathrm{~mm}$. above the calyx margin, and about $2 \mathrm{~mm}$. of this is included in the tentacular mass, which is about $1.5 \mathrm{~mm}$. in diameter. The polyp walls have a few transversely disposed red spindles at the bottom, eight double rows arranged en chevron above these, vertical spindles on the distal part forming vertical bands extending to the tentacle bases. The distal parts of the tentacles show no spicules.

Spicules: These are of two main types. 1. Rather slender but highly tuberculate spindles found in the polyp walls and the general cœnenchyma; 2. Very short, oval, much tuberculated spicules which sometimes intergrade with round, or even stellate, forms.

Color: The stem is yellowish-brown; the general cœnenchyma and sides of calyces rather dull red; the margins of the calyces yellow; and the polyp bodies, below the tentacle bases, yellow, while the polyp head is white.

Locality.-Station 4946; Okiko Jima, N. $31^{\circ}$ E., 4 miles; 39 fathoms. Type-specimen.-Cat. No. 30101, U.S.N.M.

\section{Genus BELLONELLA Gray.}

Colony unbranched, rod-like or conical. Calyces largely included, verruciform. Spicules often stars, crosses, and other branched forms. 


\section{BELLONELLA FLAVA, new species.}

Plate 2, figs. 4, 4a; plate 18, fig. 3 .

Colony a single, thick, unbranched, curved stem, $4.4 \mathrm{~cm}$. in height, round, with a greatest diameter of $1.1 \mathrm{~cm}$. The basal nonpolypiferous part is like a turgid collar around the base, $4.5 \mathrm{~mm}$. high and $12 \mathrm{~mm}$. in diameter. The polyp-bearing part is somewhat terete in side view, with a rounded end. The polyps are emplanted on all sides on low rounded eminences averaging about $3 \mathrm{~mm}$. from center to center. The axis of the stem is traversed by large cylindrical cavities, or conspicuous longitudinal canals. The intervals between the rounded eminences, or verrucæ, and the verrucæ themselves are marked by a mesh of wrinkles which checker the whole surface, the wrinkles being mainly longitudinal and transverse. The calyces are marked by eight strong longitudinal lobes or corrugations, ending at the margin which closes over the retracted polyp. The calyces near the margin are $1.5 \mathrm{~mm}$. in diameter; and the infolded margins are lobed, and yellowish in color.

There is a well-marked collaret of small red spindles in several transverse rows. The tentacle bases are armed with similar spindles arranged en chevron, and the distal portions of their dorsal surfaces bear three or four rows of similar spindles longitudinally disposed, forming a rosette when the retracted polyp is viewed from above.

Spicules: These are all small, the prevailing types being double heads and doutle crosses. Sometimes the double heads are flattened so as to resemble the "collar-button" spicules of the genus Bebryce. There are a few relatively large slender spindles with sparsely distributed thorny points on their surfaces; these are white and yellow.

Color: General surface dull, light yellow, brighter on the calyces, polyp spicules bright carmine red.

Locality.-Station 4894; Ose Saki Light, N. $41^{\circ}$ E., 5 miles; 95 fathoms.

\section{Type-specimen.-Cat. No. 30089, U.S.N.M.}

This species differs from Nidatia rubra (Brundin) ${ }^{1}$ not only in color, but also in the spicules, particularly those of the tentacles.

\section{Genus ANTHOMASTUS Verrill.}

Colony mushroom-shaped, with a thick rounded head on a short round sterile stem. Polyps large and completely retractile. Zooids present, between the polyps. 


\section{ANTHOMASTUS JAPONICUS, new species.}

Plate 3, figs. 2, $2 a$; plate 18, fig. 4 .

Capitulum round, $4.1 \mathrm{~cm}$. in diameter. Total height of colony 7 $\mathrm{cm}$., the sterile stem being about $6 \mathrm{~cm}$. in height. The capitulum has its outer edge folded downward so that its edge is $2.2 \mathrm{~cm}$. below its central and highest point. The whole colony is in the shape of a typical toadstool. The stem of this specimen differs from the others, and all other species of the genus thus far described, in having a sharp constriction about $2 \mathrm{~cm}$. from its distal end, below which the stem is produced into a tongue-shaped termination, rounded and even at the end, like many pennatulids. The other specimens end in ragged. lobular edges, where the stem has been torn from its support, the one described being the only one that is certainly complete.

The stem measures $15 \mathrm{~mm}$. in greatest diameter. The polyps are about 45 in number, of which about 30 are situated on the edge of the capitulum. The upper surface is much less thickly emplanted. Smaller polyps appear irregularly among the larger ones, the latter measuring $12 \mathrm{~mm}$. to base of tentacles, the tentacles themselves reaching $7 \mathrm{~mm}$. in length. The polyp bodies increase in diameter from below upwards, being in some cases $5 \mathrm{~mm}$. in diameter just below the tentacular bases. The body cavities extend directly to join the stem cavity.

Siphonozooids are densely crowded over the entire upper surface of the capitulum between the polyps, giving it a granular appearance. Under a low power of the microscope they appear as closely packed, rounded, or cone-shaped verrucæ with a pit in the center. Upon dissection these siphonozooids are seen to contain ova.

Spicules: These are almost all needle-like or bar-like forms, nearly smooth, or at least not with pronounced verrucæ, as described in other species of the genus. In the polyps there are a number of minute, smooth, barlike spicules, also minute crosses, stars, and double stars. All spicules smaller than usual in the genus.

Color: The colony is dark red, the polyps somewhat darker. The stem is red above, fading to a grayish-red below. Two specimens from station 5050 were much more brilliant in color than the type, the capitulum and polyps being bright scarlet.

Localities.-Station 4976; Shio Misaki Light, N. $59^{\circ}$ E., 6.4 miles; 545-544 fathoms. Station 5043; $42^{\circ} 10^{\prime} 20^{\prime \prime} \mathrm{N}$., $142^{\circ} 15^{\prime} 20^{\prime \prime} \mathrm{E}$.; 330-309 fathoms (type). Station 5050; Kinka San Light, N. $78^{\circ}$ W., 25.7 miles; 266 fathoms.

Type-specimen.-Cat. No. 30038, U.S.N.M.

A specimen from station 4976 has a triangular capitulum with large polyps at the corners and a greater diameter of $3.2 \mathrm{~cm}$. One of the polyps is $2 \mathrm{~cm}$. long to the tentacles, and the tentacles are 
$1.8 \mathrm{~cm}$. long. The polyp bodies are strongly ridged longitudinally, the ridges extending along the basal part of the tentacles. The zooids have their summits surrounded by circles of small spicules. The color is bright scarlet, the stem being dull grayish. Although this specimen differs considerably from the others, it is doubtless specifically identical with them.

\section{Family SIPHONOGORGID E Kölliker (emended by Kükenthal.)}

Siphonogorgidæ KüKentHal, Japanische Alcyonaceen, 1906, p. 69.

Alcyonacea with the general appearance of Gorgonacea. Cœnenchyma hard. Polyps borne only on the ends of ultimate branchlets and retractile within calyces, with their body cavities lengthened into canals which traverse the interior of the branches and contain but four mesenteries. ${ }^{1}$

\section{Genus SIPHONOGORGIA Kölliker.}

Being the only genus of the family Siphonogorgidæ, its definition is the same as that given above. It has been abbreviated by Kükenthal. ${ }^{2}$ The following is the substance of his definition:

Sarcosoma with little connective tissue except in the canals, which are continuous with the body cavities of the polyps. Calyces with slightly developed opercula.

\section{SIPHONOGORGIA SPLENDENS Kiikenthal.}

Siphonogorgia splendens KüKENTHAL, Japanische Alcyonaceen, 1906, p. 80.

A specimen from station 4935 agrees very well with the original description of this species. The colony is $5.5 \mathrm{~cm}$. long; stem quite thick and longitudinally wrinkled, and breaks up $2.3 \mathrm{~cm}$. from its base into three unequal branches. All of the larger branches bear small ultimate branchlets scattered throughout their length; but the distal branchlets are crowded at their ends with bright red polyps.

The calyces vary greatly in size, $3 \mathrm{~mm}$. being a common height. Their walls are supported by strong, usually vertical spicules which are heavily tuberculated and end in a series of blunt, irregular marginal points. They do not project much beyond the calyx margin, however.

The polyps are retractile to their strongly marked collar, which is composed of three or more rows of transverse spindles. The tentacles are armed with a pseudo-operculum much like that in the Muriceidæ, and as figured by Kükenthal.

The spicules are very strongly tuberculate spindles, sometime reaching $5 \mathrm{~mm}$. in length.

1 This definition and one for the genus Siphonogorgia are condensed and abbreviated translations from the original by Kükenthal.

2 Japanische Alcyonaceen, p. 69. 
Color: The stem and branches are very light buffy, the polyps bright red, nearly scarlet.

Localities.-Station 4815; Niigata Light, S. $25^{\circ}$ E., 21.5 miles; 70 fathoms. Station 4894; Ose Saki Light, N. $41^{\circ}$ E., 5 miles; 95 fathoms. Station 4934 ; Sata Misaki Light, N. $77.5^{\circ}$ E., 7 miles; 152-103 fathoms. Station 4935; Sata Misaki Light, N. $58^{\circ}$ E., 4.5 miles; 103 fathoms.

Type-locality.-China Sea.

Another specimen, from station 4935, is much larger, $13 \mathrm{~cm}$. long, and shows the general mode of branching to be irregularly dendritic.

\section{Order PENNATULACEA.}

Colonial forms not permanently attached to the bottom, or to other objects. Stem with an axial cavity which is often longitudinally subdivided by thin partitions, and contains an axis cylinder. Spicules needle-like or bar-like, never warty. Both polyps and siphonozooids are generally present. ${ }^{1}$

\section{Family PENNATULID无 Kölliker.}

Axis and pinnæ present, the latter large, and without calcareous, ray-like bodies. Colony pinnate. Zooids on ventral and lateral sides of the rachis.

Genus PTILOSARCUS Gray.

Calyx with two marginal teeth. Polyps without spicules.

PTILOSARCUS BREVICAULIS, new species.

Plate 4, figs. 3, $3 a$.

A typical specimen from station 4876, preserved in formalin, measures $18 \mathrm{~cm}$. in total length, of which the stem constitutes $5.2 \mathrm{~cm}$. The stem is spindle-formed, being greatly inflated a little above its middle, and greatly constricted just below the rachis and at its lower end. Greatest diameter of stem $2 \mathrm{~cm}$. Diameter just below the pinnæ $6 \mathrm{~mm}$.

This character seems constant in all the specimens secured, and is doubtless due partly to contraction; but nevertheless it is much more pronounced than in $P$. quadrangularis.

The stem is strongly furrowed longitudinally. Rachis very much inflated, and nearly round in section, with the exception of the dorsal and ventral grooves. Its greatest dorso-ventral diameter is $2.5 \mathrm{~cm}$. and the diameter from side to side is almost exactly the same. There

\footnotetext{
1 Hawaiian Alcyonaria, Nutting, 1908, p. 557. The definitions of families and genera of the Pennatulacea aro mostly adapted from those given by Kölliker in his Anatomisch-Systematische Beschreibung der Alcyonaria, Die Pennatuliden, 1872; and the report on the Challenger Pennatulacea, by the same auther.
} 
are 33 pairs of leaves, and their ventral edges are straight, one of the longest having this edge $3 \mathrm{~cm}$. long. The polypiferous border is not nearly so extensively convoluted as in $P$. quadrangularis or Leioptitum undulatum, and is about $6 \mathrm{~cm}$. long and rather regularly curved from the ventral end to where it joins the rachis dorsally.

The calyces are in two or three rows on the borders of the leaves. They are small, usually with two opposite marginal points or teeth. In places there appears to be but one wavy row of calyces. The marginal teeth are filled with needle-like spicules, and these descend in bands above the partitions between the leaf chambers that are the continuations of the body cavities of the polyps. These spicules are not confined to a narrow band immediately below the polypiferous border, but are thinly and irregularly scattered along the partitions clear to the base of the leaf. The calyces measure about $2 \mathrm{~mm}$. in height, along the side of the edge of the leaf, and are less than $1 \mathrm{~mm}$. in diameter. They are closely appressed to each other along the border, leaving but their margins elevated above the surface.

The polyps are small, white, and appear to be without spicules.

The zooids are in two very broad turgid bands along the entire length of the rachis, with a narrow median furrow between them, much narrower than in $P$. quadrangularis. Unlike that species, the zooids in the present form extend around between the leaves to the termination of the latter on the ventral surface, entirely covering the spaces between the leaves. The zooids are minute rounded points emplanted thickly, but not contiguous. Each is surrounded by a fence of spicules.

The spicules are small, smooth, sharp needles, characteristic of the family.

Color: The colony is light brownish-yellow. The polypiferous borders of leaves and end of stem somewhat darker. Leaves translucent.

Locatities.-Station 4807; Cape Tsiuka, S. $58^{\circ} \mathrm{W} ., 10.3$ miles; 44-47 fathoms. Station 4808 ; Cape Tsiuka, S. $61^{\circ} \mathrm{W} ., 10.6$ miles; 47 fathoms. Station 4876; Oki Shima, S. $29^{\circ}$ W., 5.3 miles; 59 fathoms (type).

Type-specimen.-Cat. No. 30013, U.S.N.M.

Genus PENNATULA Linnæus.

The rachis bears zooids on the ventral side only. Spicules scattered over the entire surface, not being confined to the leaf borders.

PENNATULA ACULEATA Danielssen.

Pennatula aculeata Danielssen, Forh. Vid. Sel. Christiania, 1858, p. 25.

A few small specimens from station 4766 are referred with some doubt to this widely distributed and variable species. They may be young colonies.

Length of colony $7.1 \mathrm{~cm}$.; stem $3.4 \mathrm{~cm}$. The stem swelling is long, occupying $1.7 \mathrm{~cm}$. The leaves are in 12 pairs, directed forward, 
lanceolate, slender, opaque. There are five or six polyps to the leaf, one of which forms the leaf termination. Calyces slender, obconical, separate, sometimes $4 \mathrm{~mm}$. long to the end of the teeth, with eight very slender acute teeth or spines projecting $2 \mathrm{~mm}$. beyond the margin.

Zooids: The ventral zooids are very numerous on ventral surface, except on the middle band. Lateral zooids in rows of four or six between leaf bases, really dorsal in position.

Spicules: These are-long sharp needles, reddish- or yellowish-white in color.

Color: The colony is grayish-yellow, tinged on leaves with red.

Locality.-Station 4766; Koniuji Island, S. $22.5^{\circ}$ W., 27 miles; 1,766 fathoms.

General distribution.-Greatest depth reported, 1255 fathoms. New England coasts. Common on eastern shores of the Atlantic and in the North Sea. Californian coast (Nutting).

PENNATULA SULCATA Kölliker.

Pennatula sulcata KöLliker, Challenger Report, the Pennatulidæ, 1880, p. 8.

?Pennatula fimbriata Herklots, teste H. Balss, Zool. Anzeiger, vol. 34, 1909, p. 428.

Several specimens in the collection agree quite closely with Kölliker's description of this species. In some of these there is a more abrupt swelling on the upper part of the stem than is figured by that writer, and in some the rachis is not twice as long as the stem.

The length of a large specimen is $12.5 \mathrm{~cm}$. The longest pinna is $2.3 \mathrm{~cm}$. in length and its width is $7 \mathrm{~mm}$. There are 20 to 24 polyps on the fully developed leaves, and the calyces are armed with eight points composed of bundles of spicules. The polyps have rather long tentacles, for this genus; and these are deeply fringed, and bear a few very delicate spicules on their dorsal surfaces.

The spicules are colorless, stout needles, borne on the rachis, pinnæ, and calyces. The proximal portion of the stem has the surface filled with minute oval disks.

The zooids are very numerous, there being two very broad, turgid bands on the ventral surface, and these bands are divided by a deep groove. There are also narrow bands of zooids between the bases of the leaves.

Localities.-Station 4934; Sata Misaki Light, N. 77.5 E., 7 miles; 152-103 fathoms. Station 5056; Ose Saki, N. 37 $7^{\circ}$ E., 5 miles; 258 fathoms. Station 5092; Joga Shima Light, N. $19^{\circ}$ W., 3.5 miles; 70 fathoms.

Doctor Balss identifies this species with $P$. fimbriata Herklots, but does not give any description. The matter of specific differentiation is so far from being reduced to any actual standard, and the views regarding specific characters are so varied, that the writer hesitates 
about reducing an accepted name to the ranks of synonymy unless the evidence is presented.

\section{PENNATULA MURRAYI Kölliker.}

Pennaiula murrayi KöLIIKen, Challenger Report, the Pennatulidæ, 1880, p. 5.

Total length of colony $12 \mathrm{~cm}$. Stem $4 \mathrm{~cm}$. long, with a sharply defined terete swelling just below the rudimentary pinnæ. The leaves are slender, 22 pairs, lanceolate, $10 \mathrm{~mm}$. long and $3 \mathrm{~mm}$. broad. The calyces are 9 to each leaf, when the latter is fully developed, tubular, much exserted, $2 \mathrm{~mm}$. long, $1 \mathrm{~mm}$. broad; not expanding at the margin, but contracting slightly. The marginal points are much broken in the specimen described, but they do not appear to be regularly 8 in number. The spicules are longitudinally placed on the calyx walls, and are usually nearly parallel. In the leaves the spicules are crisscrossed. The polyps are yellowish, probably yellow in life.

The zooids differ greatly in size, one or two of the ventral series being very large, looking like rudimentary polyps opposite each leaf base. Continuous with these is a broken row or patch of lateral zooids, between the bases of the leaves and running around to the dorsal surface, which, however, they do not invade. The zooids are conical in shape and surrounded by a group of spicules with their distal ends approximated, forming the apex of the cone.

The spicules are red and yellow needles, characteristic of the pennatulids, the longest being about $1.5 \mathrm{~cm}$. long. They are found in the stem, rachis, leaves, and calyces.

Color: The prevailing color is red. The leaves, ventral surface of rachis and basal end of stem, rather dull yellow, as are the polyps. The specimen agrees well with the original description.

Locality.-Station 4934; Sata Misaki Light, N. 77.5 E., 7 miles; 152-103 fathoms.

General distribution.-The type was found by the Challenger southeast of Ceram, west of New Guinea, 29 fathoms. Maldives, 43 fathoms (Hickson).

This specimen differs from the original description in the length of leaves, which Kölliker describes as $17 \mathrm{~mm}$. long, instead of $10 \mathrm{~mm}$., as in the specimen described above. In detail, however, the description tallies well.

PENNATULA PENDULA Thomson and Henderson.

Pennatula pendula Thomson and Henderson, Alcyonaria of the Indian Ocean; I, Alcyonaria of the Deep Sea, 1906, p. 118.

The colony is scarlet, total length $10.5 \mathrm{~cm}$. The stem to rudimentary leaves, $3.1 \mathrm{~cm}$., slender, swollen at about its middle and with a moderately distended end bulb. Its greatest diameter is $2.1 \mathrm{~mm}$., and its least diameter, below rachis, $1 \mathrm{~mm}$. There are 15 pairs of leaves from the first that show developed calyces. Leaves triangular 
in shape, a well developed one being $1.5 \mathrm{~cm}$. in length and $4 \mathrm{~mm}$. broad at the base. The leaves are closely approximated, forming a dense tuft or clump at the end of the colony. They overlap on the dorsal surface, being alternate in position. There are eight calyces in a single row on a fully developed leaf, directed outward, forward, and upward.

The individual calyces are tubular in shape, $2.5 \mathrm{~mm}$. high and 1.9 $\mathrm{mm}$. broad at the margin. The margin is ornamented with 8 sharp points 'composed of a bundle of needle-like spindles with their distal ends approximated. The proximal ends of the same bundles form 8 rather obscure vertical ridges on the calyx walls. Inside of these bundles there are a number of shorter horizontal needles on the upper parts of the walls, and others irregularly disposed on other parts of the walls. Some of the points project as much as $1.5 \mathrm{~mm}$. above the margin.

The polyps are white, strongly retracted, and seem to have a few small red spindles on the tentacles.

The zooids are small, inconspicuous and situated in broken rows, sometimes patches, in the sides of the rachis and between the leaves, there being 12 to 15 in a row. Each zooid shows as a white papilla, minute and surrounded by a fence of spicules.

The dorsal and ventral surfaces of the rachis seem devoid of zooids, although one of the rows may end in a patch of 5 or 6 on the ventrolateral side.

The whole rachis is covered with red spicules, laid on haphazard. The axis extends nearly to the end of the end bulb.

The spicules are all slender, smooth needles, attaining a length of $2 \mathrm{~mm}$.

The color of the colony as a whole is a bright scarlet. The stem is creamy white, and the polyps white.

Localities.-Station 4958; Mizimoko Shima Light, N. $26^{\circ}$ W., 29.3 miles; 405 fathoms. Station 4959; Mizimoko Shima Light, N. $23^{\circ}$ W., 28.5 miles; 405-578 fathoms.

Type-locality.-Indian Ocean.

This species is very near to $P$. sanguinea Nutting, which has 6 polyps to the leaf, and the leaves less closely approximated.

PENNATULA NARESI Kölliker.

Pennaiula naresi KöLliker, Challenger Report, the Pennatulacea, 1880, p. 2.

Colony $40 \mathrm{~cm}$. long, stem $8.5 \mathrm{~cm}$. long, with a strong deeply corrugated enlargement about $1 \mathrm{~cm}$. below the rachis, and a clubshaped end bulb. The rachis is quadrate in section, being laterally compressed. Its dorso-ventral diameter is $5 \mathrm{~mm}$. and from side to side it is $3 \mathrm{~mm}$. There are about 35 pairs of leaves, which are not closely approximated. The individual leaves are sickle-shaped, and 
are often bent backward, outward and inward so that their distal ends almost meet. This is not constant, however, some of the leaves taking an opposite direction, their ends almost meeting on the ventral side of the rachis.

The fully developed leaves are about $3 \mathrm{~cm}$. long, measured around the polypiferous border, and $1.7 \mathrm{~cm}$. directly across from base to tip. Their greatest diameter is $9 \mathrm{~mm}$.

The calyces are curiously distributed, there being a group of 4 or 5 on the proximal end of the pinnule, the others being placed in a zigzag row (sometimes double) along the border, there being 28 or 30 in a full grown leaf. The individual calyces are somewhat hourglass-shaped, expanding at top and bottom, about $3 \mathrm{~mm}$. high to base of points, and having a marginal diameter of $2 \mathrm{~mm}$. There is a crown of points, the typical number being 8 , around the margin. These points are often very unequal in size, and each is composed of a bundle of needle-like yellow spicules with their distal ends approximated. These points occasionally extend $2.5 \mathrm{~mm}$. beyond the margin. Similar spicules are vertically disposed in the calyx walls, tending to form 8 longitudinal bands. A few small red spindles are on the basal parts of the calyx walls.

The spicules of the leaves are smaller and red, criss-crossed and mingled with the yellow ones near the polypiferous zone. The polyps are white, with a few red, curved spicules lying lengthwise on the dorsal surfaces of the tentacles.

The zooids are very numerous and conspicuous, forming yellow bands along the ventro-lateral surfaces, the bands broadening into triangular patches between the bases of the leaves and extending in a line of smaller zooids along between the leaf bases. The zooids in the ventro-lateral bands are the larger, and are surrounded by clumps of yellow spindles.

The spicules are red and yellow, needle-like, smooth spindles, giving their color to the colony, and attaining about $2 \mathrm{~mm}$. in length.

Color: The leaves, distal portion of the stem, and those parts of the rachis not occupied by zooids are rather dull scarlet. The polyps and zooid zones are bright yellow. The lower part of the stem is yellowish.

Localities.-Station 4960; Misimoko Shima Light, N. $19^{\circ}$ W., 30.5 miles; 578 fathoms. Station 4973 ; Shio Misaki Light, N. $82^{\circ}$ E., 12.5 miles; 600 fathoms.

Type-locality.-South of Yeddo, Japan; 345 fathoms.

This is one of the most brilliant of all known pennatulids, and must be a gorgeous object when symmetrically expanded. 
PENNATULA LONGISTYLA, new species.

Plate 4, figs. 2, $2 a$.

Colony $9.8 \mathrm{~cm}$. in length and $2.1 \mathrm{~cm}$. wide. The stem is $4.8 \mathrm{~cm}$. long, with a slight, not abrupt, swelling $3 \mathrm{~mm}$. in diameter $1 \mathrm{~cm}$. from the rachis. There is no evident end-bulb. The rachis bears 20 pairs of leaves, which are narrow and straight for this genus, and end proximally in a short twisted pedicel, beyond which the leaf is remarkábly uniform in width. The length of a fully developed leaf is $1.6 \mathrm{~cm}$. and its diameter $3 \mathrm{~mm}$.

There are five normal polyps on each leaf, and a rudimentary one on its proximal end.

The calyces lie closely set along the leaf border in a single series overlapping each other and almost parallel to the border. Their length is hard to determine, but appears to be about $3 \mathrm{~mm}$. The calyces are narrow, tubular, and a little over $1 \mathrm{~mm}$. in diameter. The margin bears 8 slender, acute, not very conspicuous points composed usually of but one or two spicules. The polyps are white, with long tentacles fringed with long papillæ which often appear capitate.

The zooids are much as in Pennatula sulcata as to distribution, but much larger and more conspicuous. There are two broad bands occupying the whole ventral surface of the rachis except a narrow median groove. The zooids are densely crowded and papilliform, longer than broad, the papillæ being directed toward the distal end of the rachis. These bands extend to and cover the rounded top of the rachis, and broaden between the leaf bases. The lateral zooids are in close set lines extending around below each leaf base to the dorsal surface. They are smaller than those on the ventral bands.

The spicules are small needles, light brownish-yellow in color, on the rachis pinnules and calyces; and shorter, more bar-like needles in the stem.

The color of the colony in general is light yellowish-brown, the stem being lighter than the rachis.

Locality.-Station 4815; Niigata Light, S. $25^{\circ}$ E., 21.5 miles; 70 fathoms.

Type-specimen.-Cat. No. 30095, U.S.N.M.

\section{PENNATULA RUBESCENS, new species.}

Plate 5, figs. 1, $1 a$.

Colony $12.7 \mathrm{~cm}$. in length, of which the stem is $3.5 \mathrm{~cm}$. The stem has a very slight swelling a little below the rudimentary leaves, and a very slender termination. The greatest diameter of the stem is $2.6 \mathrm{~mm}$, and the least, below the swelling, $1.2 \mathrm{~mm}$.

There are about 40 pairs of leaves, counting the rudimentary ones. They are very slender triangles $1.2 \mathrm{~cm}$. in length and $3 \mathrm{~mm}$. 
in diameter. There are 12 calyces in a single row on each fully developed leaf.

The calyces are tubular, enlarging somewhat at the distal end and with margins armed with 8 distinct sharp points, each point containing a number of red spicules with their distal ends approximated. A number of other spicules, mostly colorless, are embedded in the calyx walls and usually vertical in position. The surface of the leaf contains numerous spicules which are criss-crossed. Ova can be seen in the transparent cœnenchyma of the leaf. The calyces are $2 \mathrm{~mm}$. high and a little more than $1 \mathrm{~mm}$. broad at their margins.

The ventral mid-line of the rachis is deeply grooved.

The zooids differ greatly in size. There is a group of 3 or 4 very large ones on the ventral surface, opposite the base of each leaf and, continuous with these, a patch of 8 or 10 smaller ones extending toward, but not reaching, the dorsal surface. All of the zooids are conical in shape, their walls being beset with red spicules which have their distal ends converging to a point. The ventral surface of the rachis is beset with red spicules criss-crossed and intermixed with colorless ones. The same is true of the dorsal surface.

The spicules are as described above. All are red or colorless needles, rather small. There are few if any on the stem.

Color: The colony is grayish, except that the calyces are bordered with light carmine red, and the rachis tinged with red. This color is also seen in the swelling on the stem. The specimens are much injured and dirty. Originally they must have been very daintily colored.

Locality.-Station 5071; Ose Saki, S. 53.5 W., 2.6 miles; 57 fathoms.

Type-specimen.-Cat. No. 30047, U.S.N.M.

PENNATULA BREVIPENNA, new species.

Plate 4, figs. 1, $1 a$.

Colony very slender; leaves very short, so that the whole affair approaches a virgularian in general appearance. Total length, 35.7 $\mathrm{cm}$. Stem to rudimentary leaves $13 \mathrm{~cm}$., very slender, with a not very well marked swelling the middle of which is $5.3 \mathrm{~cm}$. from the end; and a slender end bulb. Diameter at swelling $3 \mathrm{~mm}$. Least diameter, between swelling and leaves, $1.3 \mathrm{~mm}$.

There are about 65 pairs of leaves, rather distant in proximal part of rachis, and closely crowded on distal part. They are a lengthened triangle in shape, $9 \mathrm{~mm}$. long, in a straight line, and $4 \mathrm{~mm}$. broad at the base. They are alternate in position, and their bases overlap each other on the mid-dorsal surface of the rachis. There are 10 calyces arranged in a single row on each fully developed leaf. The 48702 -Proc.N.M.vol.43-12-3 
individual calyx is a double cone or spindle in shape, the distal end being much longer and more pointed than the proximal; or they might be regarded as flask-shaped, about $2.5 \mathrm{~mm}$. long and $1.5 \mathrm{~mm}$. broad at the basal swelling. The calyx spicules do not project much beyond the margin, but form 8 well-defined vertical bands of small delicate spicules, much less conspicuous than other species of this genus in the collection.

Zooids: There is a very large zooid on the ventro-lateral surface just at the edge of the base of each leaf, consisting of an elevated ring surrounding a relatively enormous aperture. From this a triple row of much smaller zooids passes upward and dorsally along the rachis between the leaf bases, but does not reach the dorsal surface. This row finally becomes a single row of zooids, and near its end is a very small but evident calyx, showing polyp tentacles; a feature not seen before. The zooids have minute spicules in their walls.

Spicules: These are all relatively small colorless needles.

Color: Light grayish-brown throughout, darkening to reddish-brown on end of stem.

Locality.-Station 4948; O Shima Light, N. 11 ${ }^{\circ}$ E., 12 miles; 65 fathoms.

Type-specimen.-Cat. No. 30048, U.S.N.M.

\section{PENNATULA INERMIS, new species.}

Plate 5, fig. 3.

Total length of colony, $43 \mathrm{~cm}$; stem, $7 \mathrm{~cm}$. There is a spindleshaped swelling with a greatest diameter of $5 \mathrm{~mm}$., $4.6 \mathrm{~cm}$. from the end, which is longitudinally grooved in the preserved specimen, and an end bulb in the shape of a flattened lobe.

There are about 50 pairs of leaves which are rather distant for this group, there being a space of about $3 \mathrm{~mm}$. between adjacent leaves. The individual leaf is strictly triangular in shape, the edges all being nearly straight. The lower edge is $14 \mathrm{~mm}$. in length, the polypiferous border $12 \mathrm{~mm}$., and the attached base $9 \mathrm{~mm}$. The leaf is fleshy and opaque.

The calyces are in two rows, although there appear to be three in places, about 28 to the row. They are tubular in form, and so thin that the polyps appear to be nude. They are $2 \mathrm{~mm}$. in length, the margin being faintly evident as a slightly thickened collar around the polyp. There are 8 dimly outlined longitudinal corrugations. The calyces and dorsal surfaces of the tentacles are encrusted with very short bar-like or oval disk-like spicules.

Zooids: There is a band of ventral zooids on either side of a wellmarked ventral groove on the rachis, but quite distant from it. The individual zooids are minute and there are about three rows in each band. The lateral zooids are larger finger-like bodies in rows run- 
ning dorsally and distally from the end of the polypiferous border of each leaf, 6 or 8 in each row, diminishing in size dorsally.

Spicules: Those in the calyces and polyps are different from any others that I know of in these positions in the genus Pennatula. They are oval, or very short bar-like forms, very minute, seen with difficulty and apt to be entirely overlooked. They form streaks on the dorsal surfaces of the tentacles and encrust the calycine walls.

Color: The colony is very light yellow, almost cream-colored. The end of stem is reddish-brown.

Locatities.-Station 4876; Oki Shima, S. $29^{\circ}$ W., 5.3 miles; 59 fathoms (type). ?Station 5072; Omai Saki Light, S. $37^{\circ}$ W., 11.7 miles; 284-148 fathoms.

Type-specimen.-Cat. No. 30049, U.S.N.M.

A specimen from the station 5072 has apparently been dried and is therefore hard to identify. It has the general form of this species, however, and the very characteristic form of the spicules described above. The leaf borders are carmine red.

This species bears some resemblance to Pennatula splendens Thomson and Henderson ${ }^{1}$ especially in the form of spicules.

\section{Genus PTEROIDES Herklots.}

Pennatulidæ with well-developed leaves, each of which is supported by thorn-like bony stays radiating outward from its base. Zooids are found on the pinnæ, but not on the rachis.

\section{PTEROIDES SAGAMIENSE Moroff.}

Pteroides sagamiense Moroff, Studien über Octocorallien, Zoologische Jahrbücher, Abth. Syst. Geogr. Biol. Thiere, vol. 17, Heft 3, 1902, p. 366, pl. 18, figs. 11-12.

There are several specimens in the collection that agree very closely with Moroff's description of his "specimen No. 2," and especially in the details of his figure 11 , plate 18 .

The colony is very fleshy, the stem thick and straight, and the leaves straight, and directed upward and forward. On the lower part of the rachis the pinnæ close over and conceal its dorsal surface completely. Their outer edges are reenforced by strong spinelike spicules in a series parallel to the leaf border. Other similar spine-like spicules are radiated from the bases of the leaves toward the polypiferous zone. The ventral surface of the rachis is thick and turgid, and shows a distinct median furrow.

The color of the colony (in alcohol) is livid or whitish with large areas of slaty gray. In one specimen this color covers the dorsal surface of the rachis. In others it simply shows through a whitish integument.

Locality.-Shimizu, Suruga, shore. 
Type-locality.-Sagami Bay, Japan. Type collected by Doctor Haberer.

\section{Genus HALISCEPTRUM Herklots.}

Pennatulidæ which bear well-developed leaves devoid of spicules.

\section{HALISCEPTRUM GUSTAVIANUM Herklots.}

Halisceptrum gustavianum HerkLots, Nederl. Tijdskr. v. Dierkunde, vol. 1, 1863, p. 31 .

Colony $13.6 \mathrm{~cm}$. in height; stem, to rudimentary leaves, $3.3 \mathrm{~cm}$., $6 \mathrm{~mm}$. thick with hardly any differentiated end bulb. The rudimentary leaves are very numerous, occupying $3.2 \mathrm{~cm}$. of the rachis, diminishing to a mere slender band below.

The pinnæ are very numerous, closely appressed. The polyps are in several rows on each leaf, very numerous, small, acorn-shaped, the tentacles forming the smaller ends of the acorns. The leaves are convoluted on their polypiferous borders.

The zooids are very numerous on the ventral side of the rachis on either side of a small, sharply distinguished median groove. There also appear to be numerous lateral and dorsal zooids, and a dorsal groove.

The color of the colony is very light brownish, or "pallid" throughout.

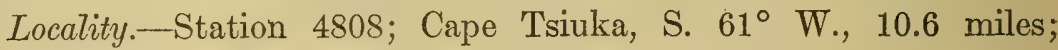
47 fathoms.

Type-locality.-Amoy, China.

\section{HALISCEPTRUM CYSTIFERUM Nutting.}

Halisceptrum cystiferum Nutring, Alcyonaria of the Californian Coast, 1909, p. 698.

Colony $13.8 \mathrm{~cm}$. long. Both the proximal and distal ends of the specimen are missing, leaving $9 \mathrm{~cm}$. of the rachis and part of the stem. The number of polyps to the leaf ( 4 or 5), as well as their size and shape, agrees well with the original description.

The end of the stem being missing it is impossible to determine whether the characteristic structure, that is, the bladder-like end bulb, is present in the specimen or not.

Locality.-Station 5015 ; lat. $46^{\circ} 44^{\prime}$ N.; long. $144^{\circ} 02^{\prime}$ F.; 510 fathoms.

Type-locality.-Off Point Pinos, California, 394-609 fathoms.

HALISCEPTRUM ALBUM, new species.

Plate 5, figs. 2, $2 a$.

There are two specimens in the collection, one consisting of the proximal and the other of the distal part of colonies of this species, and the following description is a composite of the two, as they very nearly supplement each other. 
Combined length $31 \mathrm{~cm}$. Stem to rudimentary leaves $5 \mathrm{~cm}$., with a spindle-shaped swelling with its widest part $3.5 \mathrm{~cm}$. from its end, $8 \mathrm{~mm}$. in diameter. There is no distinct end bulb, but the end is curved. The axis is hard, stony, and quadrangular in section, reaching to within $12 \mathrm{~mm}$. of the end of the stem, hard and unyielding to the end. Part of the fleshy part is stripped from the axis in both specimens, but is still attached by the fleshy coenenchyma. There are approximately 50 pairs of leaves, but some of them are so matted together that their inumber is hard to determine.

The individual leaves are broad, and their borders so frilled that their true shape is hard to determine. They are broadly triangular, with a much curved and frilled border. Length of fully developed leaf $1.8 \mathrm{~cm}$.; greatest width $2 \mathrm{~cm}$. The polyps are arranged in single rows at the two ends of the leaf, and in two or three rows throughout the median portions of the polypiferous border. They are so soft and matted together that it is almost impossible to count them without separating them one by one; but there are from 45 to 50 in a fully developed leaf.

The individual calyx is slender, tubular, gradually enlarging toward the margin, where it ends in eight rounded finger-like lobes which might be mistaken for contracted tentacles. These lobes are continued downward, narrowing as they go, into faintly defined perpendicular ridges running the entire length of the calyx wall. The calyces are about $3 \mathrm{~mm}$. in length and $2.8 \mathrm{~mm}$. in diameter at the margin. The polyps are well retracted, only their massed tentacles showing above the calyx. The walls of the leaves are translucent, and the septa and mesenterial filaments can be seen to the bottom or stem part of the leaves.

Zooids: The ventral zooids are numerous, in two broken series, bordering an impressed line along the mid-ventral surface. From these rows the lateral zooids run in single rows around between the leaf bases, but do not extend to the dorsal surface. This is bare of zooids, and seems to correspond to the ventral surface of Ptilosarcus, for instance.

Spicules: There are no spicules in leaves, polyps or cœnenchyma of rachis. Near the end bulb of the stem, however, there are numerous minute calcareous particles embedded in the cœnenchyma. They are exceedingly irregular, and secn to have no characteristic shape.

Color: The entire colony-is very pale yellowish-brown.

Localities.-Station 4817; Niigata Light, S. $29^{\circ}$ E., 18 miles; 61 fathoms (distal part of the colony), type. Station 4876; Oki Shima, S. $29^{\circ}$ W., 5.3 miles; 59 fathoms (proximal part of colony).

Type-specimen.-Cat. No. 30092, U.S.N.M. 
Although the presence of spicules would seem to indicate that this species should be placed in the genus Pennatula, the general appearance, and absence of spicules from nearly the entire colony seems to justify assigning it to Halisceptrum.

\section{Family VIRGULARIDAE.}

Colony slender; pinnæ short, often reduced to a band and without a plate of spine-like spicules at their bases.

\section{VIRGULARIÁ, species ?}

A specimen belonging apparently, to this genus, but in too poor condition, and too fragmentary to admit of satisfactory description, was sccured at station 4947; Okiko Jima, N. 17 E., 4.4 miles; 51 fathoms.

\section{Genus BALTICINA Gray.}

Stem thick; rachis very long in proportion to stem; pinnæ reduced to band-like rows of calyces; spicules in the tentacles of the polyps.

BALTICINA FINMARCHICA (Sars).

Virgularia finmarchica SARS, Fauna Lit. Norvegiæ, vol. 2, 1856, p. 68.

Colony $152 \mathrm{~cm}$. in length; stem $53 \mathrm{~cm}$; end bulb and swelling confluent and $15 \mathrm{~cm}$. long and with a greatest diameter of $2.8 \mathrm{~cm}$. and least diameter of $8 \mathrm{~mm}$. Stem and rachis dorso-ventrally flattened. Greatest diameter of rachis, with leaf bands, $1.7 \mathrm{~cm}$.; lesser diameter, at same point, $1.2 \mathrm{~cm}$. There are 237 polyp bands, with 11 or 12 polyps to each band. Exposed portion of bands $5 \mathrm{~mm}$. broad. The bands are oblique and closely appressed, meeting on dorsal surface of rachis. The ventral surface of the rachis is entirely bare.

The calyces of a given row are adherent to each other at their margins. Each has two spine-like or horn-like processes projecting from the two sides of the exposed surface. These, as well as the calyx walls, are leathery, without any external evidence of spicules. The calyces decrease in size from the dorsal to the ventral surface of the rachis, and are packed full of ova.

Zooids: There is a row of rounded verruciform zooids between adjacent leaves. Each row spreads into a patch of scattered zooids on the ventro-lateral surface between the leaf endings. The row and patch combined contain about 15 zooids.

Spicules: There are no spicules in calyces or polyps; neither have I found them in other parts of the colony, except a few amorphous calcareous particles.

Localities.-Station 4983; Benkei Mizaki Light, S. $2^{\circ}$ E., 12 miles; 428 fathoms. Station 4998 ; lat. $47^{\circ} 39^{\prime} 10^{\prime \prime}$ N.; long. $141^{\circ} 31^{\prime} 40^{\prime \prime}$ E.; 66 fathoms. Station 5047; Kinka San Light, N. 69.5 11.6 miles; 107 fathoms. 


\section{Type-locality.-Oxfjord, Finmark.}

In one specimen the polyps are sometimes 15 in a row; otherwise the specimen agrees with the description given above.

This species appears to the writer to be identical with the one called Verrillia blakei Stearns, and redescribed by the writer in his Alcyonaria of the Californian Coast, 1909, page 706, where a discussion of the synonymy will be found.

These specimens agree so closely with the figures and descriptions of Balticina finmarchica (Sars) that I assign them to that species in spite of the apparent absence of spicules from the tentacles.

BALTICINA PACIFICA Nutting.

Plate 6, fig. 4.

Balticina pacifica NutTing, Alcyonaria of the Californian coast, 1909, p. 704.

Colony $47 \mathrm{~cm}$. in length, of which the stem is $15 \mathrm{~cm}$. In some specimens there is a greatly distended swelling on the stem; in one case $7 \mathrm{~mm}$. thick and over $5 \mathrm{~cm}$. long, while the least diameter of the stem below the rachis is but $1.7 \mathrm{~mm}$. In the specimen described, however, the swelling is less distended than the end bulb, although this may be partially due to shrinking.

There are about 94 rows of polyps, 2 or 3 to a row, on each side. In the lower part of the rachis there is but one polyp to represent each row; higher up there is one large outer one and a rudimentary inner one; still higher a third, innermost one appears, and in the fully developed rows there are three of about equal size. The rows are quite oblique and are all on the latero-ventral surface, leaving the whole dorsal surface bare.

Each calyx has two sharp spines projecting from its outer margin, the spines being filled with needlelike spicules which also extend to other exposed parts of the calyx walls. The inner margin of the calyx is not differentiated from the polyp body, and lies snugly against the stem. . The height of a typical calyx is about $3 \mathrm{~mm}$., and the diameter is $2 \mathrm{~mm}$. The tentacles have their dorsal surfaces covered with very numerous barlike spicules in many parallel rows. In one specimen the body walls of the polyps are greatly distended, and form sacklike transparent protuberances on the inner, or stem side, of the polyp.

Zooids: The zooids are very few and inconspicuous and irregular in distribution, appearing as whitish dots sparsely distributed on the ventral surface. The lateral zooids are in an irregular row or patch of 5 or 6 between adjacent polyp rows.

Spicules: These are numerous, being quite abundant in both polyps and calyces. They appear to be wanting elsewhere. The axis cylinder in the rachis is round in section, and smooth. 
Color: The polyps are reddish-brown and the rachis light yellow. The end bulb is reddish-brown.

Localities.-Station 4768 ; lat. $54^{\circ} 20^{\prime} 30^{\prime \prime}$ N.; long. $179^{\circ} 09^{\prime} 30^{\prime \prime} \mathrm{E}$.; 764 fathoms. Station 4792; Cape Monati, Bering Island, N. $50^{\circ} \mathrm{W}$., 8.2 miles; 72 fathoms. Station 4985; Kamoi Misaki Light, N. $17^{\circ} \mathrm{E}$., 15.2 miles; 224 fathoms. The specimen described came from this station. Station 5031; lat. $44^{\circ} 04^{\prime} 00^{\prime \prime} \mathrm{N}$.; long. $145^{\circ} 32^{\prime} 00^{\prime \prime} \mathrm{E}$.; 86 fathoms.

Specimens from station 4792 had the tentacles expanded, and their dorsal surfaces were marked by clear-cut white lines of silvery spicules. General distribution.-The type-locality is off the Californian coast.

\section{BALTICINA CALIFORNICA (Motoff).}

Pavonaria californica Mororf, Studien über Octocorallien, Zoologische Jahrbücher, Abth. Syst. Geogr. Biol. Thiere, ser. 5, vol. 17, Heft 3, 1902, p. 393.

Length $97.5 \mathrm{~cm}$., stem $32 \mathrm{~cm}$. There are 115 polyp rows, polyps 3 to 5 in each row. There are spicules in the two teeth on the margin of each calyx. The tentacles are without spicules, the characteristic feature of this species.

The polyps are reddish-brown.

Localities.-Station 4984; Benkei Mizaki Light, S. $3^{\circ}$ W., 15 miles; 248-224 fathoms. Station 4986; Benkei Mizaki Light, N. $35^{\circ}$ E., 15 miles; 172 fathoms.

General distribution.-The type-specimens were presumably from the Californian coast, although this fact is not noted in the original description.

This species may be the same as the last, but the absence of tentacular spicules is a character which, if constant, would be a good specific character. Both specimens in this collection have parasitic or symbiotic astrophytons attached to them.

\section{Genus HALIPTERIS Kölliker, modified by Jüngersen. ${ }^{1}$}

Calyces with 2 to 4 teeth; zooids lateral.

\section{HALIPTERIS CHRISTII (Koren and Danielssen).}

Tirgularia christii KonEN and Danielssen, Nyt Magazin for Naturvidenskaberne, vol. 5,1848 , p. 269

Halipteris christii KöLLIKER, Anatomisch-Systematische Beschreibung der Alcyonaria, I, Die Pennatuliden, 1872, p. 249.

Length of colony $12 \mathrm{~cm}$. Stem $3.2 \mathrm{~cm}$., very slender, with no evident swelling, and a very slender and inconspicuous end bulb. The calyces are arranged in a single zigzag row, or double row,

1 This genus is here placed in the family Virgularidæ, instead of the Protoptilidæ, on account of the argument presented by Jüngersen in Danish Ingolf Expedition, vol. 5, 1904, p. 45. This writer, however, Institutes the family Pavonaridæ, in which he includes Halipteris. He finds that the genus Stichoptilum of Grieg represents merely the young stages of Halipteris. 
according to interpretation. The well developed calyces are further from the mid-dorsal line than the developing calyces, which lie in such a way that each developing calyx is supported as it were on its lower and outer side by a full-grown one. A well developed calyx is $2.3 \mathrm{~mm}$. high on its outer side, and reduced to almost nothing on the side next the rachis; and about $1.5 \mathrm{~mm}$. in diameter. Its walls are filled with vertical needles which project in conspicuous points beyond the margin. Some of them have two very large points and others four smaller ones. Still others have no regular points. On the proximal part of the rachis there is but a single row of calyces on each side. Many of the developing calyces have their distal portions pointed, the spicules closing over the apertures by meeting at the apex of a cone.

The polyp tentacles have each a broad band of several rows of vertically disposed barlike spicules which are very conspicuous.

Zooids: The zooids are smooth, brown, yellowish bodies, quite distant from each other. The plan of distribution seems to be, one on the inner and dorsal, and another on the latero-ventral side of each calyx base; but this order is not constant, although there are generally two to each calyx.

Spicules: These are of two general types. The ordinary needlelike form in the calyces and general surface of the rachis, and the barlike spicules seen in the tentacles.

Color: The stem is very light straw color; the calyces have a faint pinkish or purplish tinge due to the showing through of the dark brown bodies of the polyps. The tentacles are whitish.

Locality.-Station 4984; Benkei Mizaki Light, S. $3^{\circ}$ W., 15 miles; 248-224 fathoms.

General distribution.-Type-locality, Lofoten, Norway: Also reported from Tynemouth, England.

The specimens in the coliection agree in essentials with the definition of the genus Stichoptilum Grieg, which Jüngersen regards as the young of Halipteris. From the latter author's discussion, I regard this specimen as the young of Halipteris christii.

\section{Family. UMBELLULID丑.}

Polyps very large, without calyces and borne in a cluster at the end of a very long and slender stem.

Genus UMBELLULA Lamarck.

Being the only genus in the family, it bears the characters of the Umbellulidæ. 


\section{UMBELLULA MAGNIFLORA Kölliker.}

Umbellula magniflora Kölliker, Challenger Reports, the Pennatulida, 1880, p. 24.

Five fine specimens in an excellent state of preservation and all evidently of the same species, afford an interesting study in the variations in measurements of this beautiful Umbellula. The series was arranged with reference to the size of polyps.

\begin{tabular}{|c|c|c|c|c|c|}
\hline $\begin{array}{c}\text { Specimen } \\
\text { No. }\end{array}$ & $\begin{array}{c}\text { Total } \\
\text { length. }\end{array}$ & $\begin{array}{c}\text { Rachis and } \\
\text { polyps. }\end{array}$ & Polyps. & Tentacles. & $\begin{array}{c}\text { Number of } \\
\text { polyps. }\end{array}$ \\
\hline & $C m$. & $C m$. & $C m$. & $C m$. & \\
1 & 51 & 9.3 & 4.9 & 2.8 & 21 \\
2 & 83 & 5.0 & 3.8 & Absent. & 10 \\
3 & 53 & 5.3 & 2.9 & 1.6 & 9 \\
4 & 54 & 5.0 & 2.4 & 1.2 & 8 \\
5 & 80 & 5.5 & 2.3 & 1.5 & 9 \\
\hline
\end{tabular}

No. 1 is a distinct pinkish salmon in color, except some of the polyp bodies which are a reddish brown. This color is superficial, however, and is easily rubbed off.

Nos. 3,4 , and 5 are almost white, with a slight pinkish cast, tending to a light salmon in the pinnules.

These measurements seem to show that there is no relation between the age of the colony, as indicated by the number of polyps and the length of the stalk. There seems, however, to be a general relation between the size of the polyps and the number on a colony.

Aside from being much larger, the polyps of No. 1 are much more fully expanded than those of the other specimens.

The following additional facts were noted regarding specimen No. 1:

There is a distinct swelling above the end bulb, $1.2 \mathrm{~cm}$. in diameter, the least diameter of the stem being $2 \mathrm{~mm}$. The polyps are fully extended and increase from $2.5 \mathrm{~mm}$. in diameter near the distal end to $6 \mathrm{~mm}$. near the base. The polyp walls are smooth and semipellucid, the mesenteries showing plainly through them. There are a number of shallow corrugations disposed in an annular manner around the upper part of the body walls.

There are about 34 pairs of long, filiform pinnules in each tentacle.

The zooids are very numerous, covering the rachis where not occupied by the polyps. Those on the rachis do not regularly have tentacles and appear to the naked eye as rounded granules. Under magnification they show a central mouth. On the lower part of the stalk they are smaller, but each has a long unbranched tentacle. Although rubbed off in places, they were undoubtedly originally emplanted on all parts of the stalk.

There were no spicules found in these specimens. 
Locality.-Station 4975; Shio Misaki Light, N. $49^{\circ}$ E., 7 miles; 712 to 545 fathoms.

General distribution.-The type-locality is in the South Sea, east of Kerguelen Island, 1,600 fathoms. Hawaiian region, 216-438 fathoms (Nutting).

\section{UMBELLULA CARPENTERI Kölliker.}

Umbellula carpenteri Kölurker, Challenger Reports, the Pennatulida, 1880, p. 23.

Two specimens, both female with ova, were secured at station $5080 ; 505$ fathoms.

The larger specimen is $75 \mathrm{~cm}$. in length, the head measuring $5 \mathrm{~cm}$., polyp bodies $2.4 \mathrm{~cm}$. long, and the tentacles $1.6 \mathrm{~cm}$. The swelling above the end bulb is $6 \mathrm{~mm}$. wide, and about $4.3 \mathrm{~cm}$. long. The stem is very slender, its least diameter being $1.2 \mathrm{~mm}$.

There are 8 polyps, almost white, with 8 longitudinal corrugations. The tentacles are smooth, their dorsal surfaces colorless, the rest of the tentacles and pinnules being very light salmon. The pinnules are about 30 in number.

The zooids are numerous and many of them bear single tentacles, usually unbranched. There are very few calcareous particles, even in the end bulb.

The smaller specimen also has 8 polyps and agrees more nearly with Kölliker's measurements. The details are much the same as in the other specimen.

Localities.-Station 5080; Omai Saki Light, N. $23.5^{\circ}$ E., 28 miles; 505 fathoms. Specimens collected at station 5015, lat. $46^{\circ} 44^{\prime} \mathrm{N}$.; long. $144^{\circ} 02^{\prime} \mathrm{E}$., 510 fathoms, are apparently of this species.

General distribution.-Type-locality, South Polar Sea, southwest of Australia, 1,975 and 1,950 fathoms. Hawaiian region, 595 to 1,124 fathoms (Nutting).

UMBELLULA ELOISA, new species.

Plate 6, figs. $3,3 a$.

Total length of colony, $73 \mathrm{~cm}$. Head, including enlargement of stem, $7 \mathrm{~cm}$. The lower part of the stem has no very evident end bulb, but terminates in a bent, club-shaped end, which is continuous with the stem swelling. The greatest diameter of the swelling is $6 \mathrm{~mm}$; the least diameter of the stem, $2 \mathrm{~mm}$. The beginning of the enlargement of the rachis to the base of the polyps is $1.9 \mathrm{~cm}$., the diameter of the rachis just below the polyp bases being $1.5 \mathrm{~cm}$. The polyps are very large, 14 in number, 7 in an outer whorl and 7 within. The length of the largest polyp to tentacle bases is 2.4 $\mathrm{cm}$. The tentacles are much shrunken and are $1.7 \mathrm{~cm}$. in length, making the whole length of tentacles and polyp $4.1 \mathrm{~cm}$. This is the largest alcyonoid polyp that the writer has seen. 
The polyp bodies are not regularly corrugated as in many species of the genus, but have a tough leathery surface, with a few irregular wrinkles due to shrinking. Polyps of a dull purplish color below, livid above, this color extending along the greater part of the dorsal surface. The tentacles are erect, more rigid than usual, their inner and lateral surfaces being deep purplish-brown, as are the distal parts all around. The pinnules are about 24 on each side, their dorsal sides livid, the rest purplish-brown. Their bases are overlaid with comparatively large, bar-like colorless spicules, most of which are longitudinally disposed. Some of them are over $1 \mathrm{~mm}$. in length.

Very large, bar-like spicules, some of them $2.5 \mathrm{~mm}$. long, are embedded in the tough cœnenchyma of the tentacle bases, a group of several being longitudinally disposed along the proximal dorsal part of each tentacle and reaching to the pinnules.

The general integument of the polyps, rachis, and stem is filled with minute calcareous bodies of an oval or biscuit shape, which are too small to be seen with the unaided eye.

The zooids are very numerous, but small and inconspicuous. They surround the polyp bases and extend downward in ill-defined triangular patches nearly to the bottom of the swelling below the rachis. They are also scattered between the polyps on the rachis; but the polyps are so compactly crowded on the rachis that there is but little room left for zooids.

The whole head is so symmetrical that one can not tell without dissection whether there is a terminal polyp or not.

Spicules: These have been described. Some of those on the tentacle bases are by far the largest that I find mentioned as found in the Umbellulidæ, except in $U$. durissima Kölliker.

Color: The stem is grayish, end-swelling and bulb yellowishbrown; basal parts of polyps reddish-brown or dull purplish, distal parts of bodies and dorsum of tentacles to near tips livid. The rest of the tentacles and most of the pinnules are rich purplish-brown, almost a wine color.

Locality.-Station 4973; Shio Misaki Light, N. $82^{\circ}$ E., 12.5 miles; 600 fathoms.

Type-specimen.-Cat. No. 30009, U.S.N.M.

This is the finest Umbellula that the writer has seen. It may possibly be $U$. durissima Kölliker, which it resembles in spiculation and color; but it can not be placed here until intergrading specimens are found. 


\section{Family KOPHOBELEMNONIDE.}

Polyps in distinct rows or series on both sides of the rachis, large, sessile, and not provided with calyces. Rachis elongated in comparison with the Umbellulidæ.

Genus KOPHOBELEMNON Absjornsen (modified).

Polyps not symmetrically in pairs; spicules abundant.

KOPHOBELEMNON FERRUGINEUM Kölliker.

Kophobelemnon ferrugineum KöLLiKer, Challenger Reports, the Pennatulida, 1880, p. 16.

Colony $9.5 \mathrm{~cm}$. in length, of which the stem is $4.7 \mathrm{~cm}$. The end bulb is evident and swollen in the form of a clavate knob. Greatest diameter of stem, near distal end, $6 \mathrm{~mm}$; between end bulb and swelling, $4.5 \mathrm{~mm}$; end bulb, $7 \mathrm{~mm}$. The rachis has a pointed termination.

The polyps are large, partially retractile, irregularly distributed on the dorsal and lateral surfaces of the rachis, very much shrunken and distorted. The polyp bodies are almost entirely included or retracted in the specimen. Visible wall, $3 \mathrm{~mm}$. long, $4 \mathrm{~mm}$. in diameter and rudely corrugated vertically. The tentacles are $5 \mathrm{~mm}$. long, each having a dorsal ridge or sharply defined longitudinal crest, packed with needles which are both longitudinal and criss-crossed, showing as a white band and sending branches to dorsal surface of each pinnule.

There are about 18 pinnules on each side. The sides of the tentacles, below pinnules, bear transverse needles, but the mid-ventral line of the tentacles is almost free.

Zooids: These are closely and evenly packed over the entire surface of the rachis which is not occupied by polyps. They are comparatively large, conical, with their distal ends pointed outward and upward, their walls filled with needles usually tending to a vertical position.

Color: The colony is grayish-brown, the inner sides of the tentacles dusky brown.

Spicules: The entire surface is packed with needles.

Locality.-Station 4990; lat. $43^{\circ} 40^{\prime}$ N.; long. $140^{\circ} 58^{\prime}$ E.; 200 fathoms.

Type-locality. - South of Yeddo, Japan, 345 fathoms.

The specimen agrees fairly well with Kölliker's exceedingly brief description. 
KOPHOBELEMNON HISPIDUM, new species.

Plate 6, figs. 2, $2 a$.

The colony is $7.8 \mathrm{~cm}$. in length. The stalk is short and not sharply distinguished from the rachis, broadened immediately below the polyps, where it is $1.5 \mathrm{~cm}$. wide in front view, but only $4 \mathrm{~mm}$. thick from front to back. Its proximal end is broadened and truncated, the leathery integument with which it is covered being tucked in at the end as if partly involuted. The narrowest part of the stem is immediately above the end bulb, where it is round and $4.5 \mathrm{~mm}$. in diameter, and its surface is covered with numerous small needles, giving it a hispid appearance, which suggests its specific name.

The polyps are three in number, almost in line above the flattened rachis, the middle one, however, being distinctly higher than the lateral ones, which are on the same level. They are much shrunken and distorted, the bodies being narrower below and broadening to $5 \mathrm{~mm}$. at the tentacle bases. Height to tentacles $1.2 \mathrm{~cm}$. Tentacles $1.6 \mathrm{~cm}$. long, laterally compressed. There are 16 pinnules which are very slender, round in section, and covered on back and sides with a close felting of longitudinal spicules so closely packed as to completely cover the surface. The tentacles are also covered on all sides with these slender needles.

The zooids are low, verruciform bodies, often showing a central aperture. They are regularly distributed on all exposed parts of the stem and rachis. Their walls are filled with the same needle-like spicules that cover the entire colony. They are vertically arranged in the walls of the zooids, with their points converging toward the margins.

Spicules: These are all slender needles, or rather slender rods with rounded ends. They are seldom over $1 \mathrm{~mm}$. in length.

Color: The colony is gray, excepting the tentacles, which have a brownish tinge.

Localities.-Station 4956; Mizunoko Shima Light, N. $22^{\circ}$ W., 33 miles; 720 fathoms (type). Station 4977; Shio Misaki Light, N. $65^{\circ}$ E., 7 miles; 544 fathoms.

Type-specimen.-Cat. No. 30094, U.S.N.M.

This form greatly resembles one that the writer has described as Umbellula, sp. ? ${ }^{1}$

Family ANTHOPTILID $\approx$ Kölliker.

Pennatulids bearing free, sessile polyps. Calyces absent. 


\section{Genus ANTHOPTILUM Kölliker.}

Polyps large, disposed in numerous short rows. Rachis without a streak of undereloped polyps below the developed ones. Zooids may be on all sides of the rachis. Spicules, if present, confined to the proximal end of stalk.

\section{ANTHOPTILUM MURRAYI KöHliker.}

Anthoptilum murrayi KöLliker, Challenger Reports, the Pennatulida, 1880, p. 14.

The colony is $44 \mathrm{~cm}$. in length, of which the stalk is $5.1 \mathrm{~cm}$. The stem has a distinct enlargement just below the rachis and diminishes gradually in size to the end bulb, the two being almost of the same size and insensibly blending into each other. The diameter of the swelling is $8 \mathrm{~mm}$. and of the end bulb $5.5 \mathrm{~mm}$. The narrowest part of the stem is between the two and is $4.5 \mathrm{~mm}$. broad. The swelling has a series of very evident wrinkles or longitudinal furrows.

The polyp bodies are tubular, transversely wrinkled or corrugated, $6 \mathrm{~mm}$. high to the bases of the tentacles, $2 \mathrm{~mm}$. in diameter at the middle, diminishing slightly in diameter at each end. The tentacles are $5 \mathrm{~mm}$. long, not longer than body in specimens studied. The pinnules are numerous. The polyps are very irregularly distributed, perhaps an average distance between them is $5 \mathrm{~mm}$. They can hardly be said to be arranged in transverse rows, the midline, ventrally, being occasionally invaded by polyps, though in general it is free. On the proximal part of the rachis the polyps are scattered singly or in pairs; on the distal portion they are more crowded and generally occur in pairs or in short oblique rows of three. At the distal end they are crowded into a dense tuft, in the larger and older specimens, and their arrangement is hard to ascertain, the lateral and ventral surfaces of the rachis being entirely covered with polyps.

The ventral midline is covered, and the mass of polyps is as dense as in $A$. thomsoni Kölliker. The bases of the polyps in a given line are often slightly coherent.

Zooids: These are small and numerous, and are scattered over pretty much the whole surface of the rachis, except the ventral region, which is not occupied by a furrow and is rarely invaded by zooids. There is a narrow dorsal band, sometimes depressed, which is usually free from zooids but is occasionally invaded. The zooids are unevenly distributed, sometimes forming patches or lines, and at others scattered haphazard. They are all small.

The spicules are absent. While there are a few calcareous particles on the end bulbs, I am not sure that they are not adventitious.

Color: The upper part of the stem, the rachis, and lower parts of the polyps are pale yellowish, with a reddish-brown tinge. The upper parts of the polyps and the tentacles are warm reddish-brown, the 
former darker, sometimes a purplish-brown. The swelling and end bulb a light reddish-brown.

Localities.-Station 4765; West Point Yunaska Island, S. $37^{\circ}$ E., 43.5 miles; 1,217 fathoms. Station 4973; Shio Misaki Light, N. $82^{\circ}$ E., 12.5 miles; 600 fathoms.

General distribution.-The type-locality is North Atlantic, south of Halifax, 1,250 fathoms, Hawaiian region, 233 fathoms (Nutting). Indian Ocean, 1,000 fathoms (Thomson and Henderson).

The specimens from station 4973 are in very poor condition and may possibly be incorrectly identified.

Family ECHINOPTILIDA Hubrecht.

Small, pennatula-like forms in which the axis cylinder is wanting.

Genus ECHINOPTILUM Hubrecht.

Being the only genus of Echinoptilidæ, it has the characters of the family.

\section{ECHINOPTILUM MACINTOSHI Hubrecht.}

Echinoptilum macintoshi HuвRecht, Proc. Zool. Soc. London, 1885, p. 512.

Colony $9.2 \mathrm{~cm}$. in length, curved in a semicircle, the end bulb more sharply curved in the same direction. The stem, below rudimentary polyps, about $3 \mathrm{~cm}$. long, decreasing gradually in diameter from $7 \mathrm{~mm}$. to $4.5 \mathrm{~mm}$. near the rather sharply pointed end. Greatest diameter, across rachis, $9 \mathrm{~mm}$. The rachis is round or obscurely quadrangular in section, with a distinct groove on the concave side. The polyps are arranged in vertical rows, about 20 to a row, and also in oblique transverse rows of 6 to 7 from mid-dorsal to mid-ventral surface. Polyps $3.5 \mathrm{~mm}$. long, on outer side, to top of spines.

Each calyx margin bears two strong spines composed of groups of spicules which sometimes project as much as $1.5 \mathrm{~mm}$. above the margin. Calyces about $2 \mathrm{~mm}$. broad at base, narrowing to the margin. The calyces are smallest near the groove and lower rachis.

Zooids: These are scattered plentifully between the calyces, being absent from the groove only.

Spicules: These are all sharply pointed needles, characteristic of the pennatulids.

There is no axis cylinder.

Color: Rather dull pink throughout, the color of the needles.

Locality.-Station 4842; Saigo Misaki (Dogo Island), S. $64^{\circ}$ W., 6.1 miles; 82 fathoms.

General distribution.-The type was from the Japanese Sea, 71 fathoms. The species has also been reported from the Hawaiian Region (Nutting). 


\section{Family PROTOPTILID压 Kölliker.}

The rachis is long and slender; polyps sessile, in a single irregular series on each side; calyces present.

\section{Genus PROTOPTILUM Kölliker.}

Zooids on all sides of the rachis, leaving nothing but the ventral line uncovered.

PROTOPTIUUM ORIENTALE, new species.

Plate 6, figs. 1, 1 .

Colony $13.3 \mathrm{~cm}$. in length; stem to first rudimentary polyp $6.3 \mathrm{~cm}$., ending in an ovoid, bladder-like end bulb which is longitudinally striated and measures $11 \mathrm{~mm}$. by $7 \mathrm{~mm}$.

The least diameter of the stem above end bulb is $2.5 \mathrm{~mm}$.; median diameter $3.5 \mathrm{~mm}$.

There is a row of polyps along each side of the dorsal median space, about 10 polyps in each. The calyces are short, directed distally, with the inner walls very short or lacking. The outer wall is $3 \mathrm{~mm}$. high, and with 8 regular, large, vertical corrugations ending in lobular projections around the margin, covered with small needle-like spicules. The polyps are partly retracted, exposing but about $2.5 \mathrm{~cm}$. of their length. They are $2 \mathrm{~mm}$. in diameter, and their bodies are covered with an armature of very conspicuous spicules which are bar-shaped with the ends enlarged. They lie in every direction in the body walls, and average about $1 \mathrm{~mm}$. in length. The tentacles are about 3.5 $\mathrm{mm}$. long, and have their dorsal surfaces covered by triple or double rows of the same spicules placed longitudinally and very conspicuous. The pinnules are short and rather distant.

There is a row of rudimentary polyps, 17 in one specimen and but 4 in another. The spaces between the lateral calyces, margin to margin, are about $5 \mathrm{~mm}$.

Zooids: The ventral zooids are in two regular rows, one on each side of the dorsal surface, very regularly spaced. Opposite each of the calyces these rows become double. Sometimes there are one or two on the outer side of the base of each calyx, and there are often one or two opposite the inner margin. The zooids are conical or dome-shaped, with distinct apertures. They bear small needleshaped spicules in their walls.

The rachis ends distally in a blunt, rounded point projecting 3.5 $\mathrm{mm}$. above the last calyx.

The spicules have already been described. The bar-shaped forms in the polyps are sometimes almost fiddle-shaped.

Color: Rather dull grayish-brown throughout. $48702^{\circ}$-Proc.N.M.vol.43-12-4 
จOL. 4 รี.

Localities.-Station 5054; Omai Saki Light, S. 54 ${ }^{\circ}$ W., 29.5 miles; 282 fathoms (type). Station 5056; Ose Saki, N. $37^{\circ}$ E., 5 miles; 258 fathoms.

Type-specimem.-Cat. No. 30099, U. S. N. M.

One specimen has several expanded polyps with bodies $3.5 \mathrm{~mm}$. long. The spicules lie longitudinally in the body walls. Another specimen is attached to a shell by its end bulb, an anomalous condition for a pennatulid.

\section{Genus STACHYPTILUM Kölliker.}

Calyces present, free; zooids ventral.

\section{STACHYPTILUM MACLEARI Kölliker.}

Stachyptilum macleari Kölliker, Challenger Reports, the Pennatulida, 1880, p. 12.

Length of colony $5.9 \mathrm{~cm}$. Stem $3.5 \mathrm{~cm}$., slender, with hardly evident end bulb and swelling; greatest diameter $2 \mathrm{~mm}$. The calyces are in 12 rows on each side, 4 in each row. Rows oblique. A row of single rudimentary calyces extends quite a distance below the fully developed ones. The ventral calyces are the largest and the dorsal the smallest. The proximal and distal rows bear reduced numbers of calyces.

The calyces are contiguous, the larger ones being $2 \mathrm{~mm}$. high and very obliquely placed, their walls covered with needle-like spicules longitudinally arranged, and borders armed with an indefinite number of irregular points composed of groups of spicules. Each tentacle bears a narrow band of small bar-like spicules on its dorsal surface. These spicules do not resemble those figured by Kölliker.

The zooids are numerous on all parts of the rachis not occupied by calyces or a narrow ventral median groove. Each zooid is surrounded by a radiating fence of needle-like spicules projecting in points. The zooids extend in a line alongside of the line of rudimentary polyps described above.

Color: The entire colony is white, in alcohol.

Locality.-Station 5071; Ose Saki, S. 53.5 ${ }^{\circ}$ W., 2.6 miles; 57 fathoms.

Type-locality.-Southeast of Ceram, west of New Guinea, 129 fathoms.

The specimen described above agrees with the original description except in the shape of the tentacular spicules.

\section{Genus TRICHOPTILUM Kölliker.}

Protoptilidæ with alternate calyces which have their margins armed with 8 spines, dorsal zooids, and numerous spicules in polyps and tentacles. 
TRICHOPTILUM SPINOSUM, new species.

Plate 7, figs. $3,3 a$.

Colony $13.6 \mathrm{~cm}$. long. Stem $6 \mathrm{~cm}$. long, very slender, end bulb hardly evident and but $1 \mathrm{~mm}$. in diameter. The calyces are in two very irregular rows on opposite sides of rachis and of various sizes. Small (or young?) polyps are usually found growing just above and inside of the larger ones. Some of the larger calyces measure $6 \mathrm{~mm}$. to the ends of the spines, and have a marginal diameter of $2 \mathrm{~mm}$. The general shape of the calyx is a cylinder gradually expanded toward the margin. The margin is armed with 8 prominent spines, some of which project as much as $2 \mathrm{~mm}$., each point being composed of a number of needles gathered in a bundle. Other long needles form 8 longitudinal ridges on the calyx walls, resembling those of Pennatula. A number of smaller needles are found all over the calyx walls lying criss-cross, but tending to form a horizontal band just below the margin. An almost complete gradation can be found between the large calyces described and apparently rudimentary ones less than $1 \mathrm{~mm}$. high.

Spicules are numerous throughout the rachis.

Zooids: Although these are present, I am unable to make out any definite arrangement, or to discriminate surely between them and the smallest of the rudimentary polyps, without dissecting the only specimen secured.

Color: The stalk is straw-yellow, deepening to an orange on the end bulb. The polyps are pallid, with the distal portions showing a tinge of red. The spicules are all colorless.

Locality.-Station 4959; Mizimoko Shima Light, N. $23^{\circ}$ W., 28.5 miles; 405-578 fathoms.

Type-specimen.-Cat. No. 30100, U.S.N.M.

Genus HELICOPTILUM, new genus.

Colony in the form of a stiff spiral; calyces biserial, each with two very conspicuous spines or horns projecting from its outer margin.

HELICOPTILUM RIGIDUM, new species.

Plate 7, figs. 2, $2 a$; plate 18, fig. 5 .

Colony (incomplete) growing in an open spiral. Axis very strong and stiff, quadrate in section. The largest specimen is $21 \mathrm{~cm}$. in length, stem missing. The rachis is flattened dorso-ventrally, lesser diameter $2 \mathrm{~mm}$., greater diameter (not including calyces), $2.7 \mathrm{~mm}$. The calyces are in two rows, regularly alternate, their outer margins being very greatly prolonged into two conspicuous horns which often project as much as $2 \mathrm{~mm}$. beyond the rest of the margin. The length of 
calyx, including spines, $3.5 \mathrm{~mm}$; diameter at base, $1.9 \mathrm{~mm}$; diameter between tips of spines, $2.3 \mathrm{~mm}$. The inner sides of the calyces are cut away to the level of their bases, the polyp issuing ventrally between the enormous spines and facing directly upward as if issuing from the upper side of the calyx at its base. The calyx walls are filled with long orange-brown needles arranged vertically and parallel. Distance between calyx bases, $2.3 \mathrm{~mm}$. There is a swelling beneath each calyx base.

There are no spicules in the polyps. The tentacles have large pinnules.

Zooids: There are usually two zooids just above and inside of the base of each calyx on the dorsal? side, although there is often but one; and one in a similar position on the ventral? side. There are no grooves on the rachis, and the dorsal and ventral sides differ only in the fact that the calyces are slightly inclined toward what I consider, with some doubt, as the dorsal side. There is no fence of spicules around the zooids.

Spicules: These are all needle-like forms, slender, smooth and sharp, averaging about $1 \mathrm{~mm}$. long.

Color: Golden brown, the rachis lighter and the calyces darker. Polyps colorless.

Localities.- ? Station 4793; Toperkov Island, Harbor of Nikolski, Bering Island, N. $58^{\circ}$ E., 44 miles; 2,700 fathoms. Station 4975; Shio Misaki Light, N. $49^{\circ}$ E., 7 miles; $712-545$ fathoms (type). Station 4977; Shio Misaki Light, N. $65^{\circ}$ E., 7 miles; 544 fathoms.

Type-specimen.-Cat. No. 30042 , U.S.N.M.

A remarkable species, differing from all other pennatulids in habit of growth.

\section{Order GORGONACEA.}

Fixed colonial forms with an axis cylinder composed of calcareous or chitinous material.

\section{Section HOLAXONLA.}

Axis consisting of amorphous horny or calcareous material, or both, and not penetrated by longitudinal canals; except, in some cases, a central one.

\section{Family CHRYSOGORGID E Verrill.}

Conenchyma thin; polyps large, distant, uniserial, without distinct calyces, and with neither operculum nor collaret; root calcareous; axis often with a brilliant metallic lustre. 


\section{Genus LEPIDOGORGIA Verrill.}

Lepidogorgia Verrill, Amer. Journ. Sci. and Arts, ser. 5, vol. 28, 1884, p. 220.

Strophogorgia WRIGHT and StUdeR, Challenger Reports, The Alcyonaria, 1889, p. 2.

Colony unbranched, slender; polyps growing on one side only.

LEPIDOGORGIA PETERSI (Wright and Studer).

Strophogorgia petersi WRIGHT and STUDER, Challenger Reports, the Alcyonaria, 1889, p. 2.

Lepidogorgia petersi Versuuxs, Chrysogorgiidæ of the Siboga Expedition, 1902, p. 7.

Specimens fragmentary, the largest being $-45 \mathrm{~cm}$. long with both extremities lacking.

The stem is $2 \mathrm{~mm}$. in diameter; axis hard and stony, with a golden iridescence.

The polyps are uniserial, evenly spaced, about $4 \mathrm{~mm}$. apart, 5 to $6 \mathrm{~mm}$. in height and $2 \mathrm{~mm}$. in diameter. The polyp walls contain long bar-like spicules, often somewhat flattened, sometimes bent, with rounded ends, sometimes as much as $3.5 \mathrm{~mm}$. long. These are vertical in position. At the bases of the polyps are small groups of transverse spicules, often 3 or 4 to the group. The retracted tentacles are very irregularly disposed, being curled up and tucked together haphazard. Their dorsal surfaces are armed with bar-like spicules much shorter than those in the calyx walls. The tentacles are very unequal in size, the adcauline one being rudimentary, as pointed out by Versluys.

The stem is covered with a thin cœnenchyma the surface of which is filled with thin, flattened, scale-like spicules of various forms but not greatly branched, and with closely fitted edges. They are usually smaller than the spicules of the polyps.

Localities.-Station 4976; Shio Misaki Light, N. 59 E., 6.4 miles; 545-544 fathoms. Station 4977; Shio Misaki Light, N. $65^{\circ} \mathrm{E}$, 7 miles; 544 fathoms. Station 5080; Omai Saki Light, N. 23.5 E., 28 miles; 505 fathoms.

General distribution.-Type-locality, Yeddo, Japan, 345 fathoms. East Indies, 621-1,301 meters (Siboga Expedition).

A specimen from station 5080 was $45 \mathrm{~cm}$. long.

\section{Genus CHRYSOGORGIA Verrill.}

Colony branched; branches spirally arranged, giving off geniculate branchlets all from the same side of the branch; stem sympodial; tentacles never retractile. ${ }^{1}$

1 This definition is condensed from that given by Doctor Versluys in his excellent work on the Chrysogorgiidæ of the Siboga Expedition, 1902, p. 18. 


\section{CHRYSOGORGIA LATA Versluys.}

Chrysogorgia lata VersLuys, Chrysogorgiidæ of the Siboga Expedition, 1902, p. 33.

Colony incomplete, $18 \mathrm{~cm}$. high and with a spread of about $8 \mathrm{~cm}$. The root is missing. The branch origins are in a left-handed spiral, $1 / 4$; that is, the fourth will be immediately above the first, and the 4 origins will have made a single spiral around the stem. The average distance between branches is about $4 \mathrm{~mm}$., and they give origin to branchlets up to the fourth order. There are about 3 polyps to each internode of the branches and branchlets. The polyps are small, about $1 \mathrm{~mm}$. high to the base of the tentacles, and with bodies ovate or columnar according to the state of contraction and $0.4 \mathrm{~mm}$. in diameter. Their walls are armed with 8 rather indefinite vertical rows of spindles which are bar-shaped with rounded ends. These rows are extended over the basal portions of the tentacles, usually in double rows. The tentacles are long, with smaller spicules usually irregular in distribution but sometimes transversely disposed on distal portions. There are small spicules also on the dorsal surfaces of the pinnules.

The branches have a thin coating of flattened, scale-like spicules.

Color: The stem is grayish, lightening distally. The branches are yeliowish, with a golden gleam showing through from the iridescent axis. The polyps are white.

Localities.-Station 5091; Joga Shima Light, N. 15², W., 4.2 miles; 197 fathoms. ? Station 5079; Omai Saki Light, N. $29^{\circ}$ E., 24 miles; 475-505 fathoms. A mere fragment, not identified with certainty, was secured from this station.

General distribution.-The type was taken by the Siboga Expedition in Celebes Sea from a depth of 190 meters. Hawaiian Islands, 411-476 fathoms (Nutting).

\section{CHRYSOGORGIA FLEXILIS (Wright and Studer).}

Dasygorgia flexilis WRIGHT and STUDER, Challenger Reports, the Alcyonaria, 1889, p. 10.

Chrysogorgia flexilis Versuurs, Chrysogorgiidæ of the Siboga Expedition, 1902, p. 43.

Several fragments, mostly destitute of polyps, were secured. The first nodes of the branches are much longer than in the original description, although this is not true of the smaller specimens secured. Branches in a right-handed spiral, $2 / 5$, as described by Versluys from the type. Branchings to the fourth order are produced. There is usually but a single polyp to the internode, except in the distal ones, where there may be two or three. The polyps are expanded above and below, a typical one being $2 \mathrm{~mm}$. in height.

The walls show 8 vertical rows of bar-like spicules with ends rounded and often expanded. There are a few verrucæ on the 
spicules. The spicules at the polyp bases are more crowded and irregular, the whole spiculation being more crowded than in type, almost covering the body walls. Usually, however, there are evident bare streaks between the rows of spicules, the spicules of a given row often imbricating. The rows are extended over the basal parts of the tentacles; but are smaller, irregularly placed, often transverse on the distal parts, some extending lengthwise over the pinnules.

The stem spicules are more flattened and scale-like, often fitted as in mosaic.

Color: The proximal part of the stem is dark brown, lightening on distal parts of branches and twigs to a horn yellow. The polyps are white.

Locality. -Station 4975; Shio Misaki Light, N. $49^{\circ}$ E., 7 miles; $712-$ 545 fathoms.

General distribution.-The type is from the coast of Chile, 120 fathoms. Siboga Expedition, Last Indies, 822-918 meters. Hawaiian Islands, 280-323 fathoms (Nutting).

CHRYSOGORGIA AGASSIZII (Verrill).

Dasygorgia agassizii VerRILL, Bull. Mus. Comp. Zoöl., vol. 11, No. 1, 1883, p. 22.

Only a fragmentary specimen of this species was secured, but it shows the essential features as described by Verrill.

The base is a delicately branching mass of ivory-white rootlets which are purely calcareous. Branches $2 / 5$, in the right-handed spiral. The basal internodes of the branches are much shorter than in the last species, being about $6 \mathrm{~mm}$. long. Intermediate internodes about $5 \mathrm{~mm}$. long, with a single polyp usually nearer the distal than the proximal end of the internode.

The polyps are less obliquely placed than described by Verrill, although in some cases they assume the erect posture figured by that writer. A typical polyp measures $2.2 \mathrm{~mm}$. in height; body rather slender but expanding at each end, $1.2 \mathrm{~mm}$. broad across tentacle bases and $1.5 \mathrm{~mm}$. across the base of the polyp. The polyp walls are practically covered with vertical spicules that are not arranged in vertical bands of eight, although there is sometimes such a tendency in the distal parts. Double rows of thin, broad-ended spicules extend along the basal parts of the dorsal surfaces of the tentacles. Similar but smaller spicules lie transversely across the distal portions of the tentacles.

Spicules: These are bar-like with slightly expanded and rounded ends, and are distinctly tuberculate. The cœnenchyma is rather thick, white, and contains few spicules.

Color: The stem is golden yellow and the polyps and branches white. 
Locality. -Station 5080; Omai Saki Light, N. 23.5 E., 28 miles; 505 fathoms.

Type-locality.-Georges Bank, Atlantic coast of United States, 1,242 fathoms.

\section{CHRYSOGORGIA DICHOTOMA Thomson and Henderson.}

Chrysogorgia dichotoma THomson and Henderson, Alcyonaria of the Indian Ocean, I, Alcyonaria of the Deep Sea, 1906, p. 29.

The specimens are all incomplete. One is $6.8 \mathrm{~cm}$. in height, with a diameter of $6.3 \mathrm{~cm}$. The stem is very strong, wiry, and brittle. The branches are arranged in a spiral of $1 / 5$, left-handed. The branches are closely approximated, a whorl occupying but $3 \mathrm{~mm}$. of the stem. The longest branch is $4.2 \mathrm{~cm}$. in length. The branches divide dichotomously, sometimes forking as much as five times. The polyps are lacking on the main stem, and on the proximal internodes of the branches. On one branch there are 3 polyps on the third internode, 7 on the fourth, 6 on the fifth, and 2 or 3 on the last. The fourth internode is the longest $(12 \mathrm{~mm}$.). Many of the polyps are stripped off, but it is not uncommon to find as many as 8 on an internode.

The individual polyps have the bodies greatly expanded with ova, thus being ovate in shape and enlarging again at tentacle bases; small, measuring less than $1 \mathrm{~mm}$. to tentacle bases. The body spicules are bar-shaped, not scales, with somewhat enlarged ends, more slender than in C. japonica. ${ }^{1}$ They are irregular in distribution, with a decided tendency to a vertical position, sometimes with an approach to 8 longitudinal bands. The dorsal surfaces of the tentacles are covered with sharply marked bands of similar spindles, there being two to three rows to the band. Similar but somewhat more slender spicules are embedded loosely in the cœnenchyma of the twigs and branches.

The zooids are numerous on the surfaces of the branches between the polyps.

Color: The axis is dark green, with a metallic luster in main stem. The branches are golden-brown proximally, lightening distally to a light green. The axis of the branches and twigs has a brilliant green luster except at ends of twigs. The polyps, in alcohol, are of a decided reddish-brown, thus differing from any others that $I$ have seen in the genus.

Localities.-Station 4894; Ose Saki Light, N. $41^{\circ}$ E., 5 miles; 95 fathoms. Station 4936; Sata Misaki Light, N. 21 E., 5.7 miles; 103 fathoms.

The type-locality is in the Indian Ocean. 
The number of polyps to the internode and the color of the polyps are distinguishing marks of this species.

\section{FAMILY PRIMNOID正.}

Colonial Gorgonacea with calcareous roots. Axis calcareous or horny, but never with alternating calcareous and horny joints. Calyces with opercula composed of 8 scales. Polyps often in whorls, their walls covered with scale-like spicules.

\section{Subfamily CALYPTROPHORIN AE Versluys.}

Calyx spicules reduced to two or three pairs of large scales. ${ }^{1}$ Operculum conspicuous, turned toward branch when the polyp is retracted.

\section{Genus CALYPTROPHORA Wright and Studer (emended by Versluys).}

Calyx body with but two pairs of very large scale-like spicules usually entirely encircling the polyp.

\section{CALYPTROPHORA IJIMAI Kinoshita.}

$$
\text { Plate 16, figs. 2, } 3 .
$$

Calyptrophora ijimai Krnoshrta, Ann. Zool. Japan, ser. 6, vol. 3, 1907, p. 234. Arthogorgia membranacea KÜKentHaL and GoRZAWSKY, Japanische Gorgoniden, Teil I, 1908, p. 29.

Colony $10.5 \mathrm{~cm}$. in height. The first branch arises $8 \mathrm{~mm}$. above the base. The branches are pinnately arranged, alternate, undivided and erect, originating at an acute angle with the main stem and sometimes attaining a length of $7 \mathrm{~cm}$. Diameter of the main stem $1.3 \mathrm{~mm}$. The branches are attenuated and straight, ending in a mere thread.

The axis has a light green iridescence near its base, where it is apparently striated. There is no luster in the axis of stem and branches.

The polyps are in whorls of 4 or 5 , all facing downward. The whorls are about $2 \mathrm{~mm}$. apart. Calyces $2.2 \mathrm{~mm}$. in height (measured parallel with the branch) and project about the same distance from the branch. Both the basal and distal pairs of spicules form incomplete rings, failing to meet on the stem side, and in both the individual spicules of a pair are cemented together. The distal pair bears four sharply pointed spines projecting nearly $1 \mathrm{~mm}$. from the free fluted border. This pair is about $1.6 \mathrm{~mm}$. long to base of spines.

The basal pair bears two very slender, often curved, spines projecting nearly $2 \mathrm{~mm}$. beyond the border. This pair is almost $2 \mathrm{~mm}$. 
long. The base of the polyp is surrounded by a group of much smaller scales, forming a sort of collar in which the polyp is encircled.

The operculum is strongly developed, as is usual in this genus; but it is rather high, and the individual scales are slender triangles with their distal ends sharply pointed. Those on the abaxial side are longer than the others and overlap them considerably.

The branches are covered with a complete layer of comparatively small, flattened, irregular scales.

Color: The basal part of the stem and branches very pale yellow, calyces white.

Localities.-Station 5079; Omai Saki Light, N. $29^{\circ}$ E., 24 miles; 475-505 fathoms. Station 5080; Omai Saki Light, N. $23.5^{\circ}$ E., 28 miles; 505 fathoms. Station 5087; Joka Sima Light, S. 84.5 E., 14.8 miles; 614 fathoms.

General distribution.-Type-locality, Sagami Sea, 550 fathoms. Okinose Bank, 400 fathoms. Yodomi, Sagami Bay.

Superficially the calyces of this species greatly resemble those of C. japonica; but they all face downward, and both pairs of scales form an incomplete ring.

The specimens secured by the U.S. Fisheries steamer Albatross all show the curious membranaceous structure formed of strangely modified spicules which give refuge to a symbiotic annelid.

\section{CALYPTROPHORA JAPONICA Gray.}

Calyptrophora japonica Grar, Proc. Zool. Soc. London, 1866, p. 25.

Colony incomplete, $13.1 \mathrm{~cm}$. in height. The branchlets arise from tho upper sides only of the branches, regularly spaced, $6 \mathrm{~mm}$. apart and about $11 \mathrm{~cm}$. long. The calyces are in whorls of 4 to 6 on the distal parts of branches and are about $2 \mathrm{~mm}$. long. Both proximal and distal pairs of calyx spicules form a closed ring. The distal ring has four spines projecting downward, and the proximal ring has two spines projecting outward.

The polyps face the base of the stem or branch.

Operculum not very prominent, dome-shaped. Each fiap is thin, triangular, with edges turned upward, the adaxial plate being much smaller than the others.

The branches are covered with flattened scales of irregular shape.

Color: The axis is almost black proximally, lightening distally. The colony in general is light brown.

Localities.-Station 4924; Nagada Saki, N. $8^{\circ}$ E., 18 miles; 159 fathoms. Station 4935; Sata Misaki Light, N. $58^{\circ}$ E., 4.5 miles; 103 fathoms.

General distribution.-The type was from Japan. The Challenger found it near the Fiji Islands, 610 fathoms. The Siboga expedition secured it from the Malay Archipelago, 400-1,301 meters. Hawaiian 
Islands, 135-577 fathoms (Nutting). Japan, Satsuma, and Sagami Sea, 300-400 fathoms (Kinoshita).

The U.S. Fisheries steamer Albatross specimens closely resemble the one figured by Kinoshita.

\section{CALYPTROPHORA KERBERTI Versluys.}

Calyptrophora kerberti Versuuys, Primnoidæ of the Siboga Expedition, 1906, p. 105.

Several fragments of this species were secured from station 5093. The largest specimen is $9.5 \mathrm{~cm}$. high, dichotomously branched. The polyps face downward, many of them broken off in the specimen, normally in whorls of four. Whorls about $2 \mathrm{~mm}$. apart. The calyces are about $2 \mathrm{~mm}$. high, and project $1.7 \mathrm{~mm}$. from the branch. The basal scales do not form a complete ring on inner side, each with a spine-like process from its distal end and outer corner a little more than $1 \mathrm{~mm}$. long. Buccal scales also forming an incomplete ring, often with no spines on distal ends, as figured by Versluys, but quite frequently showing two small spines. There is often a small ridge or keel at the superior junction of these two scales. The margin is not so straight as represented by Versluys, but is more or less sinuous and hood-shaped.

The scales in the branches are thin, often slender, and their ends are imbricating.

The axis is almost black proximally, lighter distally: The branches are gray and the calyces are almost white.

Locality.-Station 5093; Joga Shima Light, N. $8^{\circ}$ W., 5 miles; 302 fathoms.

The type-locality is Japan (Hilgendorf).

Genus STACHYODES Wright and Studer.

Calyx consisting of three pairs of large scale-like spicules, the basal pair usually not completely encircling the polyp.

STACHYODES MEGALEPIS Kinoshita.

Stachyodes megalepis Kinosmita, Primnoidæ von Japan, 1908, p. 47.

Several small specimens secured by the U. S. Fisheries steamer Albatross agree quite closely with the original descriptions and figures of this species.

Colony incomplete, $12.3 \mathrm{~cm}$. high, flabellate in form. The main stem, or branch, gives off two main branches which divide dichotomously into four. The axis has a greenish-gold luster. On the basal parts the calyces are in whorls of 7 or 8 ; on the distal parts they are in whorls of 5, closely approximated. Calyces about $3 \mathrm{~mm}$. high. The basal scales are the largest and the middle pair the smallest, each pair with its margin curved slightly backward, and each has the appearance of having a marginal border of different texture from the 
rest of the scale. The pairs all fail to make a complete ring, being lacking on the adaxial side.

The operculum is composed of very thin scales more or less fluted or frilled on the edges, so that the borders are turned upward. The adaxial scales are much smaller and have much less pronounced frills than the others.

The branches are covered with small thin fluted scales. In places these are enormously enlarged by a parasitic annelid, forming an arcade along the branch, which furnished a character for Allman's genus Calypterinus. ${ }^{1}$

Color: The colony is dull, yellowish-brown.

Localities.-Station 4918; Gwaja Shima, S. $38^{\circ}$ E., 34 miles; 361 fathoms. Station 4935; Sata Misaki Light, N. 58 ${ }^{\circ}$ E., 4.5 miles; 103 fathoms. Station 4936; Sata Misaki Light, N. 21 E., 5.7 miles; 103 fathoms.

General distribution.-The type was secured from Gokeba, southwest from the Province of Awa, Japan. Another fragment was from the Sagami Sea.

\section{Genus CALIGORGIA Gray (emended by Versluys).}

Colony flabellate, pinnate or dichotomous, without secondary branchings. Calyces in whorls, club-shaped, appressed to the branches and with their adaxial walls incomplete. Circumopercular scales lacking.

\section{CALIGORGIA FLABELLUM (Kölliker).}

Primnoa flabellum KöllikeR, Icones Histologicæ, vol. 2, 1865, p. 135.

Calligorgia flabellum Studer, Monatsber. Akad. Wiss. Berlin, 1878, p. 646.

Colony $20 \mathrm{~cm}$. high, strictly flabellate, breaking up near its base into four large branches which are scarcely flattened. Secondary branches rare. Branchlets regularly alternate, averaging about 6 $\mathrm{mm}$. apart, all in one plane.

The calyces are clavate, much curved, nearly facing the branch. Ordinarily they are in whorls of four, but increase proximally until there are as many as 18 on the bases of the larger branches. The individual calyces are $1.5 \mathrm{~mm}$. in height, and nearly uniform in diameter. There are usually about 8 whorls to the $\mathrm{cm}$. There are 7 scales in each of the abaxial rows and 4 or 5 in the outer lateral rows. Adaxial scales 2. The sculpturing on the distal scales is not so pronounced as figured by Versluys and Kinoshita; but the calyces are practically identical with those figured by Wright and Studer.

The operculum is high, conical, composed of slender triangular flaps, the adaxial ones being shorter than the others. All of the spicules are plainly granulated. 
Color: The colony is a light buffy-brown.

Lacality.--Station 4936; Sata Misaki Light, N. $21^{\circ}$ E., 5.7 miles; 103 fathoms.

General distribution.-Pacific and Indian Oceans; Japan. Down to 1,250 meters.

\section{CALIGORGIA VENTILABRUM Studer.}

Caligorgia ventilabrum Studer, Monatsber. Akad. Wiss. Berlin, 1878, p. 647.

A number of very large fragments of one or more specimens of this species were collected by the U. S. Fisheries steamer Albatross. Station label lost.

One fragment is $54 \mathrm{~cm}$. long. Diameter at base $6.5 \mathrm{~mm}$. The main branch is somewhat flattened. The branching is typically dichotomous, except that the main branch gives off a number of laterals, mainly from one side. The terminal twigs are very long, as much as $20 \mathrm{~cm}$. in some cases. All of the branches are erect, nearly parallel, the whole forming a flabellate structure. The average diameter of the secondary branches is $4 \mathrm{~mm}$.

The calyces are in regular whorls of 4 on distal ends of branchlets and 12 on large branches. On the longest branches they are irregular, often wanting. There are but 4 or 5 whorls of calyces to the $\mathrm{cm}$. The individual calyces are large, $2 \mathrm{~mm}$. long, with 9 or 10 scales to the adaxial and outer lateral rows. Some of the latter have the peculiar lateral processes figured by Versluys in Caligorgia affinis. ${ }^{1}$ Otherwise the specimens agree better with $C$. ventilabrum.

The inner laterals and adaxials are greatly reduced in number, being apparently represented by their distal elements alone; although these appear to be rudimentary scales representing the basal ones.

The operculum is not conspicuous, composed of smooth triangular scales, the adaxial being the smallest and the abaxial the largest and overlapping slightly the others.

Color: The axis is almost black proximally, lightening distally. The general color of the colony is very light tan-brown.

Locatity.-Label lost.

Type-locality.-North of New Zealand, 90 fathoms.

A very fine species. The specimens just described are the largest of the genus.

\section{CALIGORGIA ASPERA Kinoshita.}

Caligorgia aspera Krnoshuta, Primnoidæ von Japan, 1908, p. 39.

Colony in fragments, the longest piece being $12.2 \mathrm{~cm}$. long and with a spread of $6.2 \mathrm{~cm}$. There are branches on two sides of the main branch, forming a flabellate structure; side branches dividing dichotomously sometimes to branchings of the sixth order and attaining a length of $5.9 \mathrm{~cm}$. in some cases. 
The calyces are ordinarily in whorls of 3 , the 3 being on front and sides of the branch, usually leaving the back free from polyps. There are 8 to 10 whorls to the $\mathrm{cm}$. On thicker parts of branches whorls of 4 , rarely 5, are seen. They are seldom in pairs, except at the very ends of the twigs. The individual calyces are strongly curved, their distal ends turned toward the branch. They are $1.5 \mathrm{~mm}$. long, measuring with dividers across the curve, and about $1 \mathrm{~mm}$. in opercular diameter. The scales are well marked, apparently imbricating and with their surfaces covered with pointed granules. The calyx margin is quite even, being squarely cut off all around, although the abaxial scales may form slight rounded lobes. The abaxial rows contain usually 6 , sometimes 5 , scales; outer lateral with one large distal scale and sometimes another proximal one. Occasionally one or two small inner laterals can be seen, but they are not constant.

There are no adaxials.

The operculum is strong, dome-shaped, with scales thick, heavily granulated, with large basal lateral lobes and narrowing distally to a comparatively slender point. The basal edges of the abaxials overlap the outer laterals, and these overlap the inner laterals. The adaxial opercular scales are shorter than the others, but are not overlapped by their points.

The scales on the twig surfaces are rounded, flat, rather large and granulated like those of the calyces.

Color: The axis is light green with a golden luster. The general color of the calyces and branches is tan-brown.

Localities.-Station 4936; Sata Misaki Light, N. $21^{\circ}$ E., 5.7 miles; 103 fathoms. ? Station 5070; Ose Saki, S. $8^{\circ}$ W., 1.8 miles; 108 fathoms.

General distribution.-Type-locality, west coast of Satsuma, Japan. Subfamily THOUARELIIN AE Versluys.

Colony usually pinnate and with secondary short branches. Calyces arranged in various ways, seldom appressed to the branch. Longitudinal rows of calyx scales evident, not greatly reduced on the adaxial side.

Genus PLUMARELLA Gray (modified by Kinoshita).

Colony pinnate, with short twigs, but never with secondary short twigs. Calyces never in well-defined whorls or in pairs, with openings directed distally. Polyp scales in 8 longitudinal rows, without circumopercular scales. Operculum evident. 
PLUMARELLA SPINOSA Kinoshita (not Kitkenthal).

Plumarella spinosa Kinoshita, Primnoidæ von Japan, 1908, p. 11.

Colony $35 \mathrm{~cm}$. long, and with a spread of $25 \mathrm{~cm}$.; strictly flabellate, the main stem giving off irregularly alternate main branches which themselves give off a few irregularly disposed secondary branches. Ultimate branches irregularly alternate, forming a plane surface, about 10 or 12 to $5 \mathrm{~cm}$. The calyces are in 2 rows on distal ends of twigs only, otherwise in 3 to 5 irregular rows, but not in whorls; clubshaped, $1.5 \mathrm{~cm}$. high including operculum, and $1 \mathrm{~mm}$. broad at distal end. The margin is armed with usually 4 , sometimes 5 or 6 , not very long points. The scales are in 8 rows, 6 to the row except in the adaxials, which have 3 . The scales regularly imbricating, each with a rounded distal edge.

The operculum is only moderately elevated, composed of flat triangular flaps, the ends of the adaxial ones being tucked under the ends of the others.

Color: Axis dark brown, lightening distally. General color light buffy-brown.

Localities.-Station 4769 ; lat. $54^{\circ} 30^{\prime} 40^{\prime \prime}$ N.; long. $179^{\circ} 14^{\prime} \mathrm{E}$.; 244-237 fathoms. Station 4781 ; lat. $52^{\circ} 14^{\prime} 30^{\prime \prime}$ N.; long. $174^{\circ} 13^{\prime}$ E. ; 482 fathoms. Station 4787 ; north point Copper Island, N. $79^{\circ}$ E., 8.5 miles; $54-57$ fathoms.

Distribution.-The type was from Mochiyama, Japan, 180 fathoms, and other specimens from Doketsuba, Japan, 130 fathoms.

The calyces resemble the type quite exactly. The specimen described above is coarser than the type and usually has 4 rows of calyces instead of 2 , although there are 2 on the distal ends of the twigs.

PLUMARELLA FLABELLATA Versluys.

Plumarella flabellata Versuurs, Primnoidæ of the Siboga Expedition, 1906, p. 16.

A fragmentary specimen is referred to this species. It consists of a single branch $18 \mathrm{~cm}$. long, slightly flattened (the cross section is $2 \mathrm{~mm}$. by $2.5 \mathrm{~mm}$.), forking distally.

The ultimate branches are alternate, 10 or 11 to $5 \mathrm{~cm}$. in length of branch. The calyces are irregularly distributed on all sides of the branches, sometimes in pairs but never in regular whorls, thickly crowded, 25 to 30 in $1 \mathrm{~cm}$. They are small, stout, club-shaped, usually less than $1 \mathrm{~mm}$. in height. The scales are heavy, coarsely granulated, the edges with irregular lobes and points or irregularly ctenate. Some of the marginal scales bear short spines, but they are often as represented by Versluys. Some of these points are triangular and others are spatulate. The adaxials are 3 or 4 in number; the abaxials 6. 
The operculum is strongly developed, conical, each flap consisting of a triangular scale beset with sharp points, the inner scales not much smaller than the outer.

Locality.-Station 4784; East Cape, Attu Island, S. $18^{\circ}$ W., 4 miles; 135 fathoms.

General distribution.-The type-locality is Japan.

The specimen differs from the type in the superficial granulation of the scales and the presence of spines on many of the marginal scales, but it agrees well in other details.

\section{PLUMARELLA CARINATA Kinoshita.}

Plumarella carinata KınoshrTA, Primnoidæ von Japan, 1908, p. 17.

Several specimens, mostly fragmentary, evidently belong to this very well-marked species.

The calyx scales differ from others of the genus, except $P$. costata Kükenthal, by having well marked median carinæ. These keels, however, are not easily seen when the specimen is immersed in fluid; but become quite evident when the specimen is partly dried.

Another characteristic pointed out by Kinoshita is the comparatively small size of the abaxial scales, these being actually smaller than the laterals, a character that is very rare in this family. Another peculiar feature is the abrupt turning upward of the calyx, which has its basal part projecting outward and its distal part turned upward, thus resembling a tobacco pipe in form. This results in the adcauline side of the calyces being entirely free from the branches.

Localities.-Station 4893; Ose Saki Light, N. $29^{\circ}$ E., 5.5 miles; 10695 fathoms. Station 4894; Ose Saki Light, N. $41^{\circ}$ E., 5 miles; 95 fathoms. Station 4895; Ose Saki Light, N. $42^{\circ}$ E., 4.7 miles; 95 fathoms.

General distribution.-The type-locality is Kozu Island, south of the Province of Izu, Japan.

This species very closely resembles Plumarella cristata Kükenthal,1 with which it may be identical, although this is denied by Kinoshita.

PLUMARELLA SPICATA, new species.

Plate 8, figs. 2, $2 a$; plate 18, fig. 6 .

A number of fragments from Station 4780 resemble Plumarella longispina Kinoshita, ${ }^{2}$ but seem to be fairly distinct.

Colony very loose and straggling in habit, flabellate, irregularly branching. The terminal twigs are about 6 to 8 in $5 \mathrm{~cm}$. in length of branch. The calyces are irregularly distributed on two sides of the branch, and are only accidentally in pairs. They often project at a 
right angle from the branch, but are usually inclined outward and upward. Calyces about $1 \mathrm{~mm}$. high to base of spines, club-shaped, but not so much bent as is usual in this genus, although there is considerable variation in this feature.

The marginal scales have long sharp spines, sometimes $1 \mathrm{~mm}$. in length. There are 6 scales to each abaxial and outer lateral rows, and 5 scales to each inner lateral and adaxial row. All the scales have minutely ctenate edges and minutely granulated surfaces.

The operculum is very high, reaching almost to the ends of the spines, each scale being an acute-angled triangle, and the adaxial ones being scarcely shorter than the others.

The spicules of the stem and branches form an irregular mosaic, and do not greatly overlap.

Color: The axis has a bright golden metallic luster, except on the proximal parts of the large branches, where it is greenish-brown. The general color of the colony is very light buffy-brown.

Locality.-Station 4780 ; lat. $52^{\circ} 01^{\prime}$ N.; long. $174^{\circ} 39^{\prime}$ E.; 1,046 fathoms (type). ? Station 4771 ; lat. $54^{\circ} 30^{\prime} \mathrm{N}$.; long. $179^{\circ} 17^{\prime} \mathrm{E}$.; 426 fathoms. Specimens from the latter station are so fragmentary and broken up that they are identified with doubt.

Type-specimen.-Cat. No. 30050, U.S.N.M

This species has a more loose and straggling habit than any other of the genus that I have seen.

PLUMARELLA ADHAERANS, new species.

Plate 8, figs. 1, $1 a$; plate 19, fig. 1 .

Colony (incomplete) $19 \mathrm{~cm}$. long. The main stem, or branch, is flattened, being 2 by $3 \mathrm{~mm}$. in section, and is forked near its middle. There are few secondary branches.

The terminal twigs are in the same plane, alternate, and are usually 6 or 7 to each $2 \mathrm{~cm}$. of length of stem or branch. The calyces are in two rows, but not in pairs, usually alternate, and there are usually 11 or 12 to each $\mathrm{cm}$. of branch.

The individual calyces are short, stout, almost conical, with the adaxial sides closely appressed to the branch almost to the margin, a little over $1 \mathrm{~mm}$. in height and $0.7 \mathrm{~mm}$. broad at margin. Abaxial and outer lateral marginal scales armed with sharp spines; otherwise the margin is quite even and clean cut all around. Abaxial and lateral scales 5 in a row; adaxial rows with 2 wide short scales. All of the scales have even margins, not ctenate, but often with a central lobe and comparatively smooth surfaces.

The operculum is a low cone or dome, well developed, each flap being a rather broad flat triangle, the adaxial ones being but slightly smaller than the others and with their points scarcely overlapped by $48702^{\circ}$-Proc.N.M.vol.43-12-5 
the latter. The scales on the branches are rather large plates, the twigs themselves being thicker than usual. The scales often have their edges imbricating.

Color: The axis is a dull yellowish-olive, branches and calyces light buffy-brown.

Localities.-Station 4894; Ose Saki Light, N. $41^{\circ}$ E., 5 miles; 95 fathoms. Station 4895; Ose Saki Light, N. $42^{\circ}$ E., 4.7 miles; 95 fathoms. Station 5070; Ose Saki, S. $8^{\circ}$ W., 1.8 miles; 108 fathoms (type).

Type-specimen.-Cat. No. 29799, U.S.N.M.

This species is distinguished from others of the genus by the size and form of the calyces.

Genus THOUARELLA Gray (modified).

Colony usually flabellate and pinnate; ultimate twigs springing from all sides of the branches, very numerous; calyces either isolated or in whorls, club-shaped, seldom adherent to the branches; calycular scales in 8 rows, at least distally. ${ }^{1}$

\section{THOUARELIA HILGENDORFI (Studer).}

Plumarella hilgendorfi Studer, Monatsber. Akad. Wiss. Berlin, 1878, p. 648.

Colony (incomplete) $14 \mathrm{~cm}$. high and with a spread of $4.6 \mathrm{~cm}$. A single branch only is present in the specimen described, which gives off numerous twigs from all sides so closely set that a spiral arrangement can not be made out, and attains a length of $3.9 \mathrm{~cm}$. Those from the front of the colony are shorter, giving the whole specimen a flabellate appearance. The calyces are in whorls or short spirals of 3 , the summit of one not usually reaching the base of the one next above. There are about 18 whorls to $2 \mathrm{~cm}$. in length of branches.

The individual calyces are rather slender cones, but slightly bent toward the axis. Some are almost straight symmetrical cones, 1.3 $\mathrm{mm}$. high to margin. Each circumopercular scale has a median keel that is produced into a prominent point which is more pronounced than in Versluys's description. The eight rows of scales overlap laterally, so as to be obscured on proximal portions. There are apparently 6 scales in the abaxial rows and 5 adaxials. The operculum is concealed by the circumopercular scales. It is composed of triangular flaps, the adaxial somewhat smaller than the others, and with their ends overlapped by the ends of the others.

The stem scales are thin and more or less imbricating.

Color: The colony is light yellowish-brown.

Localities.-Station ? 4771 ; lat. $54^{\circ} 30^{\prime}$ N.; long. $179^{\circ} 17^{\prime}$ E.; 426 fathoms (fragment). Station 4895; Ose Saki Light, N. $42^{\circ}$ E., 4.7

I Some of the points in this definition are condensed from that given by Kinoshita, Primnoidæ von Japan, 1908 ,p. 21. 
miles; 95 fathoms. Station 4934; Sata Misaki Light, N. 77.5 E., 7 miles; 152-103 fathoms (large colony, more decidedly brown than the others). Station 4936; Sata Misaki Light, N. $21^{\circ}$ E., 5.7 miles; 103 fathoms. Station 5070; Ose Saki, S. $8^{\circ}$ W., 1.8 miles; 108 fathoms (much like the next, but the polyps are smaller; spiculation the same). Station 5093; Joga Shima Light, N. $8^{\circ}$ W., 5 miles; 302 fathoms (brighter in color; spines very slender).

General distribution.-The type was from Yeddo Bay, Japan. Other localities are Kei Islands, East Indies, 204-540 meters; Sagami Bay, Japan, 100-400 fathoms; Suruga Bay, Japan, 1,200 fathoms; Indian Ocean, 371 meters.

These specimens differ from Versluys's figures ${ }^{1}$ in slenderness of calyces and prominence of spines. The latter is also noted by Kinoshita in his description of this species.

This is a very abundant and variable species, but the intergradations indicate that all of the specimens noted belong to the same form.

THOUARELLA RECTA, new species.

Plate 7, figs. 1, 1a; plate 19, fig. 2.

Colony incomplete, consisting of a stem $4.7 \mathrm{~cm}$. long, on the distal part of which the branches are arranged in spirals of three, while they are arranged irregularly on the proximal portion. The branches are usually simple, often fork, and occasionally give off branchlets. The longest ultimate branchlet is $2.4 \mathrm{~cm}$. long. Twigs very slender, those of a given row being about $2 \mathrm{~mm}$. apart. Polyps quite distant, very irregularly distributed, mostly lateral, but showing a tendency to an arrangement in long spirals of about 5 to a turn, each spiral occupying about $4 \mathrm{~mm}$. of the length of the twig.

The calyces stand straight out from the branch, as in Stenella, and are almost radially symmetrical, although the mouth is often slightly inclined toward the distal end of the colony. The height of a typical calyx is about $1.4 \mathrm{~mm}$., although they vary greatly in size, as if calyces in various stages of growth were irregularly distributed along the branches. The circumopercular scales are all armed with long slender spines. There are six scales to each longitudinal row in the calyx walls, all provided with finely ctenate edges.

The operculum is rather low and nearly concealed by the circumopercular spines. The opercular scales are triangular, and there is little if any distinction between the adaxial and the others. The large edge of these scales is ctenate.

The scales of the stem and branch surfaces are rounded or irregular, with some imbrication of their edges, and form two layers. 
Color: The axis is a golden brown on the proximal parts of the fragment, lightening distally. The calyces and cœnenchyma of the branches are very light, almost white.

Locality.-Station 5079; Omai Saki Light, N. 29 E.; 24 miles; 475-505 fathoms.

Type-specimen.-Cat. No. 30040, U. S. N. M.

This species resembles Thouarella laxa Versluys, ${ }^{1}$ but it differs consistently in the arrangement of the calyces, which are never, or only accidentally, in pairs, as in the latter species.

THOUARELLA TYPICA Kinoshita.

Thouarella typica Kinoshita, Ann. Zool. Japan, ser. 6, vol. 3, 1907, p. 23.

The specimen secured by the U. S. Fisheries steamer Albatross is broken, but two specimens that seem to match measured together $32 \mathrm{~cm}$., with a spread of $5.6 \mathrm{~cm}$. The stem is superficially very dark, almost black. Greatest diameter $4.3 \mathrm{~mm}$. The stem gives off two branches. The twigs are very densely aggregated, forming a thick flattened brush, and arise from all sides of the stem, the longest being about $3.2 \mathrm{~cm}$. in length.

The calyces are in very short verticils of 2 or 3, there being 10 to 12 verticils to $1 \mathrm{~cm}$. in length of twig. The individual calyces are rather slender clubs, often almost conical, standing with their inner sides almost touching the branch and their mouths opening upward. They are little over $1 \mathrm{~mm}$. in height with an opercular diameter of about $0.7 \mathrm{~mm}$. Calyx scales in very irregular rows, with plain rounded distal edges. The abaxial and lateral rows have 6 scales to the row, and the adaxials 4 . The circumopercular scales have each a strong keel projecting from the inner side of its distal edge, and this keel ends in a rather blunt flattened point.

The operculum is quite low and is concealed by the circumopercular scales. Flaps rather slender triangles, those of the adaxial side being shorter than the others and having their edges tucked under them.

The scales of the cœnenchyma are rounded and often imbricated like fish scales.

Color: The axis is very dark, almost black, in the stem and twigs almost to their distal ends. The general color of the colony is a grayish-brown.

Localities.-Station 4894; Ose Saki Light, N. $41^{\circ}$ E., 5 miles; 95 fathoms. Station 4936; Sata Misaki Light, N. 21 E., 5.7 miles; 103 fathoms.

The type-locality is west coast of Satsuma, Japan. 
THOUARELLA STRIATA Kükenthal.

Plate 10, figs. 2, $2 a$.

Thouarella striata KüKentral, Gorgoniden des Deutschen Tiefsee Expedition, 1907, p. 204.

Colony flabellate in form, $32 \mathrm{~cm}$. in height and with a spread of $25 \mathrm{~cm}$. The main stem is $1 \mathrm{~cm}$. thick near base, and flattened, as are the main branches, and after sending off a few irregular small branches on one side the stem $(11.5 \mathrm{~cm}$. from its base) divides into two large branches. These divide irregularly into several branchlets, and these again sometimes divide until branchings of the fifth order are reached. The ultimate twigs are pinnately arranged, close set, often forking, and forming a flabellate structure.

The calyces are in irregular whorls of 5 or 6 to even 10, closely set, nowhere distinct; but the calyces are arranged as in the genus Eunicea, for instance, without distinction of well-defined whorls even on the ultimate twigs. The calyces distinctly overlap. In 1 $\mathrm{cm}$. there are about 10 calyces in as near a longitudinal series as can be found. The individual calyces are not so decidedly bent toward the branch as is usual in this genus, but the adaxial rows of scales are reduced to 2 or 3 . The calyces are about $1.5 \mathrm{~mm}$. high, club-shaped, with a greatest diameter of about $1 \mathrm{~mm}$. The polyps face upward, not inward. The scales all have ctenate edges, the upper ones have radiating ribs and the basal ones are without evident ribs. All scales have distinctly granulated or verrucose surfaces, and the distal ones have radiating ridges, as stated above.

All but the adaxial scales have usually 6 scales each, and the distal scales have each a median rather blunt projecting point and a series of smaller lateral points on either side.

The operculum is low, scarcely projecting above the marginal points, the individual flaps being rather thick triangular scales with a roughly granulated surface. The abaxial ones project over the points of the adaxial.

The cœnenchyma of the branches is covered with a mosaic of irregular scales.

Locaiity.-Station 4778, Semisopochnoi Island, right tangent S. $45^{\circ} \mathrm{W}$., left tangent S. $12^{\circ} \mathrm{W}$., about 12 miles; 43-33 fathoms.

Type-locality.--East side of Bouvet Island, South Sea, 457 meters.

The lateral branches and terminal twigs of the specimen described are coarser than is usual in this genus, reminding one of Caligorgia.

THOUARELLA ALTERNATA, new species.

Plate 9, figs. 1, $1 a$; plate 19, fig. 3.

Colony $16 \mathrm{~cm}$. high, and with a sprear of $5.6 \mathrm{~cm}$. The ultimate branches are borne on three sides of the main stem and reach a length of $3.2 \mathrm{~cm}$, and are thickly emplanted, the distance between adjacent 
voL. 43 .

ones in a given row being but $3 \mathrm{~mm}$. The calyces are distant and usually regularly alternate, averaging about $2 \mathrm{~mm}$. apart. They are considerably curved, with large distal and slender proximal parts, as if borne on pedicels, they are almost never in pairs and are usually regularly alternate with the mouths opening upward. A typical calyx is $1.5 \mathrm{~mm}$. high to margin. The scales are all thin and delicate, the circumopercular ones with long sharp spines, those on the adcauline scales being very short or absent. The edges of the calyx scales are minutely ctenate. The circumopercular spines are $1 \mathrm{~mm}$. long and very slender. Owing to the delicacy of the scales it is hard to determine the number in the several rows, but they are more numerous than usual, probably 8 or 9 in the abaxial rows and 6 or 7 in the laterals, and apparently 4 in the adaxials.

The operculum is low, conical, composed of such exceedingly delicate scales that they are seen with difficulty by reflected light. They are flat, triangular. The tentacles of the polyps are partly protruded.

The scales are the most delicate of any that I have seen in this family, but are of the common type found in Thouarella, Caligorgia, etc.

Color: The axis of the stem is golden-green. The general color of the colony is almost white.

Localities.-Station 5079; Omai Saki Light, N. $29^{\circ}$ E., 24 miles; 475-505 fathoms. Station 5080; Omai Saki Light, N. $23.5^{\circ}$ E., 28 miles; 505 fathoms (type).

Type-specimen.-Cat. No. 30097, U.S.N.M.

The alternate disposition of the calyces and the number and extreme delicacy of the body scales are characteristic features of this species.

\section{Genus PRIMNODENDRON, new genus.}

Colony growing in dense flabellate tufts, each branch giving off a series of branchlets from all sides and each branchlet dividing into a dense tuft of terminal twigs which together form a closely compacted mass of twig terminations, most of which are directed anteriorly, forming a peculiar matted surface. Calyces in indistinct rows, being neither in pairs nor in whorls. Individual calyces much like those of Plumarella.

Primnodendron differs from Plumarella in bearing secondary branchings from the terminal twigs, and from Thouarella in having the calyces arranged neither in pairs nor in whorls.

Type of the genus.-Primnodendron superbum, new species. 
PRIMNODENDRON SUPERBUM, neW species.

Plate 9, figs. 2, $2 a$; plate 19, fig. 4 .

Colony $31 \mathrm{~cm}$. high, flabellate in general form. The main stem immediately divides into three branches, the central branch forming the main part of the colony. This gives off several lateral branches which, in turn, give off innumerable branchlets. These latter divide so as to form a small rigid tuft of ultimate twigs which together form a compact flattened mass so thick as to look like certain lobate heads of coral, as, for example, Pocillopora or certain flat forms.

Each main branch gives off very numerous branches from all sides, but those from the front and back are shorter than those from the sides and terminate approximately on the same planes in front and back of the colony. All are very closely compacted so that the spaces between the twig terminations are hardly greater than those occupied by the twig ends themselves.

The calyces are rather thickly emplanted on all sides of the twigs, neither in regular whorls nor in regular longitudinal rows, but sometimes approaching the latter. In general there are from 4 to 6 such irregular rows of calyces. The calyces are rather slender curved clubs about $2 \mathrm{~mm}$. long and $1 \mathrm{~mm}$. broad at distal ends. Their openings face directly upward and their margins are ornamented by sharp points from the abaxial and lateral marginal scales. The adaxial marginal scales have very minute points, or none. Two or three horizontal rows of scales below the marginals have similar but smaller points. The eight vertical rows of scales are very plainly marked, and each scale overlaps considerably the base of the one above and ends in a somewhat flaring thin margin with a central point. These points decrease regularly in size from the margin to base of calyx, ending before the latter is reached. There are 6 or 7 scales in each abaxial, abaxial lateral and adaxial lateral row, and 3 or 4 to the adaxials.

The operculum is well developed, each scale bearing a lengthened point much like those around the calyx margin. The adaxial opercular scales are much smaller than the others, and bear no points.

The scales in the cœnenchyma are smaller than those in the calyx walls, and are irregular in shape, forming a mosaic.

Color: The colony is a light yellowish-brown and the axis is black proximally, and lightens distally.

Locality.--Station 4778; Semisopochnoi Island, right tangent $\mathrm{S}$. $45^{\circ} \mathrm{W}$., left tangent S. $12^{\circ} \mathrm{W}$., about 12 miles; $43-33$ fathoms.

A second specimen from the same station is larger than the one described, being $45 \mathrm{~cm}$. high. 
This is the handsomest primnoid in the collection, and shows such marked differences from all other known forms that it forms the type of a very well marked new genus.

Type-specimen.-Cat. No. 30691, U.S.N.M.

\section{Family MURICEID स. $^{1}$}

Axis horny, unjointed, not surrounded by a reguar series of watervascular canals. Calyces various, but never with apertures turned toward branch; a pseudo-operculum present, composed of 8 parts each of which is attached to a tentacle base and is usually composed of 3 spicules forming an acute-angled triangle; collaret present, composed of circular rows of spicules; cœnenchyma usually bristling with spicules which are of exceedingly varied form.

\section{Genus ACANTHOGORGIA Gray (emended by Verrill and, later, by Nutting.)}

Calyces tubular, their walls with spicules arranged en chevron; margins with a crown of points composed of spicules with a distal thorny point and a proximal mass of tubercles or branched processes, the two parts being separated by a bend in the main shaft of the spicule.

\section{ACANTHOGORGIA STRIATA Nutting.}

Acanthogorgia striata Nutring, Gorgonacea of the Siboga Expedition, III, The Muriceidæ, 1910, p. 20.

But a fragment of a branch $3.9 \mathrm{~cm}$. long was secured by the U.S. Fisheries steamer Albatross.

The calyces are rather thickly emplanted on all sides of the branch, in no apparent order. The individual calyces are tubular, with a constriction at the distal end, $2.7 \mathrm{~mm}$. high and $1.3 \mathrm{~mm}$. in diameter. The margin is crowned with an indefinite number of sharp thorny points, usually in small bundles of 3 or 4 , projecting $1 \mathrm{~mm}$. above the margin. The calyx walls are distinctly striated longitudinally on account of the darker brown mesenteries showing through, and are furnished with 8 longitudinal bands of spicules very distinctly arranged en chevron. Inside of the crown of points are a number of similar points some of which lie along the dorsal surfaces of the infolded tentacles.

Spicules: The crown spicules are all of the regular acanthogorgian ty pe, about $1 \mathrm{~mm}$. long, the distal portion smooth and the proximal part not very abruptly bent and tuberculated. The other spicules are small warty spindles with an occasional tuberculate form.

Color: The colony is light-brown, and the calyces are longitudinally striated with 8 darker bands.

1 The definitions for the Muriceidx and the genera included in it in the present work are condensed from the definitions given in the author's Monograph on the Muriceidæ of the Siboga Expedition, 1910. 
Locality.-Station 4936; Sata Misaki Light, N. $21^{\circ}$ E., 5.7 miles; 103 fathoms.

Distribution.-The type-locality is North Celebes, 80 meters; also found by the Siboga Expedition in Banda Sea, 304 meters.

\section{ACANTHOGORGIA FUSCA, new species.}

Plate 10, figs. $1,1 a$; plate 19, fig. 5 .

Colony flabellate in form, very dark in color, $12 \mathrm{~cm}$. in height, and with a spread of $13 \mathrm{~cm}$. The stem is unbranched for $6.1 \mathrm{~cm}$., above which two large branches are given off from each side and a stub on one side. The main branches are closely approximated, and each sends off several irregularly disposed lateral branches which sometimes fork, but usually remain simple. The calyces are very thickly distributed on all sides in indistinct whorls or spirals of 4 or 5 , the distance between calyces being usually considerably less than $1 \mathrm{~mm}$.

The individual calyces are tubular with an abrupt constriction just below the tentacle bases, 1.8 to $2 \mathrm{~mm}$. in height and with a greatest diameter of $1.2 \mathrm{~mm}$. There is a crown of conspicuous points projecting upward and outward from the margin, each point being formed by a single long sharp spicule projecting $1 \mathrm{~mm}$. beyond the margin. The calyx walls are filled with long spindles arranged en chevron in 8 rows, their points projecting upward and outward from the walls. The distal parts of the walls are much lighter in color than the rest and seem to have smaller spicules, excepting those of the margin. Inside the crown are a number of similar thorny spindles bending over the tentacle bases and almost completely concealing the latter when viewed from above.

The spicules are all spindles. Those of the crown are of the regular acanthogorgian type, $1.7 \mathrm{~mm}$. long, with a long, slender, smooth pointed distal part, and a much shorter, densely tuberculate (but not branched) proximal part which is bent at an angle with the distal part and immersed in the calyx wall. The other spicules are bent or curved, rather slender spindles with surfaces covered with not very closely crowded pointed tubercles.

Color: The stem is dark brown, calyces umber-brown lightening on distal parts; crown and tentacular portions appearing white on account of the dense tuft of colorless spicules.

Locality.-Station 4935; Sata Misaki Light, N. 58 E., 4.5 miles; 103 fathoms.

Type-specimen.-Cat. No. 30051, U.S.N.M. 


\section{ACANTHOGORGIA PARADOXA, new species.}

Plate 11, figs. 2, 2a; plate 20, fig..1.

Colony (fragmentary) irregular, $5.5 \mathrm{~cm}$. in height and with a spread of $2.8 \mathrm{~cm}$. The main stem is but $9 \mathrm{~mm}$. long. Immediately above the base it gives off 2 short stubs of branches, $1.8 \mathrm{~cm}$. above this a forked lateral branch is produced, and about $6 \mathrm{~mm}$. above this latter is a branch bearing 2 laterals which are on opposite sides. The calyces are thickly emplanted on all sides of the stem and branches, there sometimes being irregular whorls of about 5, although no regular arrangement is discernible.

The individual calyces are strictly columnar in shape and attain a height of $3 \mathrm{~mm}$. and a diameter of $1.3 \mathrm{~mm}$. The margin is surrounded by a crown of spicules consisting of an irregular number of sharp points projecting upward and outward. Within the crown are a number of other similar points bending over the tentacle bases. The spiculation of the calyx walls is unique in the genus Acanthogorgia. Their surface is covered by a layer of vertical and parallel spindles many of which extend straight from base to crown, their proximal ends even bending and extending for some distance over the cœenenchyma surrounding the calyces. Some of these spindles are nearly $3 \mathrm{~mm}$. long. Inside of these and occasionally showing between them are a number of much smaller spindles which, at least near the distal ends of the calyces, show the en chevron arrangement characteristic of the genus.

Spicules: The crown spicules are of the regular acanthogorgian type, attaining a length of nearly $3 \mathrm{~mm}$. The proximal immersed portion is proportionally larger than in the last species and densely tuberculate, and the distal part has a few distant points and is not so smooth as in the last. The spicules of the outer layer of the calyces and branches are coarse, short, often bent, densely tuberculate spindles sometimes $3 \mathrm{~mm}$. long. Besides these there are the much smaller spindles of the inner layer.

Color: The whole colony is a rather light, clear tan-brown.

Localities.-Station 4890; Ose Saki Light, N. $2^{\circ}$ W., 10 miles; 135 fathoms (type). Station 4894; Ose Saki Light, N. 41 ${ }^{\circ}$ E., 5 miles; 95 fathoms. Station 5070; Ose Saki, S. $8^{\circ} \mathrm{W} ., 1.8$ miles; 108 fathoms (fragment).

Type-specimen.-Cat. No. 30035, U.S.N.M.

This form may need a new genus to include it; but as it substantially agrees with the definition given for Acanthogorgia, it is thought best to place it here. 
Genus ANTHOMURICEA Wright and Studer.

Calyces cylindrical, without a crown of points, walls with spindles arranged en chevron. Operculum conspicuous, 8-rayed, the basal part with small spindles'en chevron.

Spicules without "Stachelplatten."

\section{ANTHOMURICEA ABERRANS, new species.}

Plate 13, figs. $3,3 a$; plate 20 , fig. 2.

Colony flabellate, irregularly branching, $9.7 \mathrm{~cm}$. high and with a spread of $8.5 \mathrm{~cm}$. This stem is $3.4 \mathrm{~mm}$. in diameter, slightly compressed laterally. After sending off four minute lateral branches it forks about $1.2 \mathrm{~cm}$. from its base, into two large branches, both of which send off several irregularly disposed lateral branches which subdivide in the same manner until in one case branching of the fifth order is produced. The ultimate branches are scraggly, something like those of an oak tree. The calyces are often in lateral position, but are on all sides of the terminal parts of the colony. They are as much as $2 \mathrm{~mm}$. apart on main stem and branches, and about $1 \mathrm{~mm}$. apart on the twigs.

The individual calyces are very low verrucæ, but not entirely included although they closely approach this condition when the polyp is in complete retraction. When partly expanded the calyx may even approach the form of a very short tube, or rather circular band or collar, about $0.5 \mathrm{~mm}$. in height and $1.5 \mathrm{~mm}$. broad at base. The calyx walls are filled with simple spindles which are often curved. Some are bent and more or less horizontal, while others are oblique or even vertical. In a dried fragment where the polyp was fairly well expanded the upper part of the calyx wall was armed with spindles arranged plainly en chevron, as in Anthomuricea. The polyp is completely retractile, but often rests with the collaret on the margin. The collaret is well marked but narrow, consisting usually of two or three circular rows of spindles. The operculum is composed of the usual three spindles arranged in an acute-angled triangle, reenforced by others in varying numbers. Each of the long sides of the triangle is often composed of two curved spindles lying side by side, instead of a single one.

Spicules: The spicules of the cœnenchyma are small warty spindles lying haphazard. All spicules in this species are rather slender spindles, often curved and covered moderately well with tubercles, seldom exceeding $1.3 \mathrm{~mm}$. in length, being smaller than in other species of the genus.

Color: The colony is gray; axis yellowish-brown with a faint golden luster. 
Locality.-Station 4987; Kamoi Misaki Light, N. 76 E., 3.2 miles; 59 fathoms.

Type-specimen.-Cat. No. 30037, U.S.N.M.

This species differs from others in the genus in the calyces, which are not truly cylindrical, and in the tendency toward a definite en chevron arrangement in the calyx walls.

\section{Genus MURICEIDES Wright and Studer (emended by Nutting).}

\section{Muriceides Studer+Clematissa STUdER.}

Calyces cylindrical or conical, their walls filled with vertically placed spindles, clubs, disks, tri-radiate forms, etc. No crown of points. Spicules on tentacle bases arranged en chevron.

\section{MURICEIDES CYLINDRICA, new species.}

Plate 11, figs. 1, 1a; plate 20, fig. 3.

Colony straggling in habit, $15 \mathrm{~cm}$. in height, soft and flexible, flattened at branch origins, giving off two ramified branches near its base which are at right angles to the other branches. These latter are on the same plane and are very irregularly disposed, there being 6 on one side and 3 on the other. The calyces are irregularly distributed on the branches, but are ordinarily lateral in position although they are on all sides of the distal twigs. On an average they are about $2 \mathrm{~mm}$. apart, although this varies greatly.

The variation in size of individual calyces is also very great. They are tubular in form and are surmounted by the polyp head, which is relatively large. A typical calyx measures a little over $2 \mathrm{~mm}$. to margin and is $1.7 \mathrm{~mm}$. in diameter, and the mass of tentacles and operculum rises about $2 \mathrm{~mm}$. above this. The walls are filled with rather small, short, much tuberculated spindles vertically arranged and ending in jagged, irregular, not conspicuous points around the margin. The polyps are apparently not retractile, all of them resting with the collaret above the margin. Collaret very strong, composed of several transverse rows of rather small spindles aggregated in a conspicuous band.

The operculum is heavy, composed of numerous rather small spindles arranged en chevron on basal parts of tentacles and lying parallel in vertical bands on distal parts.

These bands are broad and conspicuous, covering the entire dorsal surfaces of the tentacles. The cœnenchyma of stem and branches is covered with small, stout, warty spindles irregularly disposed, but more often longitudinally arranged.

Spicules: These are all spindles, small for this family, those of calyx walls longer and relatively more slender than those of the cœnen- 
chyma, which are often terete forms, closely tuberculated. Small irregular spicules with expanded bases are sometimes seen. Very rarely they are branched.

Color: The colony is dull yellowish-brown, and the spicules are colorless.

Localities.-Station 4781 ; lat. $52^{\circ} 14^{\prime} 30^{\prime \prime}$ N.; long. $174^{\circ} 13^{\prime}$ E.; 482 fathoms (type). ? Station 4895 ; Ose Saki Light, N. $42^{\circ}$ E., 4.7 miles; 95 fathoms.

\section{Type-specimen.-Cat. No: 30046, U.S.N.M.}

In general appearance this species resembles the genus Anthogorgia, but differs notably from that genus in the arrangement of the opercular spindles and in the size of the spicules in general. A specimen from station 4895 appears to belong to this species, but the calyces are much smaller, as if shrunken.

\section{MURICEIDES NIGRA, new species.}

Plate 12, figs. $1,1 a$; plate 20 , fig. 4 .

Colony flabellate, resembling Muricea or Plexaura in general appearance, $17.5 \mathrm{~cm}$. in height and with a spread of $9 \mathrm{~cm}$. The stem is short, and is $6.5 \mathrm{~mm}$. in diameter. A branch is given off $1.7 \mathrm{~mm}$. from its base, and this again branches, throwing off several lateral branchlets, some of which are again divided; $6.6 \mathrm{~cm}$. from its base the stem again divides into two subequal parts each of which bears several lateral branchlets which are directed upward, as in Plexaura. The calyces are rather regularly distributed on all sides of the stem and branches without, however, showing any definite order. They are about $2 \mathrm{~mm}$. apart on distal parts of the colony and more widely separated on the proximal parts.

The individual calyces are tubular, a typical one measuring $3 \mathrm{~mm}$. to its margin, and it has a diameter of $2 \mathrm{~mm}$. Many, however, are much shorter. The walls are filled with quite small spindles, irregularly arranged, but with a strong tendency toward a vertical position. The spicules are smaller than in $M$. cylindrica. The polyps are only partially retractile, resting with their collarets above the margins. The collaret is well marked, with 2 to 4 rows of spicules encircling the polyp just below the tentacle bases. The operculum is dome-shaped, moderately high, composed of spicules arranged en chevron on tentacle bases, and others forming longitudinal bands of 3 or 4 spicules in width on the distal parts of the tentacles. The cœenenchyma bears small spindles arranged longitudinally.

Spicules: These are mostly spindles which are minute for this family, rather closely tuberculated. There are also a few small, irregular tuberculate forms.

Color: The colony (in alcohol) is very dark brown, almost black. The black color is most unusual among the Gorgonacea. This may, 
however, possibly be due to some action of the preservative or other chemical process.

Locality.-Station 4784; East Cape, Attu Island, S. $18^{\circ}$ W., 4 miles; 135 fathoms.

Type-specimen.-Cat. No. 30019, U.S.N.M.

Genus MURICELLA (emended).

Calyces in the form of verrucæ or truncated cones, spicules all spindles vertically arranged except on tentacle bases, where they are en chevron. Calyx margin often showing eight blunt points.

MURICELLA RETICULATA, new species.

Plate 14, figs. 1, 1a; plate 20, fig. 5.

Colony flabellate and reticulate, $24 \mathrm{~cm}$. in height and with a spread of $15.5 \mathrm{~cm}$. The main stem is straight for much of its length, giving off numerous but irregularly disposed lateral branches, laterally compressed except at basal portion, where it is round and $4 \mathrm{~mm}$. in diameter. On the branch-bearing part it is 5 by $3.5 \mathrm{~mm}$. in section. The main branches are likewise compressed in the same manner, especially in their proximal parts. Those on one side are alternating stubs and large branches which often again divide, usually in a pinnate manner, the ultimate twigs often anastomosing with those of adjacent branches. Branchings of the fourth order are sometimes attained. The branches are about $5 \mathrm{~cm}$. apart. The calyces are thickly distributed on all sides of the branches, but are less abundant on the back of the colony and most abundant on distal parts of the twigs, where they are usually less than $1 \mathrm{~mm}$. apart.

The individual calyces are low cones or short tubes according to the state of retraction of the polyps. A typical calyx measures $1 \mathrm{~mm}$. high to the collaret and is $1.3 \mathrm{~mm}$. broad at the base; but they vary much in size. Their walls are covered with rather heavy warty spindles which often encircle the basal part, but may lie in almost any direction. On the distal parts the spindles are smaller, tending to be vertical, sometimes approaching an en chevron arrangement, forming blunt points which arise at regular intervals around the margin. Tentacles armed with strong spindles which are arranged en chevron proximally and are longitudinal distally.

Spicules: Besides the spindles in the calyx walls and polyps, there are two sorts found in the cœnenchyma: 1, very large, heavy tuberculate spindles which are placed often at distant intervals and sometimes attain a length of $2.5 \mathrm{~mm}$; and 2, spindles of much smaller size, often lying deeper on stem and branches, usually longitudinally disposed except where they encircle the calyx bases.

Color: Colony deep chocolate-brown, silvered by the large colorless spicules. 
Localities.-Station 4936; Sata Misaki Light, N. $21^{\circ}$ E., 5.7 miles; 103 fathoms (type). Station 4893; Ose Saki Light, N. $29^{\circ}$ E., 5.5 miles; 106-95 fathoms.

Type-specimen.-Cat. No. 30045, U.S.N.M.

This species bears a superficial resemblance to Versluysia ramosa (Thomson and Henderson) ${ }^{1}$; but the spiculation of calyces and tentacles shows it to be a Muricella.

\section{MURICELLA ABNORMALIS, new species.}

Plate 11, figs. $3,3 a$; plate 20 , fig. 6 .

Colony (incomplete) consisting of three simple, straight, cylindrical branches, joined at their bases. The largest is $7.3 \mathrm{~cm}$. in length and has a diameter of $4.5 \mathrm{~mm}$. The general aspect of the branch is not at all like the typical Muricella, but more like the genus Thesea. The spiculation, however, shows that it can not belong to the latter genus. The calyces are thickly distributed on all sides, being seldom more than $1.5 \mathrm{~mm}$. apart and usually much closer.

The individual calyces are short cylinders or truncated cones, a typical one measuring $2 \mathrm{~mm}$. in height and $1.9 \mathrm{~mm}$. in diameter. Their walls are filled with loosely embedded long slender spindles, much more delicate than is usual in this genus, vertically disposed in proximal parts and with their distal ends approximated in an en chevron arrangement in distal part. Some of these spindles reach from base to beyond the margin of the calyx. Margin with 8 triangular points, usually equidistant, formed by the distal ends of one or more of these spindles.

The polyps are retractile, and their spiculation differs from most species of this genus. There is a distinct, strong collaret composed of two or more circular rows of long, often curved, spindles. The operculum is composed mainly, if not exclusively, of three spindles which are so disposed as to form an acute-angled triangle pointing toward the center of the operculum. This is quite different from other species in the genus.

Spicules: These are all slender, often bent or curved spindles; sometimes attaining a length of $2 \mathrm{~mm}$., but much more slender than is usual in this genus. Their surface is covered with sharply pointed tubercles which are much more thickly distributed on the larger than on the smaller spindles. These spindles, especially when curved, closely resemble many found in the genus Acanthogorgia.

Color: Very light yellowish or creamy-white. The axis is brown. Locality.-Station 5070; Ose Saki, S. $8^{\circ}$ W., 1.8 miles; 108 fathoms. Type-specimen.-Cat. No. 30093, U.S.N.M.

It is with great hesitation that I place this species in the genus Muricella on account of the peculiar formation of the pseudo-operculum. Otherwise it goes into the genus easily enough. 
Genus THESEA Duchassaing and Michelotti (modified by Nutting).

Calyces verruciform, their walls filled with broad scale-like spindles armed with thorny processes on one side only, the opposite edge being tuberculate. Scales imbricating, the thorny processes being uppermost and overlapping the lower edges of other spicules. Heavy ordinary spindles are also present.

\section{THESEA PLACODERMA Nutting.}

Thesea placoderma Nutring, Muriceidæ of the Siboga Expedition, 1910, p. 54.

Colony flabellate, not reticulate, $7.3 \mathrm{~cm}$. in height and with a spread of $4.6 \mathrm{~cm}$.

The main stem is $2 \mathrm{~mm}$. in diameter and gives off a few stubs of branches on one side and a number of simple twigs and two compound branches on the other. Branches of the third order sometimes produced. The distance between branches varies considerably, perhaps averaging 4 to $6 \mathrm{~mm}$. The calyces are mostly lateral, with a few on front and back, particularly on distal parts. They are ordinarily less than $1 \mathrm{~mm}$. apart.

The individual calyces are low verrucæ of variable height, usually not exceeding $1 \mathrm{~mm}$., and about $1.3 \mathrm{~mm}$. in diameter. Their walls are filled with heavy plates or spindles with their upper edges armed with a row of jagged teeth. These scales are imbricating, the teeth pointing upward and outward and surrounding the margin with an irregular series of points. The polyps are retracted to their collarets. The operculum is heavy, each flap being composed mainly of two long spindles with their proximal ends divaricated and their distal ends approximated to form a point near the center of the mass of infolded tentacles.

Spicules: These are of the characteristic Thesea type, as described above. The conenchyma of stem and branches is covered with scalelike plates with irregular, often jagged, edges.

Color: The axis is dark brown, and the general color of the colony is grayish-brown.

Localities.-Station 4894; Ose Saki Light, N. $41^{\circ}$ E., 5 miles; 95 fathoms. Station 4936; Sata Misaki Light, N. $21^{\circ}$ E., 5.7 miles; 103 fathoms.

The type-locality is in Flores Sea, East Indies, 73 meters.

Genus ACIS Duchassaing and Michelotti (modified by Nutting).

Colony branched, calyces varying in form, their walls and the tentacle bases with spindles not en chevron. Spicules of the cœnenchyma very heavy spindles or plates, their edges often fitted as in mosaic. 


\section{ACIS SQUAMATA Nutting.}

Acis squamata Nutring, Muriceidæ of the Siboga Expedition, 1910, p. 42.

Colony flabellate, very profusely branched, $6.2 \mathrm{~cm}$. long and with a spread of $5.2 \mathrm{~cm}$. The base is lacking, the part preserved consisting of two main branches which anastomose distally, their basal parts being free. The larger branches are three in number, sending off numerous side branches some of which again divide until branches of the fourth order are produced. Side branches very closely approximated, often not more than $1 \mathrm{~mm}$. apart. The calyces are all anterior or antero-lateral, mostly the latter, close set, less than $1 \mathrm{~mm}$. apart and often contiguous.

The individual calyces are variable in shape, being low verrucæ, short tubes, or truncated cones. A typical one measures $1.7 \mathrm{~mm}$. in height and $2 \mathrm{~mm}$. in diameter. Their walls are armed with large squarish plates often in two, sometimes in three, series. The transverse diameter of these plates is usually longer than the vertical, and their free edges are thin and finely ctenate, the other edges being fitted together forming a complete covering. The free edges are usually rounded. The distal row looks like an operculum composed of a flattened scale for each tentacle, but dissection shows that the true operculum is under these and is composed of two comparatively slender spindles lying longitudinally along the dorsal surfaces of the tentacles. The cœnenchyma is covered with squarish or polygonal plates, their edges nicely fitted. Those on the anterior surface of the colony are much larger than the others, sometimes reaching a length of $4 \mathrm{~mm}$. Those on the back of the colony are small, squarish or polygonal plates averaging not more than $1 \mathrm{~mm}$. in diameter.

The spicules have already been described. They are the heaviest that the writer has seen in the Gorgonacea.

Color: The axis is dark brown, and the polyps are dark umberbrown with a slight purplish tinge. The general surface is white, but the dusky color of the axis and polyps shows through somewhat, imparting a slightly bluish tinge.

Locality.- - Station 4936; Sata Misaki Light, N. $21^{\circ}$ E., 5.7 miles; 103 fathoms.

The type-locality is Dutch East Indies, near Saleyer Island, 400 meters.

The U.S. Fisheries steamer Albatross specimens agree with the type except in the color of axis and polyps, which, in the type, are much lighter. This may be due partly to the fact that the Siboga material has been longer preserved in alcohol than that secured by the Albatross.

$48702^{\circ}$-Proc.N.M.vol.43-12-6 


\section{ACIS SPINIFERA, new species.}

\section{Plate 13, figs. 2, $2 a$; plate 21, fig. 1.}

Colony flabellate, straggling in habit, $9.6 \mathrm{~cm}$. in height and with a spread of $10 \mathrm{~cm}$. The main stem is erect, slightly sinuous, $2.5 \mathrm{~mm}$. in diameter. The first branch arises $1.7 \mathrm{~cm}$. from the base. The branches are lateral and, for the most part, sub-opposite, 6 on one side and 7 on the other, about $9 \mathrm{~mm}$. apart on the average, and 1.8 $\mathrm{mm}$. in diameter. Some of them give off branchlets to the fourth order. The calyces are thickly emplanted on all sides of the stem and branches, often less than $1 \mathrm{~mm}$. apart.

The individual calyces are in the form of short cylinders or broadly truncated cones, a typical one measuring $2.4 \mathrm{~mm}$. in height to top of spines and $2 \mathrm{~mm}$. broad at base. The walls are covered with broad scale-like plates, usually broader than long, imbricating. Those of the lower row have free rounded margins which are finely ctenate and overlap the plates of the upper row. The marginal plates have broad bases, the sides of which overlap and are suddenly narrowed distally into prominent spine-like points which surround the margin with a conspicuous crown of points which are somewhat spatulate and often project more than $1 \mathrm{~mm}$. beyond the margin. Usually there are but two rows of plates on each calyx wall, although the edges of the plates of the surrounding cœnenchyma may extend somewhat upward over the basal part of the calyx. The collaret is well developed, consisting of two or more rows of transverse spicules. The operculum is regular, composed of three spindles forming an acute angled triangle.

There are two layers of spicules on the stem and branches. First, an outer layer of heavy plates or scales, usually polygonal, of various shapes and sizes, sometimes with edges nicely fitted; but the larger ones often have the edges more or less imbricated, and are rarely as large as the calyx spicules. Second, a very thin delicate layer of minute rather sparsely distributed spindles.

Spicules: Mostly polygonal plates of various shapes and sizes, the largest usually curved to fit the calyx or branch, attaining a size of 2.5 by $2 \mathrm{~mm}$. The spine scales of the margin are often 2 by $1 \mathrm{~mm}$. There are also spindles from the collaret and operculum, and minute ones from the inner layer of the cœnenchyma.

Color: The colony is tan-brown throughout, and the axis dark golden-brown.

Locality.-Station 4936; Sata Misaki Light, N. $21^{\circ}$ E., 5.7 miles; 103 fathoms.

Type-specimen.-Cat. No. 30088, U.S.N.M. 
This form resembles Acis spinosa Thomson and Simpson, ${ }^{1}$ but differs in color, and has much larger spicules, according to the measurements given by these authors.

Genus PLACOGORGIA Wright and Studer (emended by Nutting).

Colony flabellate, sometimes reticulate; calyces low cones or verrucæ, their walls filled with imbricating disks or "Stachelplatten;" operculum composed of three spindles forming an acute-angled triangle in each opercular flap.

PLACOGORGIA JAPONICA, new species.

Plate 13, figs. 1, 1a; plate 21, fig. 2.

Colony (incomplete) $8.4 \mathrm{~cm}$. long. Stem $6 \mathrm{~mm}$. wide at base above which it forks into two very unequal main branches, the smaller of which forms the main part of the specimen. This again forks 1.6 $\mathrm{cm}$. from its origin, and but one of the resultant branches remains. Above this the stem is unbranched for $2.5 \mathrm{~cm}$., when it again forks. The ultimate branchlets are $3 \mathrm{~mm}$. in diameter. The calyces are distributed on all sides, more thickly on the distal parts, forming clusters on the ends of the twigs, and sometimes being as much as $2.5 \mathrm{~mm}$. apart on the proximal parts of the colony.

The individual calyces are low, dome-like verrucæ, a typical one measuring $2.1 \mathrm{~mm}$. in diameter at the base. The calyx walls are filled with spindles or long flattened plates of various forms and variously arranged. Sometimes these plates encircle the base and at others they are all vertical in position, looking like strong spindles. In other cases the plates are haphazard in position, the distal ones with a tendency to be vertical. These vertical spicules are often triangular plates with comparatively straight edges, their acute angles forming a series of irregular points around the margin.

The polyp is retractile, but often rests with the collaret just above the calyx margin. This (the collaret) is strong, composed of two or three rows of encircling spindles. The operculum is composed of three spindles forming an acute-angled triangle on each flap. The points of the triangles thus formed reach almost to the center of the mass of infolded tentacles.

Spicules: These are mostly heavy plates with various contours, but never forked nor conspicuously branched. They are usually oblong, sometimes squarish, triangular, or roughly oval in outline, seldom exceeding $2 \mathrm{~mm}$. in length, and have their corners rounded. There are a few small spindles. 
Color: The axis is brown proximally, lightening distally; colony in general apparently dark brown, but this seems to be accidental, as the spicules when in situ are covered with black or dark-brown specks which do not appear in the cleaned spicules. The polyps are umberbrown.

Locatities.-Station 4935; Sata Misaki Light, N. $58^{\circ}$ E., 4.5 miles; 103 fathoms. Station 4936; Sata Misaki Light, N. $21^{\circ}$ E., 5.7 miles; 103 fathoms. Station 5070 (type); Ose Saki, S. $8^{\circ}$ W., 1.8 miles; 108 fathoms.

Type-specimen.-Cat. No. 30096, U.S.N.M.

This species approaches Muricella, on the one hand, in the strong spindles, and Acis in some of the plate-like spicules. It bears some resemblance to Acanthomuricea ramosa Thomson and Henderson. ${ }^{1}$ This species, however, will go very well into the genus Placogorgia of authors.

Genus VILLOGORGIA Duchassaing and Michelotti (emended by Wright and Studer).

Colony flabellate, often reticulate; cœnenchyma thin; calyces short; cylinders with an operculum in which each flap is composed of three spindles arranged in an acute-angled triangle. Spicules mainly triradiate or quadriradiate forms, or "Stachelplatten."

VILLOGORGIA BRUNNEA, new species.

Plate 12 , figs. 2, $2 a$; plate 21 , fig. 3.

Colony flabellate and reticulate, $5.8 \mathrm{~cm}$. high and with a spread of 4.9 $\mathrm{cm}$. Main stem $2 \mathrm{~mm}$. in diameter; $6 \mathrm{~mm}$. from its base it forks into two subequal branches, offshoots of which anastomose. Branchlets opposite and irregularly alternate, some of the distal ones again branching. The distance between branchlets averages about $5 \mathrm{~mm}$. The calyces are mainly lateral, but some are on the front of the colony, irregularly alternate on antero-lateral surface, about 1:5 mm. apart.

The individual calyces are in the form of short cylinders, a typical one measuring $1.3 \mathrm{~mm}$. high to margin and $1.5 \mathrm{~mm}$. broad. They are often more like broadly truncated cones. Their walls are filled with small triradiate and quadriradiate spicules, the points of which are inconspicuous but which are directed slightly upward and outward from the walls. There are no marginal points. The polyps usually rest with their collarets on the margin. Collarets well marked, consisting of two or more circular rows of spindles. Operculum formed mainly of three spindles in the usual position for this genus, forming an acute-angled triangle pointing toward the center of the domeshaped tentacular mass. There are usually a few accessory spicules parallel with the others. 
Spicules: These are mainly small triradiate and quadriradiate forms and butterfly shapes. Irregularly branched and radiate forms, with a few true spindles and a few clubs and daggers are found.

Color: A rather lively yellowish-brown.

Locality.-Station 4936; Sata Misaki Light, N. $21^{\circ}$ E., 5.7 miles; 103 fathoms.

Type-specimen.-Cat. No. 30098, U.S.N.M.

Another specimen from the same station is characterized by much more prominent spicules, those on the calyx walls forming evident points.

\section{Genus ELASMOGORGIA Wright and Studer (emerided).}

Colony simple or sparingly branched, very slender and flexible; calyces very low and distant verrucæ; spicules medium-sized spindles, not attaining the size of those in Muricella or Acis.

ELASMOGORGIA FILIFORMIS Wright and Studer.

Elasmogorgia filiformis WrIGHT and StUder, Challenger Reports, the Alcyonaria, 1889, p. 133.

Colony an unbranched stem, very slender and flexible, $47 \mathrm{~cm}$. long, diameter $1 \mathrm{~mm}$.

Although in places the calyces tend to be lateral and alternate, they are really on all sides of the stem, somewhat distant but irregularly spaced, being about $3 \mathrm{~mm}$. apart.

The individual calyces are low conical verrucæ, about $0.7 \mathrm{~mm}$. high and with a basal diameter of about $1.8 \mathrm{~mm}$., although this is hard to estimate because the calyx walls slope so insensibly into the general surface of the cœnenchyma. The calyx walls are filled with small short spindles arranged transversely on lower parts and a few small ones vertically placed around the margin, their ends forming an inconspicuous circlet of points. The polyps are usually completely retracted and almost entirely concealed by the indrawn margins. Some of them, however, rest with the collaret on the margin. The collaret is well marked, consisting of two or more circular rows of spindles. The operculum is strong, each flap consisting of three spindles forming an acute-angled triangle, rcenforced by others lying parallel to these, or disposed longitudinally on the distal parts of the tentacles.

The ccenenchyma is filled with a compact layer of short stout spindles lying lengthwise of the stem.

Spicules: These are all rather small spindles for this family, their surface covered with conspicuous verrucæ.

Color: The colony is rather dark brown; axis almost black.

Locality.-Station 4837; Tateisha Zaki Light, S. 53 E., 8 miles; 57 fathoms. 
General distribution.-Type-locality, Arafura Sea, 28 fathoms. Reported by Nutting from California coast, 75-134 fathoms, and Dutch East Indies, 112 meters.

ELASMOGORGIA RAMOSA, new species.

Plate 15, figs. 2, $2 a$; plate 21, fig. 4 .

Colony subflabellate in form, $12.5 \mathrm{~cm}$. in height and with a spread of $8.5 \mathrm{~cm}$. Stem sinuous, $3.2 \mathrm{~mm}$. in diameter, giving off irregularly disposed lateral branches at varying distances. Some of these latter branch until branchings of the fourth order are attained.

The branches are slightly clavate at ends, with a distal diameter of $2.3 \mathrm{~mm}$, and near base of $1.7 \mathrm{~mm}$. The calyces are entirely immersed, so that merely the mouths are evident as oval openings in the general surface of the cœnenchyma. The calyx walls are not differentiated from cœnenchyma and are covered with short terete spindles with ctenate edges, sometimes imbricating. The operculum is irregular with mostly longitudinal spicules; sometimes there is an approach to the regular arrangement of three forming an acute-angled triangle.

The spicules are all spindles which are short, small for this family, and covered with verrucæ.

Color: The colony is very light grayish-brown.

Locality.-Station 4935; Sata Misaki Light, N. $58^{\circ}$ E., 4.5 miles; 103 fathoms.

Type-specimen.-Cat. No. 30043, U.S.N.M.

The regular branching seems to be a character which is sufficient to constitute a new species.

\section{Genus MENELLA Gray (emended by Nutting).}

Colony sparingly branched; cœnenchyma thick; calyces included, elliptical in cross section. When the polyps are retracted there is a series of 8 soft lobes inside of the calyx margins. Spicules various, true spindles being rare.

\section{MENELLA INDICA Gray.}

(The original reference is not accessible to the writer, who identifies this species on the strength of the description given by Wright and Studer, Challenger Reports, the Alcyonaria, 1889, p. Lrv.)

Colony an unbranched cylindrical stem, $29.5 \mathrm{~cm}$. long, average diameter $1.8 \mathrm{~mm}$., but the diameter near the clavate end is $2.1 \mathrm{~mm}$. Calyces distributed rather unevenly on all sides, the low verrucæ fading almost insensibly into the general surface and making it hard to determine their limits. Two mm. is a common distance from summit to summit. The individual calyces are almost entirely included, distinctly oval in section, less than $1 \mathrm{~mm}$. in height. Diameters 1.3 
and $1.8 \mathrm{~mm}$. The calyx walls are studded with sharp, conspicuous points projecting upward, particularly evident around the margin, where they form a crown of numerous points. Similar projections give a bristling appearance to the entire cœnenchyma. The polyps are completely retractile and are all sunken so that the operculum is considerably below the margin. The operculum is composed of delicate spindles, two of which are nearly parallel along the dorsum of each tentacle.

Spicules: These are exceedingly varied in form. The most conspicuous is a quadriradiate form consisting of a triradiate base from which a much larger, straight, comparatively smooth point arises. This is the form that furnishes the bristling points mentioned above. There are also triradiate and multiradiate forms, symmetrical and unsymmetrical, a few five-pointed stars and ordinary spindles.

Color: The colony is rather dark grayish-brown; the spicules colorless.

Locality.-Station 5071; Ose Saki Light, S. 53.5 W., 2.6 miles; 57 fathoms.

General distribution.-The type-locality is "india" (Gray).

The U.S. Fisheries steamer Albatross specimen agrees well with the description given by Wright and Studer. The stem is very flexible, so that it can be tightly coiled without breaking, even after several years immersion in alcohol.

\section{Genus BEBRYCE Philippi (modified by Kölliker).}

Cœnenchyma very thin, the outer layer filled with peculiar spicules which are shaped like a collar button and have usually frilled or scalloped margins. They usually have a darker center and lighter marginal area when in situ.

\section{BEBRYCE HICKSONI Thomson and Henderson.}

Bebryce hicksoni Thomson and Henderson, Ceylon Pearl Oyster Reports; Supplementary Reports, No. XX, 1905, p. 294.

Colony flabellate, rudely pinnate, $10.2 \mathrm{~cm}$. high and with a spread of about $9.4 \mathrm{~cm}$. The main stem is straight and, like the main branches, is distinctly flattened, being $1.5 \mathrm{~mm}$. by $2 \mathrm{~mm}$. in section. The branches are all lateral and in the same plane. One branch is compound and the others are simple on one side of the colony, and there are two compound branches and two short stubs on the other side. Branchings of the fourth order are produced, but there are no anastomoses and no terminal calyces. The calyces are almost all lateral in position, except near the distal ends of twigs, where they are on all sides. Generally they are either alternate or opposite in arrangement.

The individual calyces are conical or dome-shaped; a typical one measures $1.2 \mathrm{~mm}$. in height and $2 \mathrm{~mm}$. in diameter. Their walls are 
filled with small round disks with darker centers and lighter edges. The polyps are retractile, with well-marked collarets consisting of usually three wary bands of spicules, the convexities lying at the tentacle bases. The operculum is strong, composed of the usual three spindles forming an acute-angled triangle reenforced by other similar spindles, some of which lie along the dorsal surfaces of the tentacles.

Spicules: These are of the characteristic "collar-button" type of this genus, the central stalk or pillar between the two expanded portions being rather longer than in other species, and the edges of the lower, or larger, disks being frilled. There are also a few slender, tuberculate, and often curved spindles.

Locality.-Station 4935; Sata Misaki Light, N. 58 E., 4.5 miles; 103 fathoms.

General distribution.-Type-locality, Ceylon Seas; also reported from the Dutch East Indies (Nutting).

\section{Family PLEXAURID正.}

Axis composed of lime salts and corneous matter, not in regular segments; calyces often included, found on all sides of the stem and branches; spicules various, often club-shaped; cœnenchyma thick, with a regular series of large primary water-vascular canals arranged around the axis cylinder.

\section{Genus EUPLEXAURA Verrill (emended).}

Axis consisting of a horny core surrounded by a thick cylinder of horny material extensively impregnated with calcareous matter. Calyces rather large for this family. Spicules mostly short, warty spindles and small crosses.

\section{EUPLEXAURA PINNATA Wright and Studer.}

Euplexaura pinnata WRIGHT and STUDER, Challenger Reports, the Alcyonaria, 1889, p. 144.

Colony subflabellate, straggling in habit. Stem round, $4 \mathrm{~mm}$. thick, unbranched for $4.8 \mathrm{~cm}$. of its length. It then gives off a pair of opposite branches which attain branchings of the fourth order. Above this a number of lateral branches are given off, some opposite, some subopposite and some alternate; all rather distant, the distance varying from $1 \mathrm{~cm}$. to $2.3 \mathrm{~cm}$. The branches are slightly clavate at their ends and have a diameter of about $2.5 \mathrm{~mm}$. The calyces are fairly regularly distributed on all sides of the stem and branches and are completely included in the cœnenchyma, their oval openings alone indicating their presence aside from a slight tumidity around the margins. They are about $1.8 \mathrm{~mm}$. from center to center. The polyps are completely rectractile. The tentacles bear longitudinally disposed curved spindles. 
Spicules: These are all small ovate or terete forms; densely tuberculate clubs, double clubs and sometimes double wheels or collarbutton forms, reminding one of the genus Bebryce, are also found.

Color: The colony is grayish-brown.

Locality.-Station 4894; Ose Saki Light, N. $41^{\circ}$ E., 5 miles; 95 fathoms.

Type-locality.-Kobe, Japan, 8 and 50 fathoms.

The primary water-vascular canals are not easily made out, and this species is hard to differentiate from some Muriceidæ, such as Bebryce.

Family ISID $\approx$ Gray (modified by Wright and Studer).

Axis composed of alternating calcareous and horny joints, both of which are amorphous.

\section{Genus ACANELLA Gray (amended by Verrill).}

Branches arising from the short horny internodes of the axis. No external layer of scale-like spicules.

\section{ACANELLA NORMANI Verrill.}

Acanella normani VerrIL, Amer. Journ. Sci. and Arts, vol. 16, 1878, p. 212.

Colony erect, tree-like, $16 \mathrm{~cm}$. high. The root bears heavy branching calcareous processes. The stem with lower nodes shorter and the upper longer, dividing into three main branches about $3 \mathrm{~cm}$. from its base. Each of these gives off usually two, sometimes three branchlets in verticils from its horny nodes. Branchings to the fourth order are attained. The cœenenchyma is thin. The polyps are uniserial and distant on proximal parts of the branches, none on the stem and larger branches, often about $4 \mathrm{~mm}$. apart, sometimes opposite, more closely crowded on distal parts where the terminal ones are often in pairs and larger than the others, sometimes attaining a height of $4.5 \mathrm{~mm}$.

The calyces are variable in shape, sometimes cylindrical, sometimes almost obconical as if on pedicels. Their walls are armed with long: sharp spindles, which often project far beyond the margin in eight points. Some of these spicules on the outer side of calyx are rery large and strong, running the entire length of the calyx and attaining a length of $3.5 \mathrm{~mm}$. They are often curved and pass obliquely partly around the calyx walls. Their surfaces are covered with minute spinules, as described by Verrill.

Color: The colony is ivory-white with a brownish cast. Polyps golden-brown.

Locality.-Station 4956; Mizunoko Shima Light, N. $22^{\circ}$ W., 33 miles; 720 fathoms. 
General distribution.-Type-locality, Atlantic coast of North America, at considerable depths.

\section{Genus BATHYGORGIA Wright and Studer.}

Spicules of polyps and cœnenchyma bar-like forms with turgid rounded ends, often biclavate.

\section{BATHYGORGIA PROFUNDA Wright and Studer.}

Bathygorgia profunda WRIGHT and Studer, Challenger Reports, the Alcyonaria, 1889, p. 32.

A fragment secured by the U. S. Fisheries steamer Albatross evidently belongs to this species. It is $11.4 \mathrm{~cm}$. long, and consists mainly of two stems or branches which seem to adhere throughout, a condition which is probably accidental or abnormal.

The longest calcareous joint is $4.2 \mathrm{~cm}$. long. The horny joints are very short. The calyces are distant, unequally distributed on all sides of the stem or branch, and are spaced about $7 \mathrm{~mm}$. apart. There is a small branch given off from near the top of one of the calcareous joints, the polyps vary greatly in size, one of the largest being $4 \mathrm{~mm}$. in height with a diameter of $1.5 \mathrm{~mm}$., somewhat larger distally. There are a number of large, biclavate spicules or bars with enlarged ends. These bar-like forms are mostly longitudinal, but may be oblique on the basal part of the body. They seem to be stuck on to the surface of the cœnenchyma, and attain a length of $2 \mathrm{~mm}$. The upper part of calyx walls and bases of the tentacles bear smaller spicules of the same shape, usually longitudinal in position, but often criss-cross. The dorsal surface of the tentacle on median parts is covered with small bar-like spindles which are mainly transverse.

Spicules: These are all bar-like forms, with turgid ends and surfaces irregularly striated and bearing minute points.

The cœnenchyma is thin and contains numerous minute spicules of the same type.

Color: Orange-brown, with the axis showing plainly through the cœnenchyma. The polyps are dark brown, silvered by the spicules.

Locality.--Station 4766; Koniuji Island, S. 22.5 W., 27 miles; 1,766 fathoms.

Type-locality.-Between Yokohama and the Sandwich Islands, 2,300 fathoms.

Genus CERATOISIS Wright.

Calyces with a crown of needle-like spicules; axis simple or branched; cœnenchyma and often the calyces with oblong lenticular or oval scales with comparatively smooth surfaces. 
CERATOISIS PAUCISPINOSA Wright and Studer.

Ceratoisis paucispinosa WRIGHT and STUDER, Challenger Reports, the Alcyonaria, 1889, p. 28.

A few fragments are ascribed to this species. The largest is a denuded axis $13 \mathrm{~cm}$. long; longest joint, $2.4 \mathrm{~cm}$; diameter, $1.6 \mathrm{~mm}$. The horny joints are very short.

Another fragment has a few polyps. The calyces are long and slender, curved basally so as to lie along the stem facing upward. Length to tip of spines, $6.5 \mathrm{~mm}$; diameter at margin, $1.8 \mathrm{~mm}$; near base, $1.3 \mathrm{~mm}$. There are a few remarkably long pointed spines lying vertically in the polyp walls, some of which have their points projecting beyond the margin, forming a very conspicuous crown of points. One of these spicules in $4.5 \mathrm{~mm}$. long. Similar spicules lying loose in the bottle measure $5 \mathrm{~mm}$. in length.

The cœnenchyma of the stem contains a number of sparsely scattered comparatively minute bar-like spicules.

Locality.-Station 5083; Omai Saki Light, N. $23.5^{\circ}$ E., 34.5 miles; 624 fathoms.

General distribution.-Type-locality, Hyalonema Grounds, off Japan, 345 fathoms; Hawaiian region (Nutting); Dutch East Indies (Nutting).

CERATOISIS PHILIPPINENSIS Wright and Studer.

Ceratoisis philippinesis WRIGHT and STUDER, Challenger Reports, the Alcyonaria, 1889 , p. 27.

A number of large fragments with the cœnenchyma and calyces well preserved are included in the U. S. Fisheries steamer Albatross material. This species breaks so easily at the internodes that it is unlikely that complete specimens will be secured by dredging.

There is no evidence of branching, and it is likely that in life the species is a very beautiful rod-like form.

The largest fragment is $13 \mathrm{~cm}$. long and has a diameter of 1.7 $\mathrm{cm}$., including the calyces. One large node is $5.2 \mathrm{~cm}$. long and $4 \mathrm{~mm}$. in diameter, without the cenenchyma. The surface is smooth, with an appearance of longitudinal striation, and the axis is hollow except at the ends.

The calyces are densely aggregated on all sides of the stem, not in definite verticils but in about ten very irregular longitudinal rows; and quite contiguous.

The individual calyces have long cylindrical bodies tapering below into a thick pedicel. Sometimes they are as much as $1 \mathrm{~cm}$. high to the top of the mass of infolded tentacles. Around the margin there is a regular series of rod-like white spicules alternating with the eight tentacle bases, but not projecting appreciably beyond the tentacles. These spicules are sometimes $3 \mathrm{~mm}$. long and are entirely rod-like in 
form. They have a thick coating of cœnenchyma when the polyps are well preserved. The tentacles have a few irregularly disposed, but mostly longitudinal, much smaller lenticular spicules on the dorsal surface. They often occur in two irregular longitudinal rows. The dorsal surfaces of the pinnules bear minute spicules.

Color: The colcny is a bright orange-brown. The axis is white, with the horny nodes brown.

Locality.-Station 5029; lat. $48^{\circ} 22^{\prime} 30^{\prime \prime}$ N.; long. $145^{\circ} 43^{\prime} 30^{\prime \prime}$ E.; 440 fathoms.

General distribution.-Type-locality, off the Philippines, 82 fathoms; Dutch East Indies (Nutting).

\section{Section SCLERAXONIA.}

Axis composed of calcareous spicules which are either free or fused into a more or less solid mass.

\section{Family MELITODIDAE.}

Axis composed of alternating horny and calcareous joints both of which have a sclerogorgic basis with free or fused spicules.

\section{Genus MELITODES Verrill.}

Colony branched and reticulate; cœnenchyma with an outer layer of spiny spindles or half-sided spindles. Verrucæ rather prominent.

\section{MELITODES DICHOTOMA (Pallas).}

Isis dichotoma Pallas, Elenchus Zoophytorum, 1766, p. 229.

Colony flabellate in form, the base lacking, $11.3 \mathrm{~cm}$. long and with a spread of $6 \mathrm{~cm}$. The main stem is composed of short, alternating horny nodes and calcareous internodes, the former being more swollen. The unbranched portion of the stem is about $4 \mathrm{~cm}$. long, S-shaped. The diameter of the nodes is about $5.5 \mathrm{~mm}$. and of the internodes $3.8 \mathrm{~mm}$.

The branching is dichotomous as a rule, dividing sometimes until the sixth order of branchings are produced. The branches and branchlets gradually decrease in size. The horny nodes at bifurcations from $8.5 \mathrm{~mm}$. to $2.5 \mathrm{~mm}$. apart. There are a few anastomoses in the distal parts of the colony. The calyces are lateral, alternate or opposite as a rule, although they are not infrequently found on the front of the colony, often contiguous.

The individual calyces are low, dome-shaped verrucæ usually about $1 \mathrm{~mm}$. in height and $1.6 \mathrm{~mm}$. in diameter at the base. Their walls are filled with spicules which appear like ctenate scales on superficial view, but are really red spindles which are often curved and from the convex side of which heavy, sometimes branched, 
tubercles arise. These convex edges are what look like ctenate and often imbricating scales on superficial view. There are also many terete spindles, clubs and other forms.

The polyps are completely retractile, the collaret well developed. A pseudo-operculum much like that found in the Muriceidæ is formed by numerous white, often curved spindles arranged longitudinally on the dorsal surfaces of the tentacles and assuming an en chevron arrangement on their basal parts.

The cœnenchyma is thick, encrusted with spicules such as are found on the calyx walls.

Color: The colony is brick red and the polyps colorless, in alcohol. Some of the fragments from station 4808 are pink, others white, others yellowish The pink ones have the polyp spicules yellow.

Localities.-Station 4808; Cape Tsiuka, S. $61^{\circ}$ W., 10.6 miles; 47 fathoms. Station 4890; Ose Saki Light, N. $2^{\circ}$ W., 10 miles; 135 fathoms. Station 4893; Ose Saki Light, N. $29^{\circ}$ E., 5.5 miles; 106 fathoms. Station 4935; Sata Misaki Light, N. $58^{\circ}$ E., 4.5 miles; 103 fathoms. Station 5070; Ose Saki, S. $8^{\circ}$ W., 1.8 miles; 108 fathoms. General distribution.-Type-locality? (Pallas). Found by the Chatlenger in Torres Strait, and reported by Ridley from South Africa.

Possibly an adequate amount of material and complete specimens would enable one to separate this species into definite groups; but with the material at hand this is impracticable.

\section{Genus PARISIS Verrill (emended by Studer.)}

Colony branched, the branches arising from the calcareous segments; calyces prominent; spicules of irregular forms but constituting a tesselated pavement on the surface of the conenchyma.

PARISIS FRUTICOSA Verrill.

Parisis fruticosa Verrmu, Bull. Mus. Comp. Zoöl., vol. 1, 1864, p. 37 .

The specimens are fragmentary. The largest is a branch, flabellate in form, $6.4 \mathrm{~cm}$. long and $2.8 \mathrm{~mm}$. in diameter; $1.5 \mathrm{~cm}$. from its basal end it gives off a large branch, from a calcareous internode, which forms the main part of the colony. The nodes are 5 to $6 \mathrm{~mm}$. long, fluted and rough on surface. The branchlets are mostly broken off on one side, and on the opposite side there are 4 branches, one of which gives off lateral twigs. One of these twigs is forked distally. The other fragments show some anastomoses.

The calyces are lateral, sometimes opposite, and often subopposite. They are about $2 \mathrm{~mm}$. apart from summit to summit, conical in shape, a typical one being $1.3 \mathrm{~mm}$. high and $2 \mathrm{~mm}$. broad at base. The calyx walls are covered with a mosaic-like pavement of polygonal or irregular spicules, and similar ones cover the cœnenchyma. The specimens are covered with erect, minute, needle-like sponge spicules, as 
described by Wright and Studer. The polyps are entirely retracted, the calyx walls meeting at the point of the cone. The tentacles are destitute of spicules. There are often two large ova or planulæ in the basal part of the calycular cavity.

Spicules: These are rather irregular disks than spindles, with an oval outline, and coarsely tuberculate throughout. Sometimes they are thickly branched and have an irregular outline.

Color: The colony is light yellow or creamy-white. The internodes are brownish.

Localities.-Station 4893; Ose Saki Light, N. $29^{\circ}$ E., 5.5 miles; 106-95 fathoms. Station 4894; Ose Saki Light, N. $41^{\circ}$ E., 5 miles; 95 fathoms. Station 4895; Ose Saki Light, N. $42^{\circ}$ E., 4.7 miles; 95 fathoms. Station 4935; Sata Misaki Light, N. 58 ${ }^{\circ}$ E., 4.5 miles; 103 fathoms. Station 4936; Sata Misaki Light, N. $21^{\circ}$ E., 5.7 miles; 103 fathoms.

General distribution.-Type-locality, Sulu Sea; ?Mauritius (Ridley); off Kei Islands, 103 fathoms (Wright and Studer).

Family GORGONIDA.

Colony branched, usually flabellate; axis usually horny, not jointed; calyces lateral; spicules usually in the form of spindles; stem and branches often flattened.

\section{Genus PLATYCAULUS Wright and Studer.}

Axis with a calcareous center; calyces prominent; spicules spiny spindles and stellate forms.

\section{PLATYCAULUS DANIELSSENI Wright and Studer.}

Platycaulus danielsseni Wright and Studer, Challenger Reports, the Alcyonaria, 1889, p. 147.

Colony roughly flabellate, profusely branched; the branches, but not the axis, flattened. The axis does not show the calcareous center described by Wright and Studer.

Length $19.5 \mathrm{~cm}$., spread about $18 \mathrm{~cm}$. The stem and proximal parts of main branches are not flattened, although the lateral position of the calyces gives the appearance of a flattening of the branches. The stem is $4.5 \mathrm{~mm}$. in diameter and forks $1.8 \mathrm{~cm}$. from its base. One of the resultant branches is irregularly branched, approaching a pinnate manner of branching, giving off two short simple branchlets and two compound branchlets on one side and three simple branchlets on the other. The other main branch is very profuse and complex in its branching, some of its branchlets being turned down and bound together by parasitic ophiurans. The branches are all lateral and mainly pinnate in their branchings, the side branchlets being lateral and irregular but usually given off at right angles. Branchings of the 
fourth order produced. There are many parasitic ophiurans and anemones on the colony. The calyces are usually lateral in position, but there are a few on the front of some of the ultimate twigs. They vary greatly in their relative position and in the distance between them. The distal branches are distinctly flattened; but the axis is round and very slender, the flattened appearance of the branches being due to the thickening of the cœenenchma between the lateral calyces.

The calyces are in the shape of domes or short tubes according to the state of contraction of the polyps. Their walls are filled with small spindles and stellate forms, and the region near the margin bears a number of dark red, comparatively heavy, bar-like forms transversely placed. These are continued over the bases of the tentacles and the tentacles themselves, being here longitudinal in position and packing the whole dorsal surfaces of the infolded tentacles.

The cœnenchyma contains very numerous terete spindles with regular whorls of tubercles and also double crosses, crosses, and minute stellate forms packed in several layers.

A cross section of the stem shows a series of well-marked nutrient canals such as are seen in the Plexauridæ, to which this genus is closely allied.

Besides the spicules already described, there are numerous clubshaped forms.

The specimen is exceedingly friable, and fell to pieces in handling. It had been preserved in formalin, and it is barely possible that this had dissolved the calcareous portion of the axis.

Color: The colony is dark red. The spicules are red by reflected light, the bar-like forms being darker, almost crimson and yellowish by transmitted light, which may account for the "amber color" of the original description.

Locality.-The label for this specimen is lost.

Type-locality.-Banda, East Indies.

Genus LEPTOGORGIA Milne Edwards and Haime (emended by Verrill).

Colony flabellate and reticulate; branches flattened and grooved by the water-vascular canals; spicules minute double spindles.

LEPTOGORGIA BERINGI, new species.

Plate 16, figs. $1,1 a$; plate 21, fig. 5 .

Colony flabellate, much branched, $7.9 \mathrm{~cm}$. high and $7.2 \mathrm{~cm}$. broad, base missing. The stem is $2 \mathrm{~mm}$. in diameter, very slightly flattened. The axis is entirely horny. The stem branches $1.8 \mathrm{~cm}$. from its base into four main branches, three of which are large, subequal and irregularly branched, producing branchings of the fifth order. The fourth 
main branch is anterior and gives off a number of lateral branchlets which are unequally distributed, being from 4 to $25 \mathrm{~mm}$. apart. The calyces are very prominent and are mainly lateral but often anterior in position; but the back of the colony is bare. The calyces average about $2 \mathrm{~mm}$. apart.

The individual calyces are tubular in form. A typical one measures $2.5 \mathrm{~mm}$. to the top of the infolded tentacles, and $1.3 \mathrm{~mm}$. in diameter. Its walls are filled with small fusiform spindles, closely packed, with no definite arrangement. Toward the margin there is a tendency to form eight broad shallow longitudinal folds, extending upward over the bases of the tentacles and forming a thick crest on their dorsal surfaces and eight lobes to the calyx margin. The distal parts of the tentacles are completely hidden and bear few if any spicules.

The spicules are very small short terete spindles, densely tuberculate, the tubercles forming regular whorls around the body of the spicule. Sometimes there is a girdle without tubercles around the center, forming double spindles or double heads.

The cœnenchyma of the stem and branches is packed with similar spindles, usually longitudinal in position.

Color: The colony is very light yellowish, almost cream color. The axis is dark brown proximally, lightening distally.

Locality.-Station 4780 ; lat. $52^{\circ} 01^{\prime}$ N.; long. $174^{\circ} 39^{\prime}$ E.; 1,046 fathoms.

Type-specimen.-Cat. No. 30044, U.S.N.M.

This species seems to be a Leptogorgia according to the definition given by Verrill, but has longer and more prominent calyces than any other species of the genus of which I can find description.

\section{Genus CALLISTEPHANUS Wright and Studer.}

Colony feebly branched; axis horny and calcareous; calyces domeshaped; cœnenchyma thick; spicules spiny spindles, clubs and halfsided warty clubs.

CALLISTEPHANUS PACIFICUS, new species.

Plate 14, figs. 2, $2 a$; plate 21, fig. 6 .

Colony flabellate in form, $7.3 \mathrm{~cm}$. high and $6.4 \mathrm{~cm}$. broad, diameter of stem $1.8 \mathrm{~mm}$. ; $1.4 \mathrm{~cm}$. above its base the main stem produces two opposite branches, projecting at right angles, but afterwards bent upward. One of these is unbranched and the other bears three branchlets on one side; $1.1 \mathrm{~cm}$. above these the stem bends suddenly, giving off from its convex side another branch; $4 \mathrm{~mm}$. above this it bears a large branch, then an opposite pair and a simple branch on one side. The distance between branches varies from 4 to $11 \mathrm{~mm}$. 
The calyces are lateral, sometimes alternate and sometimes opposite, and about 3 to $4 \mathrm{~mm}$. apart from summit to summit.

The axis effervesces slightly in acid, but has no definite calcareous center.

The individual calyces are conical in shape, sometimes tubular. A typical one measures $1.2 \mathrm{~mm}$. in height and $2.2 \mathrm{~mm}$. in diameter. The calyx walls are filled with irregularly placed small spindles, giving a granular appearance. The polyps are retractile, but often rest with the collaret on the calyx margin, and the tentacles are held in a vertical position, except their tips, making a subcylindrical mass with 8 corrugations. The collaret consists of several rows of rather small warty spindles. The tentacles are armed with numerous similar spindles arranged en chevron basally and in several longitudinal rows distally.

The conenchyma of stem and branches is filled with spicules similar to those in the calyx walls, with occasional stout, blunt-ended, bar-like forms irregularly placed.

Spicules: These are exceedingly varied in form. There are regular warty spindles, small double spindles, radiate forms, clubs, etc., besides the very peculiar bar-like forms mentioned above. These are thicker and denser than the others, and more deeply colored, being an intense crimson while the others are nearer brick red or scarlet, $3 \mathrm{~mm}$. long.

Color: The colony is light crimson in color, axis dark brown.

Locality.-Station 4781 ; lat. $52^{\circ} 14^{\prime} 30^{\prime \prime}$ N.; long. $174^{\circ} 13^{\prime}$ E.; 482 fathoms.

\section{Type-specimen.-Cat. No. 30024, U.S.N.M.}

This species, although bearing a very close resemblance to Callistephanus koreni Wright and Studer, differs materially in its spicules, particularly in the bar-like forms which are quite abundant and characteristic. Geographical considerations render it unlikely that the two are identical.

\section{Family GORGONELLID王.}

Axis consisting of a homogeneous calcareous structure or of a calcareous core, not jointed, often fluted by the impressions of the watervascular canals. Spicules usually girdled forms such as double heads, stars, and double clubs.

\section{Genus SCIRPEARELLA Wright and Studer.}

Gorgonellidæ which are simple or branched, not reticulate; calyces in spirals or oblique rows in adult specimens, lateral in young colonies, rather prominent; cœnenchyma rather thick, with spiny spindles and double heads. 


\section{SCIRPEARELLA GRACILIS Wright and Studer.}

Scirpearella gracilis WRIGHT and STUDER, Challenger Reports, the Alcyonaria, 1889, p. 156.

Colony incomplete, unbranched. Axis stony, round, $1.9 \mathrm{~mm}$. in diameter. The specimen is $29 \mathrm{~cm}$. long, with a basal diameter of 3 $\mathrm{mm}$. and a distal diameter of $2 \mathrm{~mm}$.

The calyces are in four rows or two pairs of rows, those of each row of a pair alternating with those of the other row of that pair. Individual calyces low conical verrucæ with the point inclined toward distal end of the colony, $0.9 \mathrm{~mm}$. in diameter at base and $1 \mathrm{~mm}$. high. The walls are filled with minute spicules most of which are warty double heads. The polyps are retractile, and the dorsal surface of the tentacles is packed with small well tuberculated spindles longitudinally arranged.

The spicules are all small, most of them being densely tuberculate double heads or spiny spindles with a distinct depression around the middle. There are also a number of small crosses and a very few minute ordinary spindles.

Color: The colony is very light grayish with a pinkish tinge.

Locality.-Station 4893; Ose Saki Light, N. $29^{\circ}$ E., 5.5 miles; 106-95 fathoms.

General distribution.-The type-locality is off the New Hebrides, 130 fathoms. The species is also widely distributed in the Indian Ocean, Dutch East Indies, etc.

\section{SCIRPEARELLA RUBRA Wright and Studer.}

Scirpearella rubra Wright and STUDER, Challenger Reports, the Alcyonaria, 1889, p. 107.

A single fragment $13.2 \mathrm{~cm}$. long was secured. The calyces are more nearly tubular than in the last species, nearly $2 \mathrm{~mm}$. high and $1.8 \mathrm{~mm}$. wide at base. The margin shows 8 shallow lobes or corrugations. The spicules are much as in the last species, but the girdle around their middle is less conspicuous and often obliterated. A few of the polyps are much larger than the others, sometimes measuring $2.5 \mathrm{~mm}$. high and $3.7 \mathrm{~mm}$. in diameter at the base. On one of these being opened the body cavity was seen to be fllled with an oval mass whose nature was not ascertained.

Locality.-Station 4893; Ose Saki Light, N. $29^{\circ}$ E., 5.5 miles; 106-95 fathoms.

General distribution.-The type-locality is on the Hyalonema Grounds, off Japan, 345 fathoms. It is also found in the Dutch East Indies (Nutting).

\section{Suborder SCLERAXONIA.}

Gorgonacea with an axis cylinder composed of calcareous spicules, fused or free, immersed in a more or less fleshy matrix. 


\section{Family BRIAREID \#.}

Scleraxonia with a pseudo-axis composed of closely packed spicules which are not fused.

\section{Genus PARAGORGIA.}

Colony upright, branched; axis with large water-vascular canals; siphonozooids present.

\section{PARAGORGIA NODOSA Koren and Danielssen.}

Paragorgia nodosa Koren and DAnIeLssen, Nye Gorgonider og Pennatulider tilhorende Norges Fauna, 1883, p. 18.

Colony consisting of a thick stem with short, simple clavate branches, $17 \mathrm{~cm}$. long, $9 \mathrm{~mm}$. in diameter at base. The stem is strongly arched throughout so that its distal end points downward, perhaps on account of being forced into a small bottle. The stem gives off a number of branch as from all sides, some of which are mercly irregular nodules seated immediately on the stem, and others are clavate branches. One of these is $3.4 \mathrm{~cm}$. long, $4 \mathrm{~mm}$. in diameter near its base, and $14 \mathrm{~mm}$. across the thickest part of the nodulated, club-shaped distal end. These end swellings are sometimes more like rude nodulated spheras than clavate in form, and at times such spheres are seated directly on the stem without evident pediccls.

Nearly all of the polyps are situated on these nodulated portions. In one case there are about 18 calyces situated on one of these spherical terminations of a branch. The calyces are about $6.5 \mathrm{~mm}$. apart, from opening to opening. Occasionally a polyp is seated on a main stem or branch, where it may be the beginning of a new branch.

The individual calyces are low verrucæ with 8-lobed margins, about $3 \mathrm{~mm}$. in height and $6 \mathrm{~mm}$. in diameter at the base. Small polyps appear in the spaces between the larger ones. The polyps are completely retractile, and in retraction the tip of the infolded tentacles are far below the calyx margin, the latter itself being involuted during the complete retraction of the polyp. The tentacles bear longitudinal spindles.

The zooids are minute, and their external openings so tightly closed in alcoholic material as to be invisible. On dissection they can be seen in considerable numbers just beneath the surface. They appear to have but a single mesentery.

A. cross section of a branch shows the undifferentiated axis to be composed almost entirely of an aggregation of small spindles traversed by large and conspicuous longitudinal canals of the watervascular system.

Spicules: These are mostly rather small irregular tuberculate spindles, and a few irregular minute double-heads, crosses, etc. The spicules in the pseudo-axis are mostly white in color. 
Color: The colony is a light red, tending toward a salmon color. The polyps are yellow, with red spicules.

Locality.-Station 4772 ; lat. $54^{\circ} 30^{\prime} 30^{\prime \prime} \mathrm{N}$.; long. $179^{\circ} 14^{\prime} \mathrm{E}$.; 344-372 fathoms.

General distribution.-The type was from Norwegian waters, 300 fathoms.

PARAGORGIA REGALIS, new species.

Plate 15 , figs. $1,1 a$; plate 21 , fig. 7 .

Two large specimens of this superb species were secured, but they are so friable that it is impossible to remove them without much breakage from the narrow-necked jar in which they were preserved. The largest specimen is about $30 \mathrm{~cm}$. in height, rudely flabellate in form. The main stem is round and about $1.2 \mathrm{~cm}$. in diameter. The axis is composed mainly of closely packed spindles and is traversed by numerous water-vascular canals.

There are two lateral stubs of branches on the lower part of the main stem. Above these the stem forks, and at the base of one of the resultant branches a small furcate branch is given off. Each of the main branches gives off several small laterals, and these again fork, and this mode of branching continues until the ultimate branches are produced. All of the branches and twigs are round, nodulated in places and terminate in rounded knobs. A typical end knob is $5.5 \mathrm{~mm}$. in diameter, while the twig supporting it is but $2 \mathrm{~mm}$. across. Branchings up to the eighth order are produced.

The calyces are inserted on three sides of the branches, nodules and terminal swellings, being more thickly implanted on the distal parts of the colony, lacking on stem and larger branches and seldom seen on the backs of the branches except on the terminal swellings.

The individual calyces are almost entirely included, being indicated merely by slight swellings around their openings. The margins are divided into 8 distinct lobes. Young polyps are scattered among the larger ones and are of all sizes up to the maximum. The largest verrucæ are about $2 \mathrm{~mm}$. in diameter, and some of the smallest are hard to discriminate from zooids. The calyx walls are packed with small terete spindles, as is the general surface of the ccenenchyma. The polyps are completely retractile. The upper parts of the polyp bodies are armed with 8 longitudinal bands of smail red spindles, very short and stout and longitudinally arranged. These bands broaden at the tentacle bases and pass on up the dorsal surfaces of the tentacles, where they are usually transversely placed, but may lie in any direction.

The smaller or rudimentary polyps so intergrade with zooids, if the latter are present, that it is hard to determine which is which. Possibly the zooids are lacking altogether. 
Spicules: These are mostly small, rather slender and straight, irregularly tuberculate spindles. There are a few minute double heads, crosses, etc. The spindles are rather larger and more slender, especially those of the axis, than in $P$. nodosa. Those of the axis are usually white or colorless.

Color: The colony is a light, clear, brick-red, which fades to nearly white at the base of the main stem.

Locality.-The type and one other specimen were found at station 5079; Omai Saki Light, N. 29 E., 24 miles; 475-505 fathoms.

Type-specimen.-Cat. No. 30018, U.S.N.M.

This is a very well marked species, with much smaller calyces and less well differentiated zooids than the last. Its size is far beyond the maximum of the type of the genus, $P$. nodosa, and both the nodules and individual calyces are much less prominent.

\section{LITERATURE OITED.}

BaLss, H. Ueber Pennatuliden des München Museums, Sonderabdruck aus dem Zoologischen Anzeiger, vol. 34, Nos. 13-14, June, 1909.

Brundin, A. Alcyonarien aus der Sammlung des zoologischen Museums in Upsala, Bihang til Svenska Vet. Akad. Handlingar, vol. 22, Afd. 4, No.3. Stockholm, 1896.

Danielssen, D. C. Forhandl. Vidensk.-Selsk., Christiania, 1858.

Hubrecht, A. A. On a new Pennatulid from the Japanese Sea, Proc. Zool. Soc., London, 1885.

Jüngersen, H. F. E. The Danish Ingolf Expedition, I, the Pennatulida, 1904.

Kinoshita, K. Primnoidæ von Japan, Journal of the College of Science, Imperial University, Tokyo, Japan, vol. 23, article 12, Tokyo, 1908.

On some Muriceid Corals belonging to the Genera Filigella and Acis, Journal of the College of Science, Imperial University, Tokyo, Japan, vol. 27, article 7, Tokyo, 1909.

KöLliker, A. von. Anatomisch-Systematische Beschreibung der Alcyonaria. Die Pennatuliden, 1872.

- Report on the Pennatulida dredged by H. M. S. Challenger during the years 1873-1876, Challenger Reports, Zoology, vol. 1, pt. 2, 1880.

Koren, J. and Danielssen, D. C. Nyt Magazin for Naturvidenskaberne, vol. 5, 1848.

Kükenthal, W. Alcyonaceen von Ternate, Abhandl, der Senckenb. naturforsch. Gesellschaft, vol. 23, Heft I, 1896.

- Versuch einer Revision der Alcyonarien, II, Die Familie der Nephthyiden, Teil I, Zool. Jahrbücher, Abth. für Syst. Geographie und Biologie der Thiere, vol. 19, 1903.

- (Same publication as above), Teil II, 1905.

- Japanische Alcyonaceen; Beitrage zur Naturgeschichte Ostasiens, Herausgegeben von Dr. F. Doflein. Einleitung von Dr. F. Doflein. München, 1906.

- und GoRzawskY, H. Japanische Gorgoniden (same publication as above), Teil I, Die Familien der Primnoiden, Muriceiden und Acanthogorgiiden. 1908. - Japanische Gorgoniden (same publication as above), Teil II, Die Familien der Plexauriden, Chrysogorgiiden und Melitodiden. 1909.

Diagnosen Neuer Japanischen Gorgoniden. Reise Doflein, 1904 (5). Zool. Anz., vol. 32, Nos. 20-21, 1908. 
Nutring, C. C. Descriptions of the Alcyonaria collected by the U. S. Bureau of Fisheries Steamer Albatross in the Vicinity of the Hawaiian Islands in 1902, Proceedings of the U. S. National Museum, vol. 34, 1908, pp. 543-601.

Alcyonarians of the Californian Coast, Proceedings of the U. S. National Museum, vol. 35, 1909, pp. 681-727.

Gorgonacea of the Siboga Expedition, III, the Muriceidæ. Leiden, 1910.

Pallas, A. S. Elenchus Zoophytorum, 1766.

Studer, TH. Übersicht der Anthozoa Alcyonaria welche während die Reise S.M.S.

Gazelle um die erde gesammelt wurden. Monatsbericht der königl. Akademie der Wissenschaften zu Berlin, 1878.

Thomson, J. A, and Henderson, M. A. Report on the Pearl Fisheries of the Gulf of Manaar, Supplementary Reports, No. XX, The Alcyonaria. London, 1906.

- _ An account of the Alcyonaria collected by the Royal Indian Marine Survey Ship Investigator in the Indian Ocean. I, The Alcyonaria of the Deep Sea. Calcutta, 1906.

- and Simpson. (Same publication as above.) II, The Alcyonaria of the Littoral Zone, Calcutta, 1909.

Verril, A. E. Notice of recent additions to the Marine Fauna of the Eastern coast of North America, No. 2. American Journal of Science and Arts, vol. 16, 1878.

- Report on the Anthozoa and on some Additional Species dredged by the Blake in 1877-1879, and by the U. S. Fish Commission steamer Fish Hawk in 1880. Bulletin of the Museum of Comparative Zoölogy, vol. 11, No. 1; Cambridge, 1883.

- Notice of the Remarkable Marine Fauna occupying the outer banks off the Southern Coast of New England, No.9. American Journal of Science and Arts, ser. 5 , vol. $28,1884$.

Versuuys, J. Die Gorgoniden der Siboga Expedition, I, Die Chrysogorgiidæ. Leiden, 1902.

_- (Same publication as above) II, Die Primnoidæ, Leiden, 1906.

Wright, E. P., and Studer, Th. Report on the Alcyonaria collected by H. M. S. Challenger during the Years 1873-1876, vol. 31, part 64. London, 1889.

\section{EXPLANATION OF PLATES.}

The photographs were made from nature by C. C. Nutting.

The spicules were drawn under the camera lucida by Dayton Stoner.

\section{Plate 1.}

Fig. 1. Clavularia japonica, natural size; $1 a$, single calyx $\times 4.3$.

2. Clavularia sulcata, natural size; $2 a$, single calyx $\times 4.3$.

3. Lithophytum roseum, natural size; $3 a$, portion of colony $\times 4.3$.

Plate 2.

Fig. 1. Dendronephthya nigripes, natural size; $1 a$, part of branch $\times 4.3$.

2. Dendronephthya magnacantha, natural size; $2 a$, part of branch $\times 4.3$.

3. Dendronephthya oviformis, natural size; $3 a$, part of branch $\times 4.3$.

4. Bellonella flava, natural size; $4 a$, part of colony $\times 4.3$.

\section{Plate 3.}

Fig. 1. Alcyonium kükenthali, natural size; 1 a, part of surface $\times 4.3$.

2. Anthomastus japonicus, natural size; $2 a$, zooids on surface $\times 4.3$.

3. Nidalia gracilis, natural size; $3 a$, part of colony $\times 4.3$. 


\section{Plate 4.}

Fig. 1. Pennatula brevipenna, natural size; $1 a$, single leaf $\times 4.3$.

2. Pennatula longistyla, natural size; $2 a$, part of leaf $\times 4.3$.

3. Ptilosarcus brevicaulis, natural size; $3 a$, single leaf $\times 4.3$.

\section{Puate 5.}

Fig. 1. Pennatula rubescens, natural size; $1 a$, single leaf $\times 4.3$.

2. Halisceptrum album, natural size; $2 a$, single leaf $\times 4.3$.

3. Pennatula inermis, single leaf $\times 4.3$.

\section{Plate 6.}

Fig. 1. Protoptilum orientale; $1 a$, end of colony $\times 4.3$.

2. Kophobelemnon hispidum, natural size; $2 a$, single tentacle $\times 4.3$.

3. Umbellula eloisa, natural size; $3 a$, single tentacle $\times 4.3$.

4. Balticina pacifica, part of colony $\times 4.3$.

Plate 7.

Fig. 1. Thouarella recta, natural size; $1 a$, part of branch $\times 4.3$.

2. Helicoptilum rigidum, natural size; $2 a$, part of colony $\times 4.3$.

3. Trichoptilum spinosum, natural size; $3 a$, group of polyps $\times 4.3$.

\section{Plate 8.}

Fig. 1. Plumarella adhærans, natural size; $1 a$, part of branch $\times 4.3$.

2. Plumarella spicata, natural size; $2 a$, part of branch $\times 4.3$.

\section{Plate 9.}

Fig. 1. Thouarella alternata, natural size; $1 a$, part of branch $\times 4.3$.

2. Primnodendron superbum, natural size; $2 a$, part of branch $\times 4.3$.

Plate 10.

Fig. 1. Acanthogorgia fusca, natural size; $1 a$, part of branch $\times 4.3$.

2. Thouarella striata, natural size; $2 a$, part of branch $\times 4.3$.

\section{Plate 11.}

Fig. 1. Muriceides cylindrica, natural size; $1 a$, part of branch $\times 4.3$.

2. Acanthogorgia paradoxa, natural size; $2 a$, part of branch $\times 4.3$.

3. Muricella abnormalis, natural size; $3 a$, part of branch $\times 4.3$.

Plate 12.

Fig. 1. Muriceides nigra, natural size; $1 a$, part of branch $\times 4.3$.

2. Villogorgia brunnea, natural size; $2 a$, part of branch $\times 4.3$.

\section{Plate 13.}

Fig. 1. Placogorgia japonica, natural size; $1 a$, part of branch $\times 4.3$.

2. Acis spinifera, natural size; $2 a$, part of branch $\times 4.3$.

3. Anthomuricea aberrans, natural size; $3 a$, part of branch $\times 4.3$.

Plate 14.

Fig. 1. Muricella reticulata, natural size; $1 a$, part of branch $\times 4.3$.

2. Callistephanus pacificus, natural size; $2 a$, part of branch $\times 4.3$. 


\section{Plate 15.}

Fig. 1. Páragorgia regalis, natural size; $1 a$, part of branch $\times 4.3$.

2. Elasmogorgia ramosa, natural size; $2 a$, part of branch $\times 4.3$.

\section{Puate 16.}

Fig. 1. Leptogorgia beringi, natural size; $1 a$, part of branch $\times 4.3$.

2. Calyptrophora ijimai, natural size.

3. Calyptrophora ijimai, natural size, showing symbiotic annelid and the remarkable structure of metamorphosed spicules created by its presence.

\section{Prate 17.}

Fig. 1. Clavularia sulcata. Four spicules, $a, b, c$, ànd $d, \times 120$.

2. Clavilaria japonica. Four spicules, $a, b, c$, and $d, \times 250$.

3. Lithophytum roseum. Three spicules, $a, b$, and $c, \times 250$.

4. Dendronephthya nigripes. Three spicules, $a, b$, and $c, \times 64 ; b$ is about onehalf total length.

5. Dendronephthya magnacantha. Two spicules, $a$ and $b, \times 64$.

6. Dendronephthya oviformis. Two spicules, $a$ and $b, \times 64$.

\section{Plate 18.}

Fig. 1. Alcyonium kükenthali. Three spicules, $a, b$, and $c, \times 120$.

2. Nidalia gracilis. Three spicules, $a, b$, and $c, \times 250$.

3. Bellonella flava. Five spicules, $a, \times 250 ; b, c, d$, and $e, \times 88$.

4. Anthomastus japonicus. Two spicules, $a$ and $b, \times 250$.

5. Helicoptilum rigidum. Two spicules, $a$ and $b, \times 64$.

6. Plumarella spicata. Three spicules, $a$ and $b, \times 120 ; c, \times 250$.

Plate 19.

Fig. 1. Plumarella adhrerans. Three spicules, $a, b$, and $c, \times 120$.

2. Thouarella recta. Three spicules, $a$ and $b, \times 120 ; c$, circumopercular scale, $\times 120$.

3. Thouarella alternata. Four spicules, $a$, circumopercular scale, $\times 64 ; b, c$, and $d, \times 88$.

4. Primnodendron superbum. Three spicules, $a, b$, and $c, \times 88$.

5. Acanthogorgia fusca. Four spicules, $a, b, c$, and $d, \times 64$.

Plate 20.

Fig. 1. Acanthogorgia paradoxa. Three spicules, $a, b$, and $c, \times 88$.

2. Anthomuricea aberrans. Three spicules, $a, b$, and $c, \times 88$.

3. Muriceides cylindrica. Five spicules, $a, b, c, d$, and $e, \times 64$.

4. Muriceides nigra. Three spicules, $a, b$, and $c ; a$ and $c, \times 88 ; b, \times 64$.

5. Muricella reticulata. Three spicules, $a$ and $b, \times 64 ; c, \times 88$.

6. Muricella abnormalis. Two spicules, $a$ and $b, \times 64$.

Plate 21.

Fig. 1. Acis spinifera. Four spicules, $a, b, c$, and $d, \times 64$.

2. Placogorgia japonica. Three spicules, $a, b$, and $c, \times 88$.

3. Tillogorgia brunnea, Four spicules, $a, b, c$, and $d, \times 120$.

4. Elasmogorgia ramosa. Three spicules, $a, b$, and $c, \times 88$.

5. Leptogorgia beringi. Two spicules, $a$ and $b, \times 250$.

6. Callistephanus pacificus. Six spicules, $a, b, c, d, e$, and $f, \times 120$.

7. Paragorgia regalis. Two spicules, $a$ and $b, \times 88$. 
U. S. NATIONAL MUSEUM

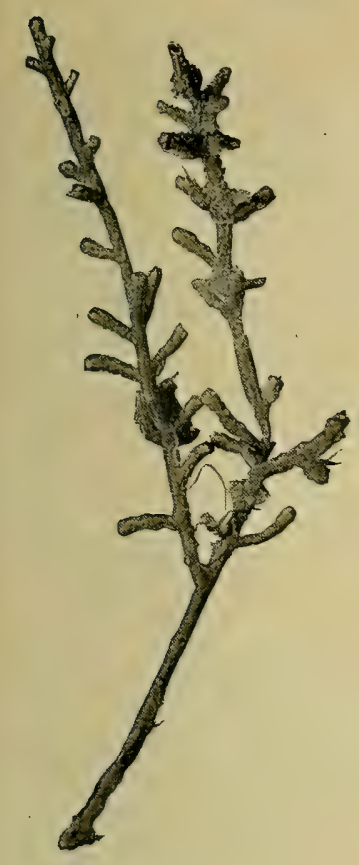

1

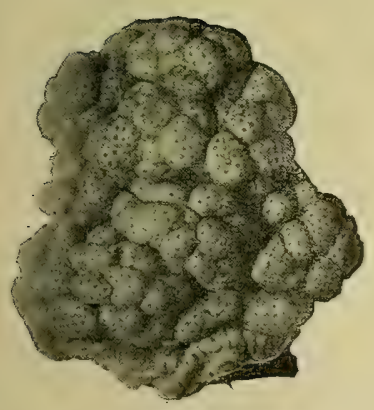

3

PROCEEDINGS, VOL. 43 PL. 1

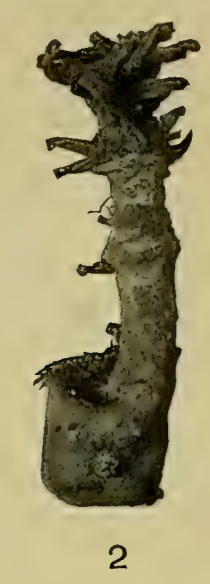

\section{$2 a$}

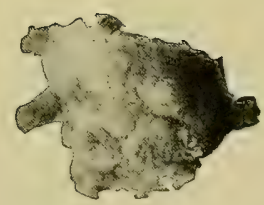

$3 a$
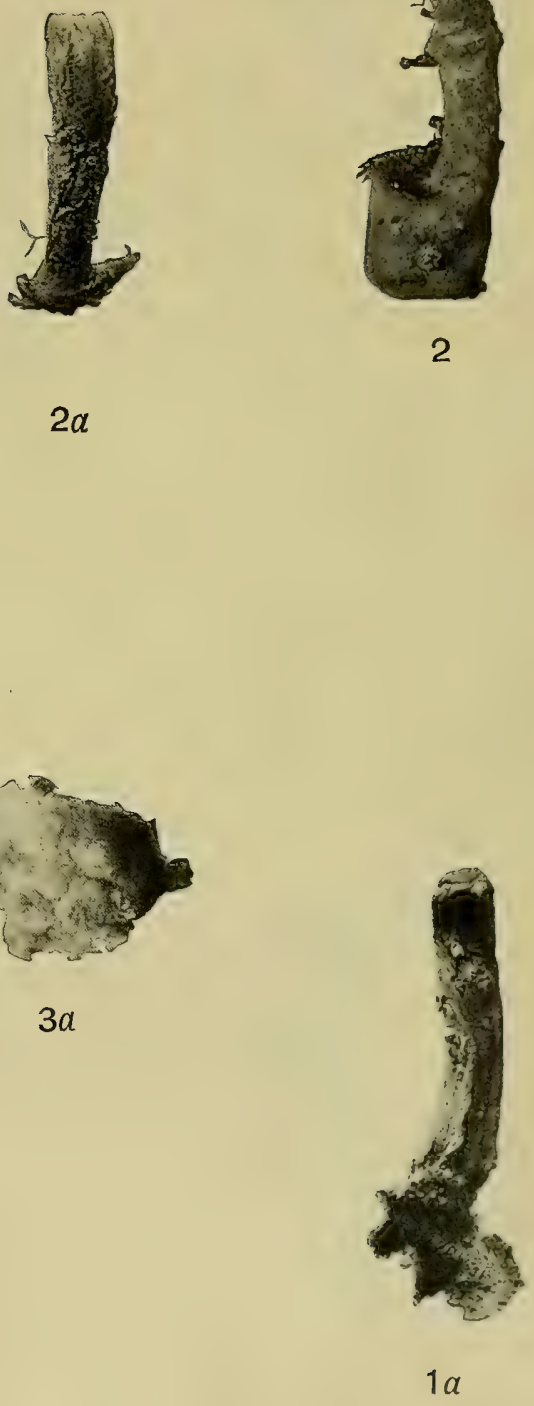

ALCYONARIA FROM THE NORTHWEST PACIFIC OCEAN.

For explanation of PLATE SEe Page 102. 

U. S. NATIONAL MUSEUM

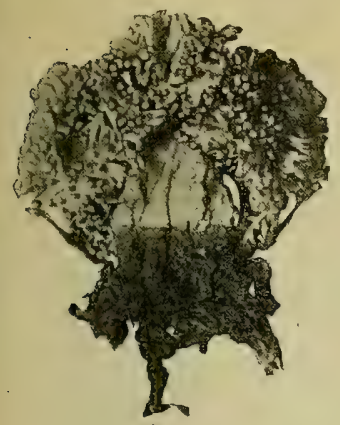

1

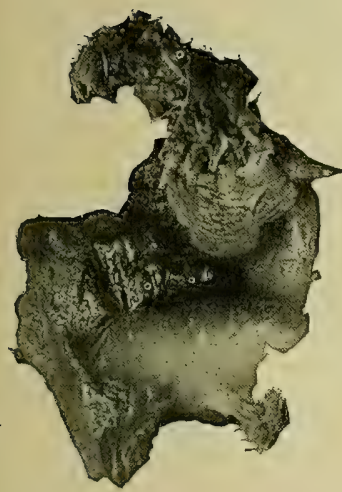

2

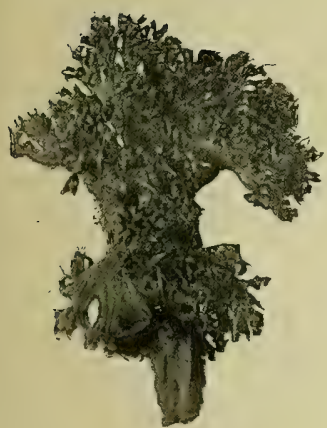

3
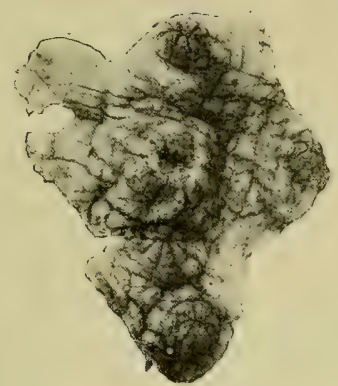

$4 a$
PROCEEDINGS, VOL. 43 PL. 2

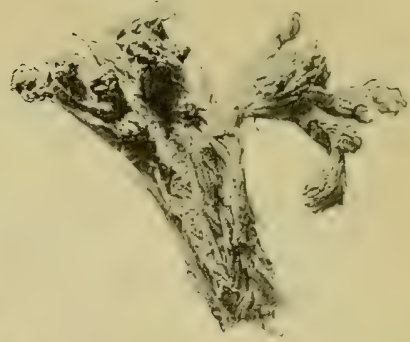

$1 a$
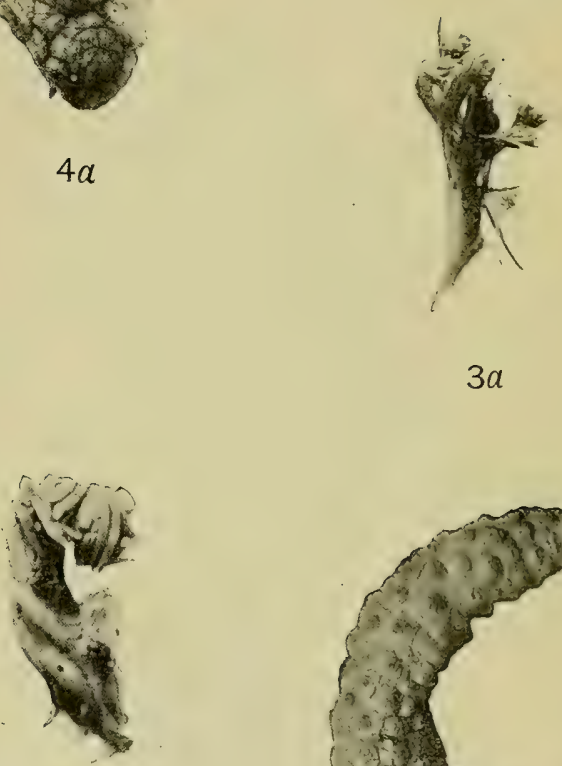

$3 a$

$2 a$

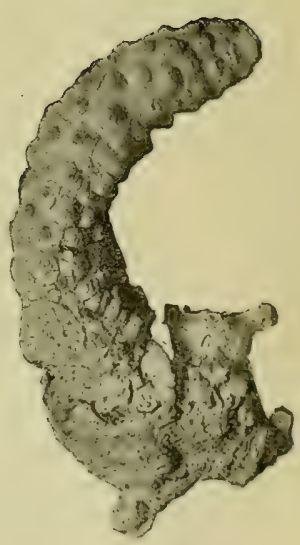

4

ALCYONARIA FROM THE NORTHWEST PACIFIC OCEAN.

FOR EXPLANATION OF PLATE SEE PAGE 102. 

U. S. NATIONAL MUSEUM

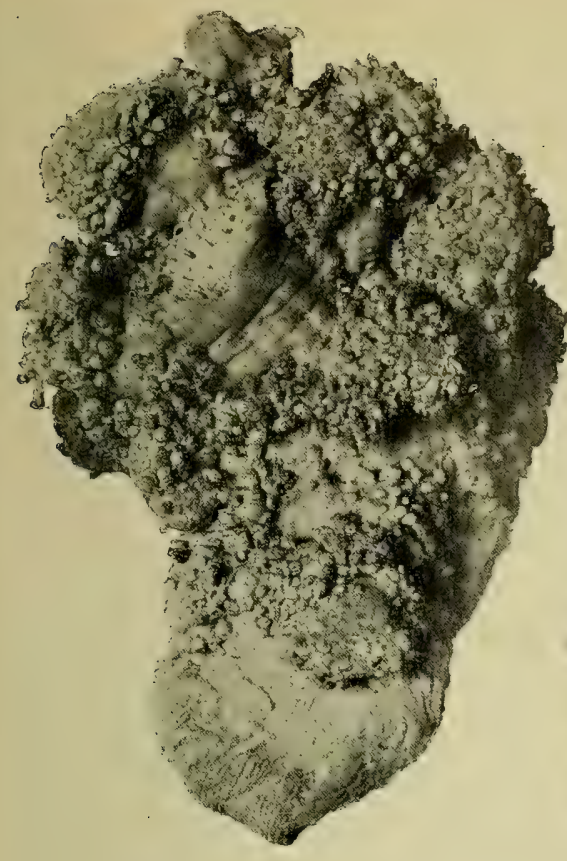

1

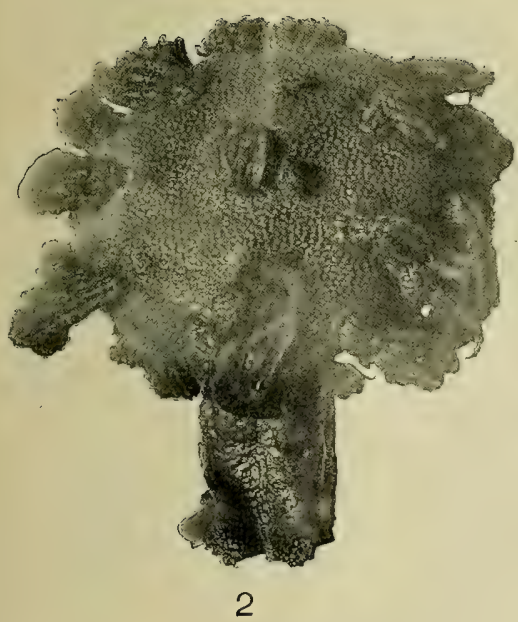

Alcyonaria fRom the NoRTHWEst Pacific Ocean.

FOR EXPLANATION OF PLATE SEE PAGE 102

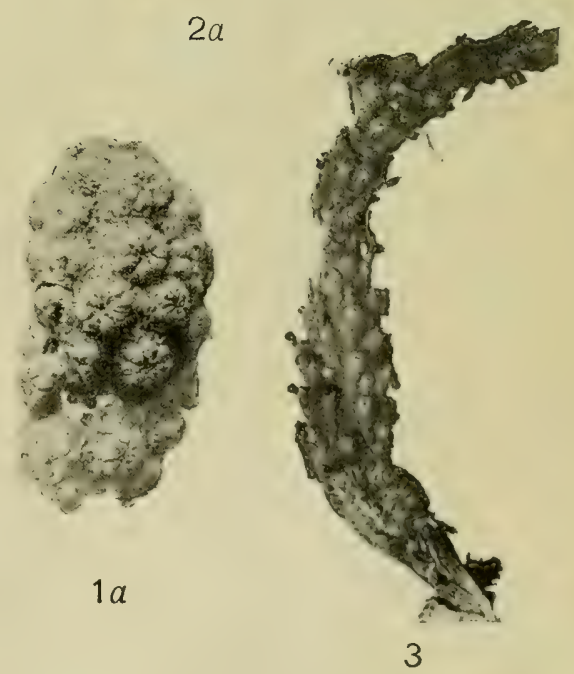

PROCEEDINGS, VOL. $43 \mathrm{PL} 3$

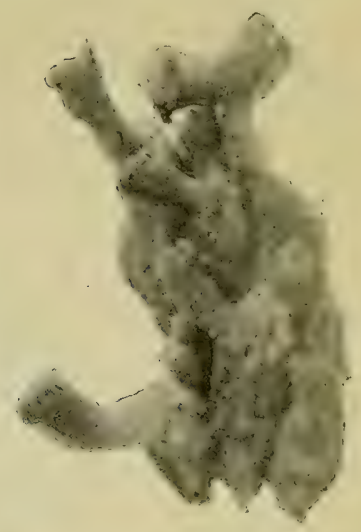

$3 a$ 



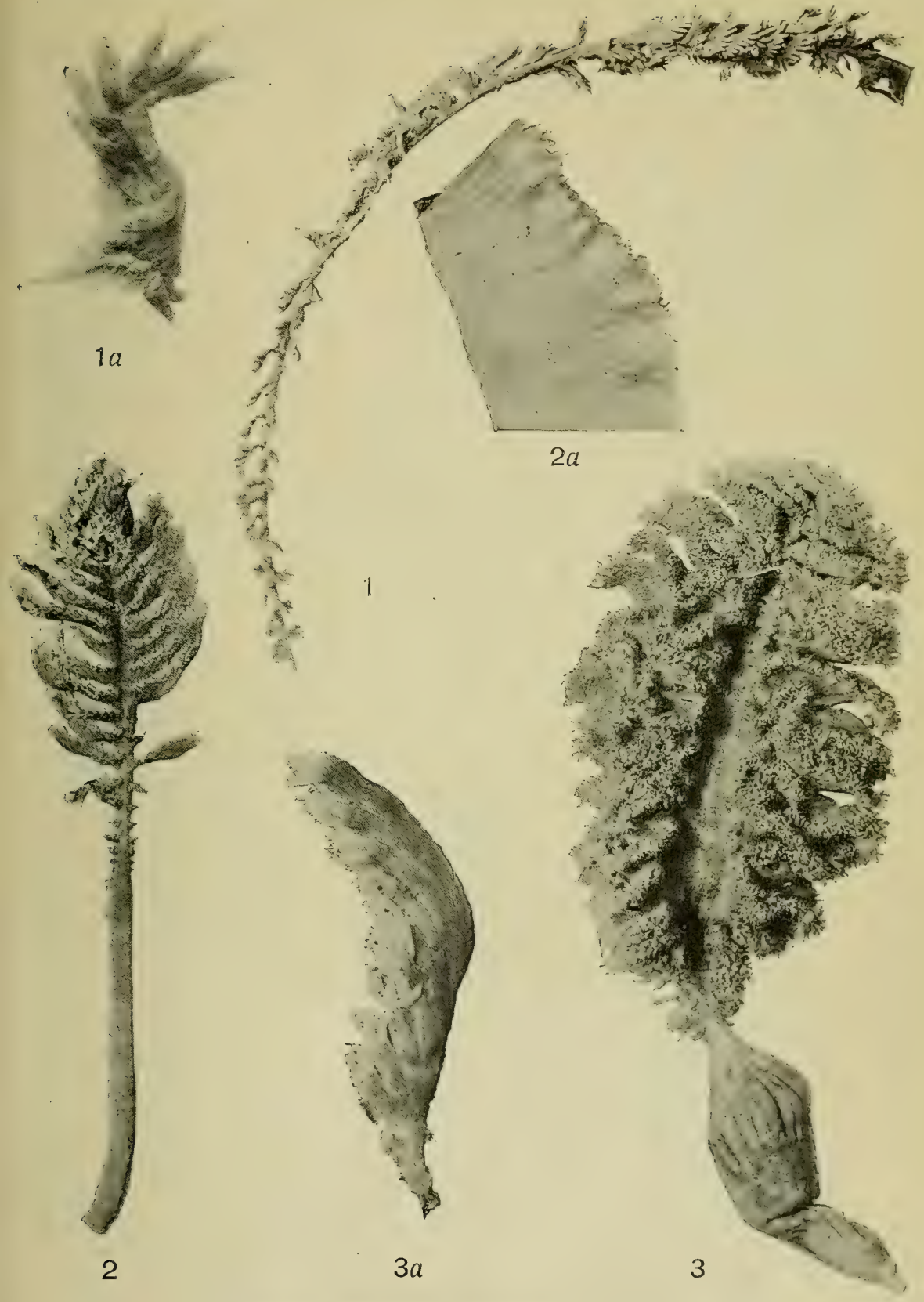

ALCyONARIA FROM THE NORTHWEST PACIFIC OCEAN.

For explanation of plate see page 103. 

U. S. NATIONAL MUSEUM

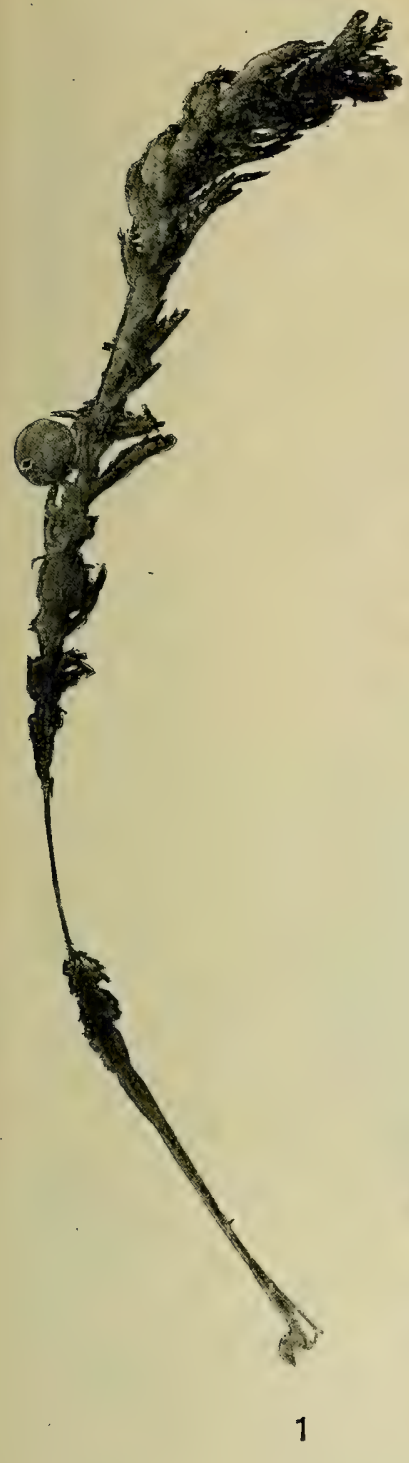

PROCEEDINGS, VOL, 43 PL. 5
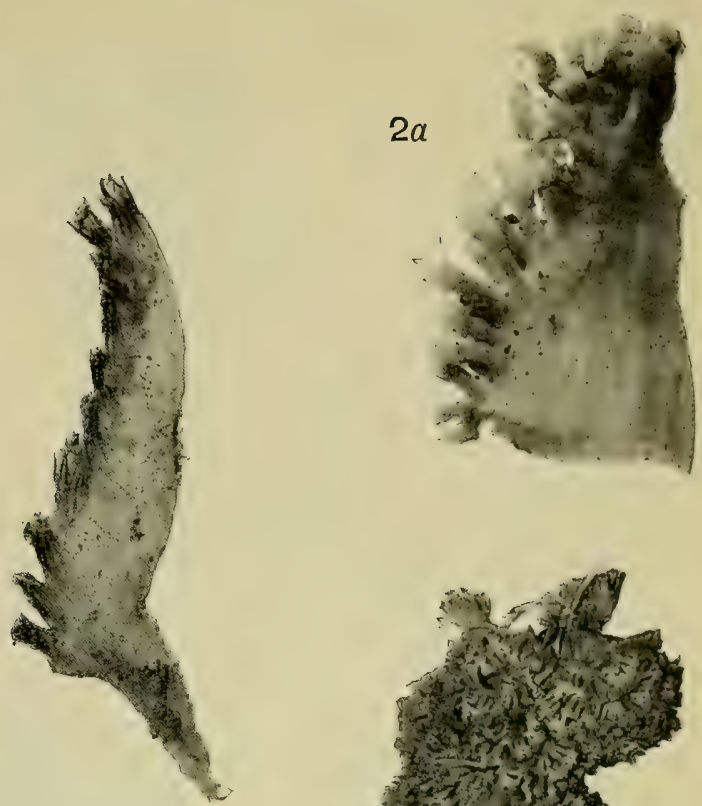

$1 a$

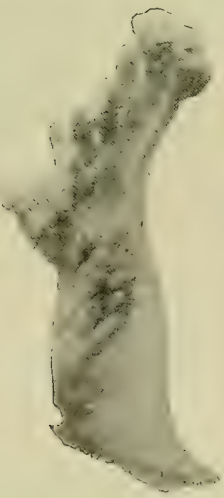

3
2

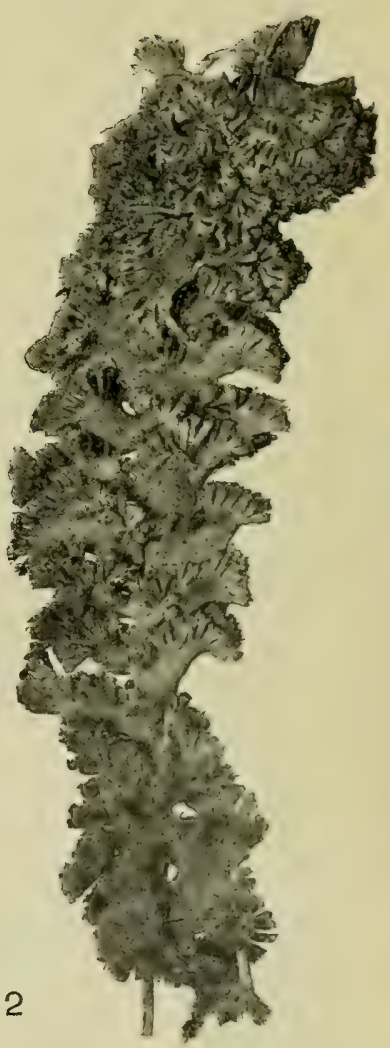

Alcyonaria from the NorthWest Pacific OcEan.

For EXPLANATION OF PLATE SEE PAGE 103. 

U. S. NATIONAL MUSEUM

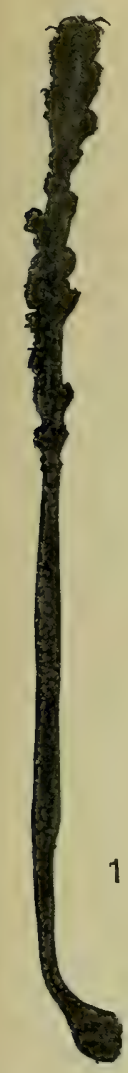

PROCEEDINGS, VOL. 43 PL. 6

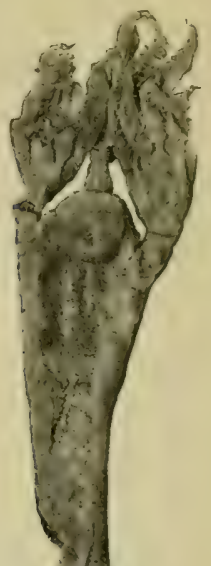

$a$
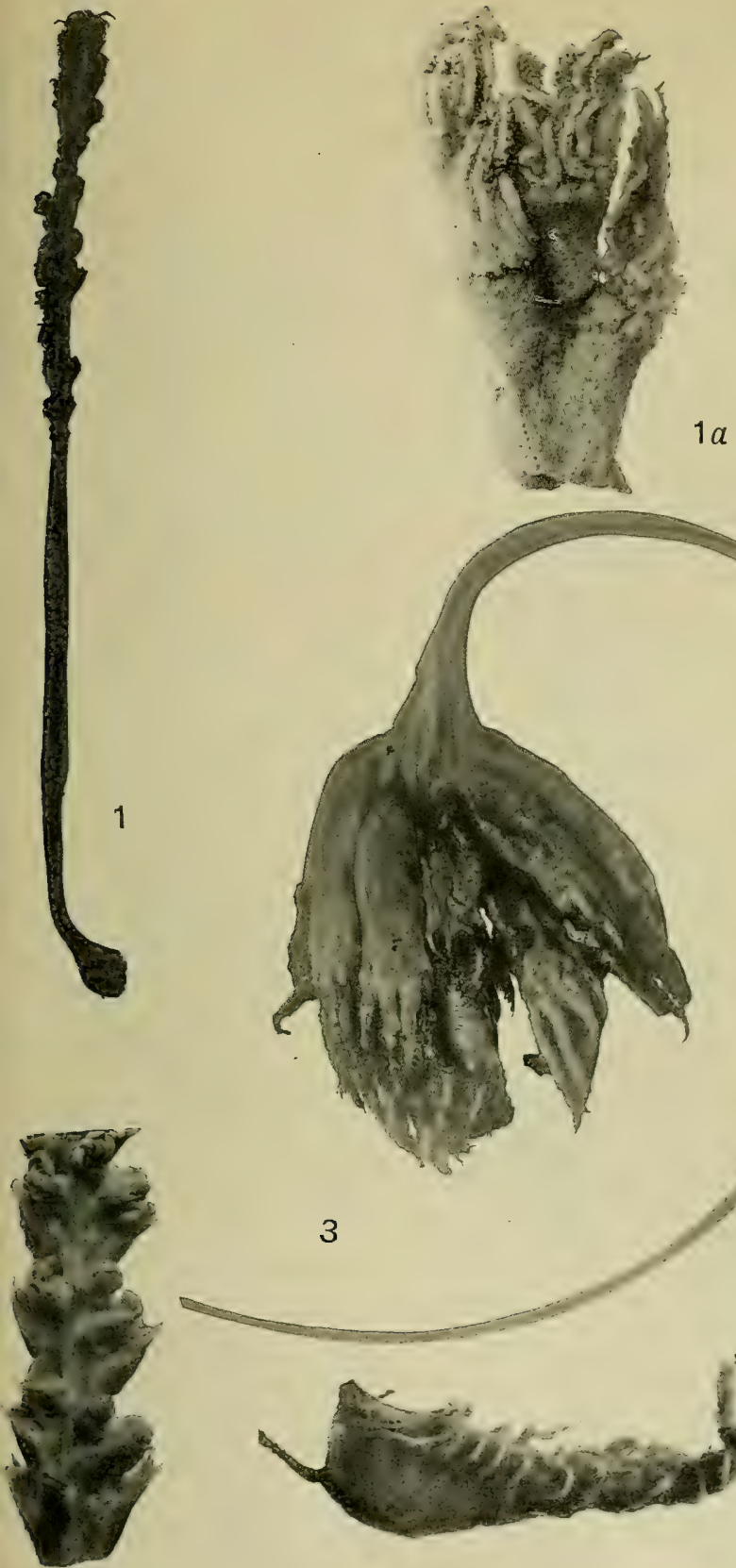

2
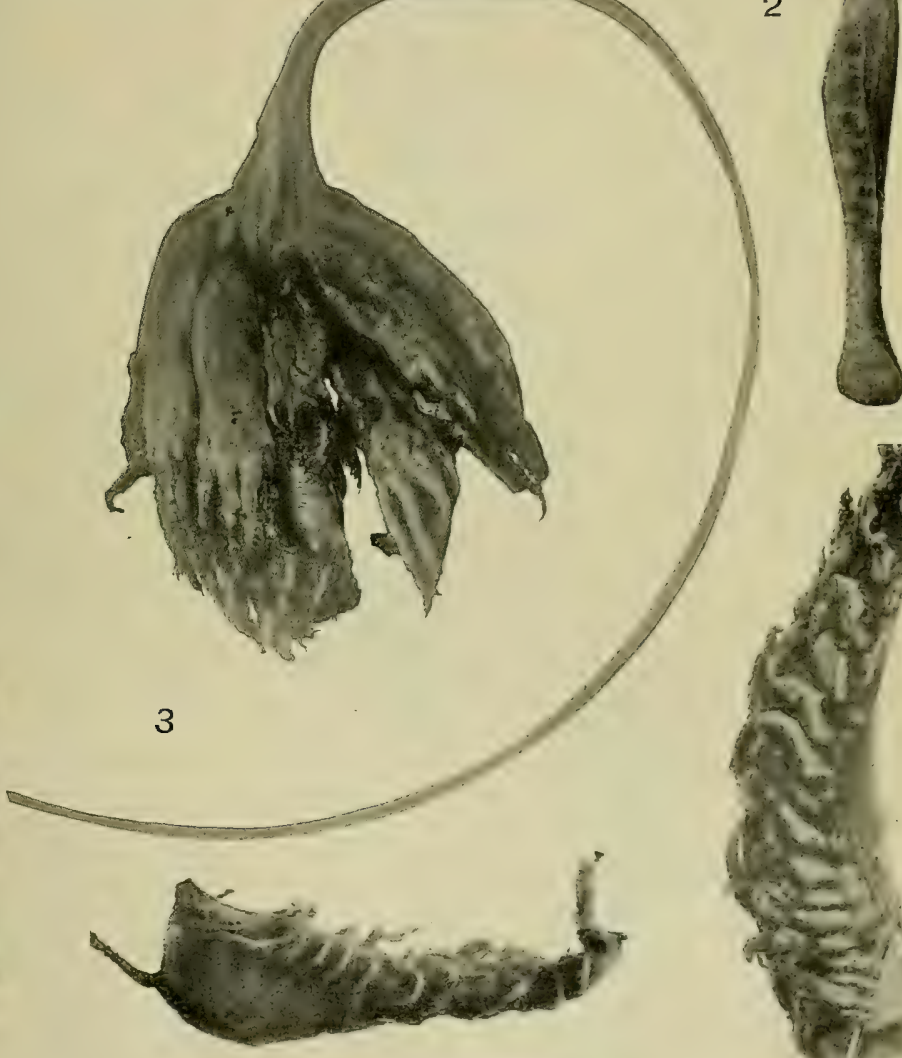

$2 a$

$3 a$

ALCYONARIA FROM THE NORTHWEST PACIFIC OCEAN.

For EXPLANATION Of FLATE SEe PAge 103. 

U. S. NATIONAL MUSEUM

PROCEEDINGS, VOL. 43 PL. 7
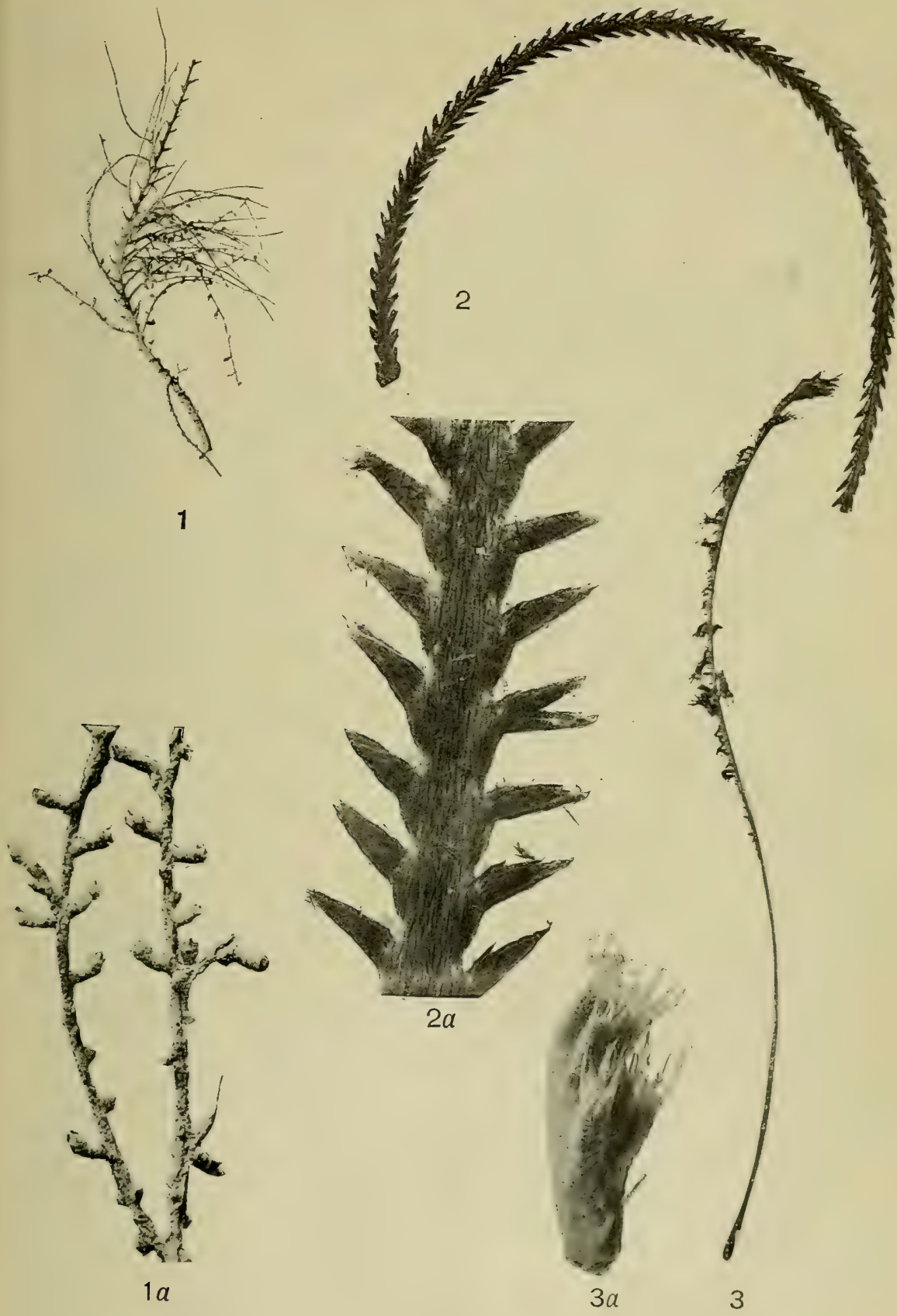

AlCyONARIA FROM the NORTHWEST PACIFIC OCEAN.

For EXPLANATION OF PLATE SEe PAgE 103. 




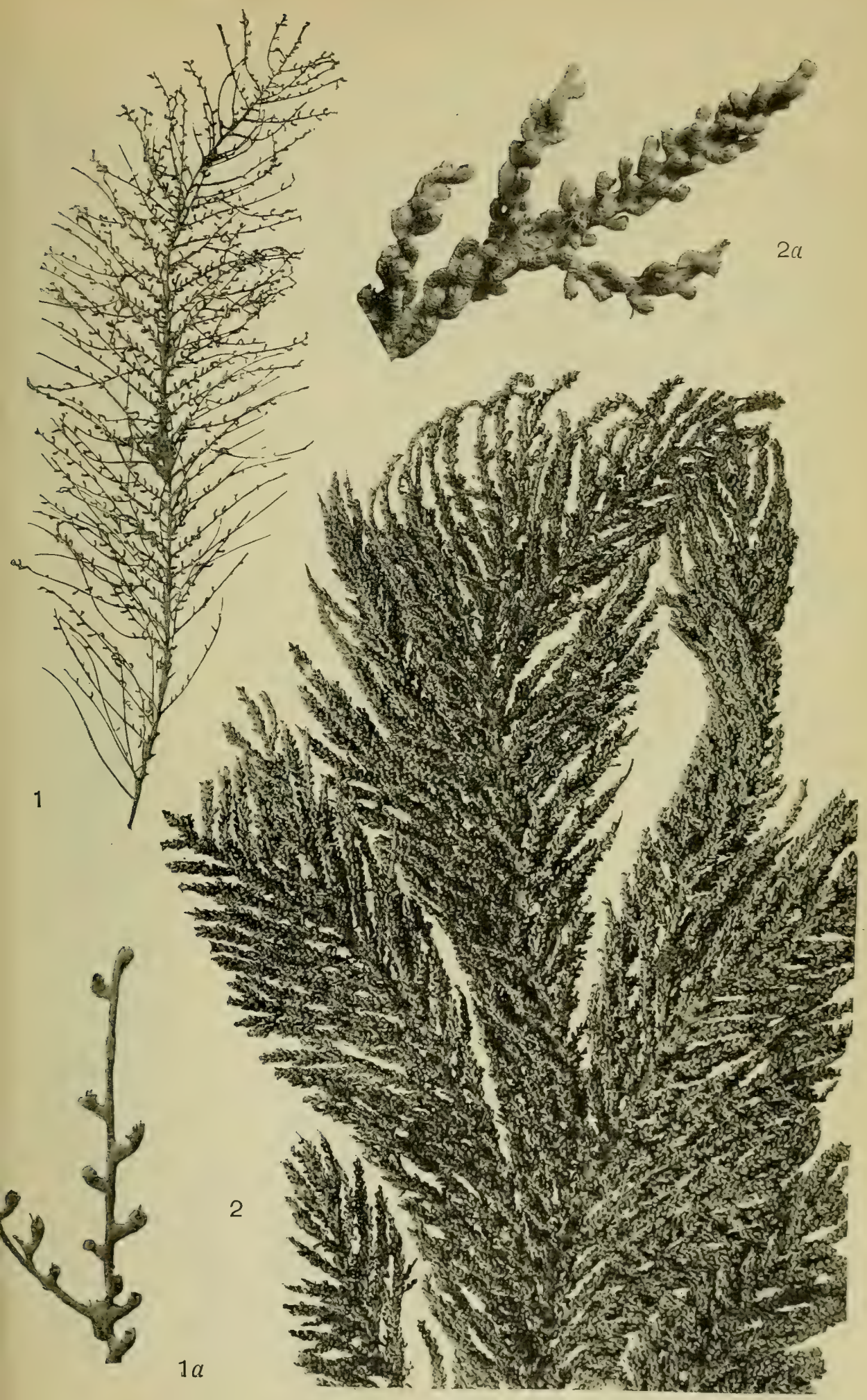





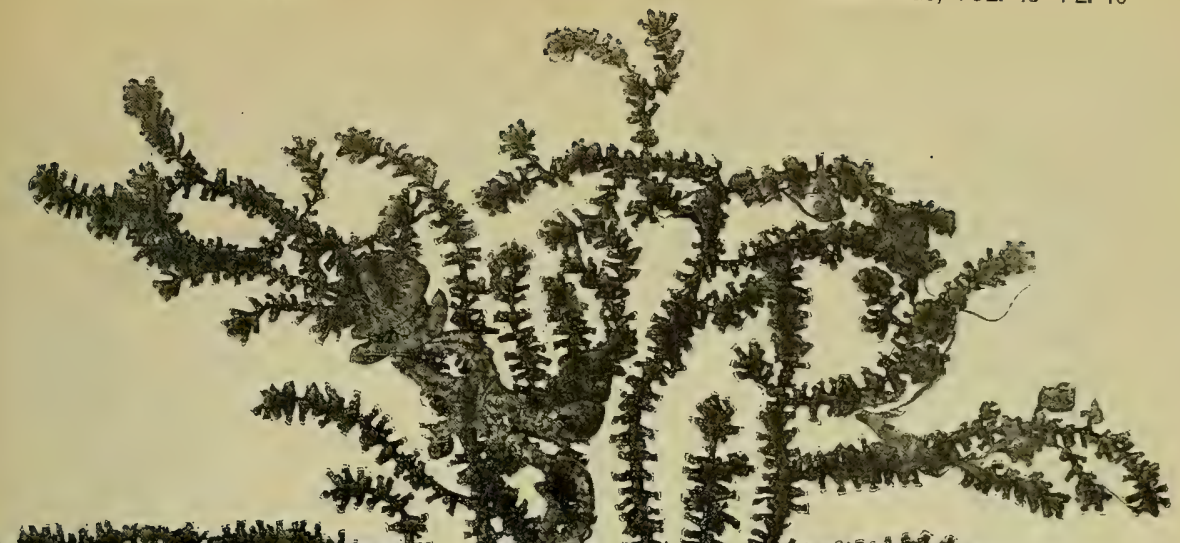

(1)

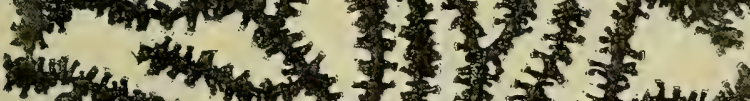

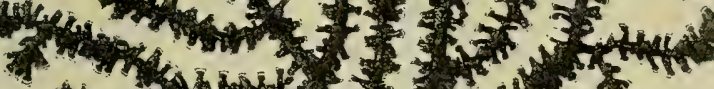

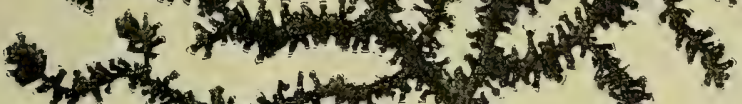

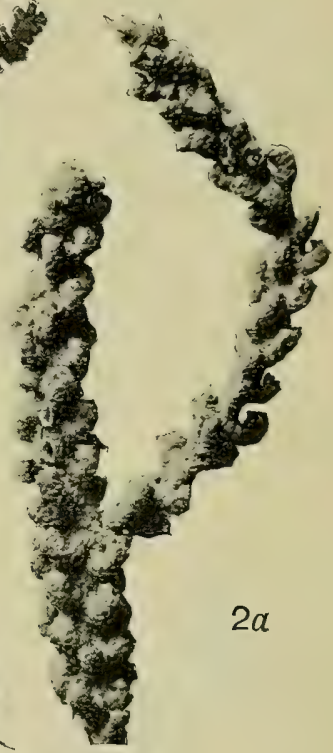

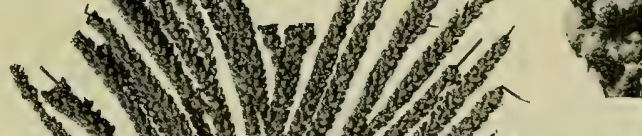
की

the

atose

सink

.

W.

(1)

$x \rightarrow 3$

$28 \sin ^{2}$

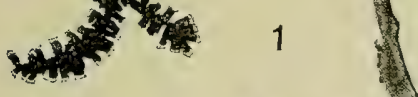

(1)

7.

orito 3

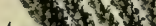

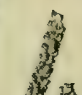

. 3

10

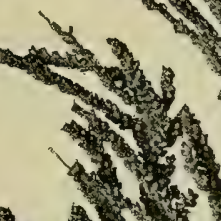

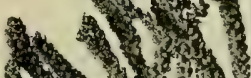
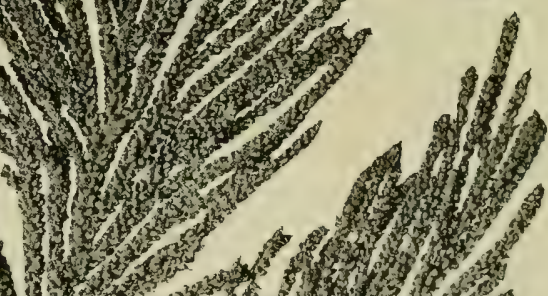

1.7.

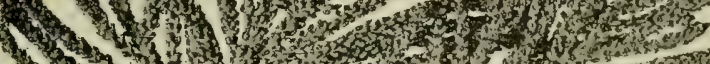

$1 a$

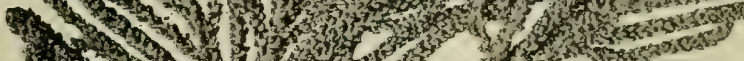

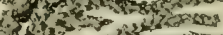

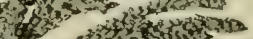

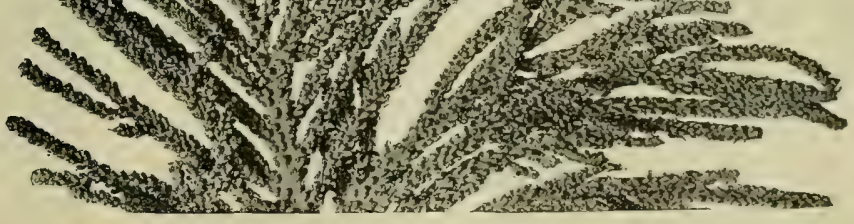





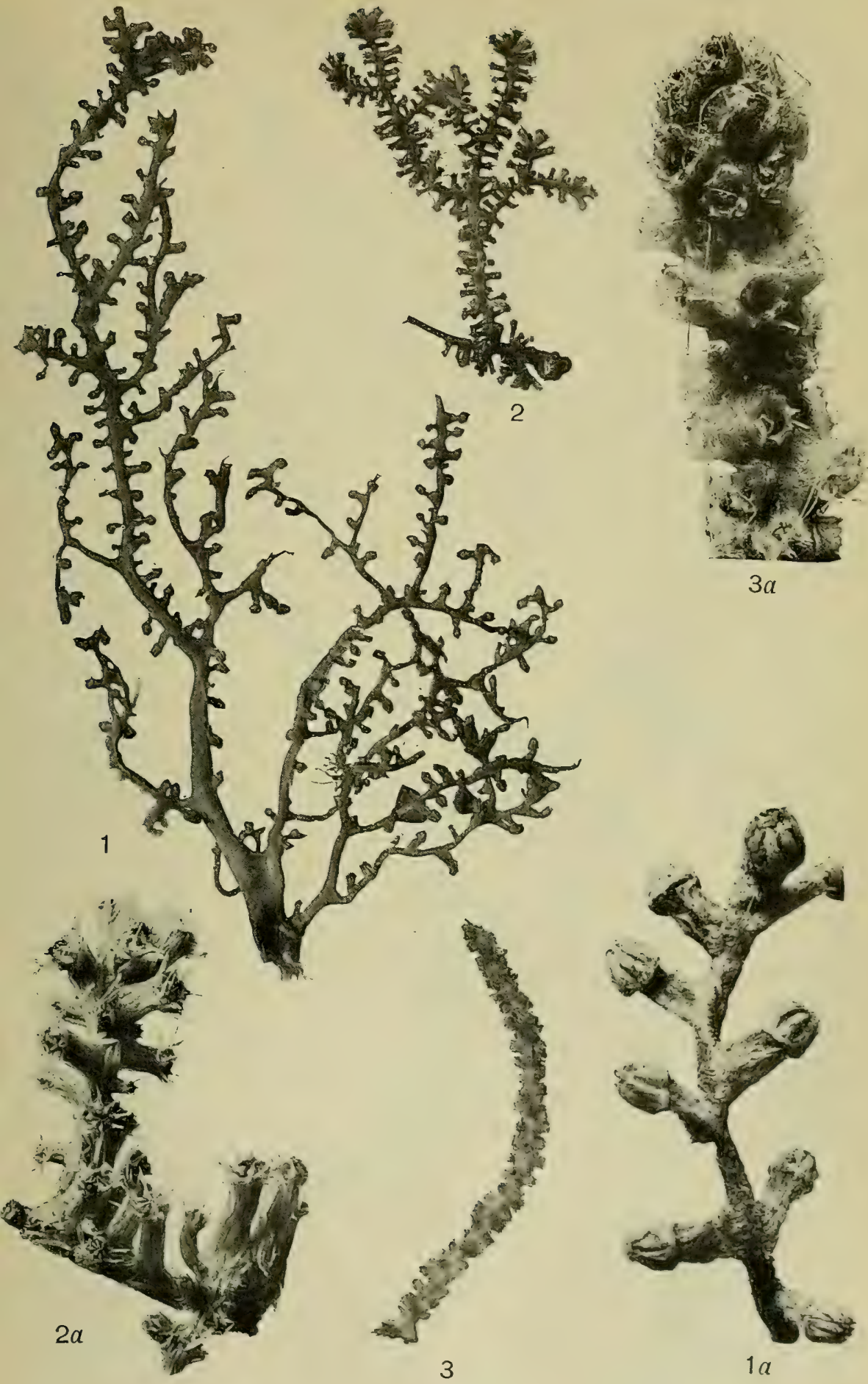

ALCYONARIA FROM THE NORTHWEST PACIFIC OCEAN.

For EXPLANATION OF PLATE SEE PAgE 103. 



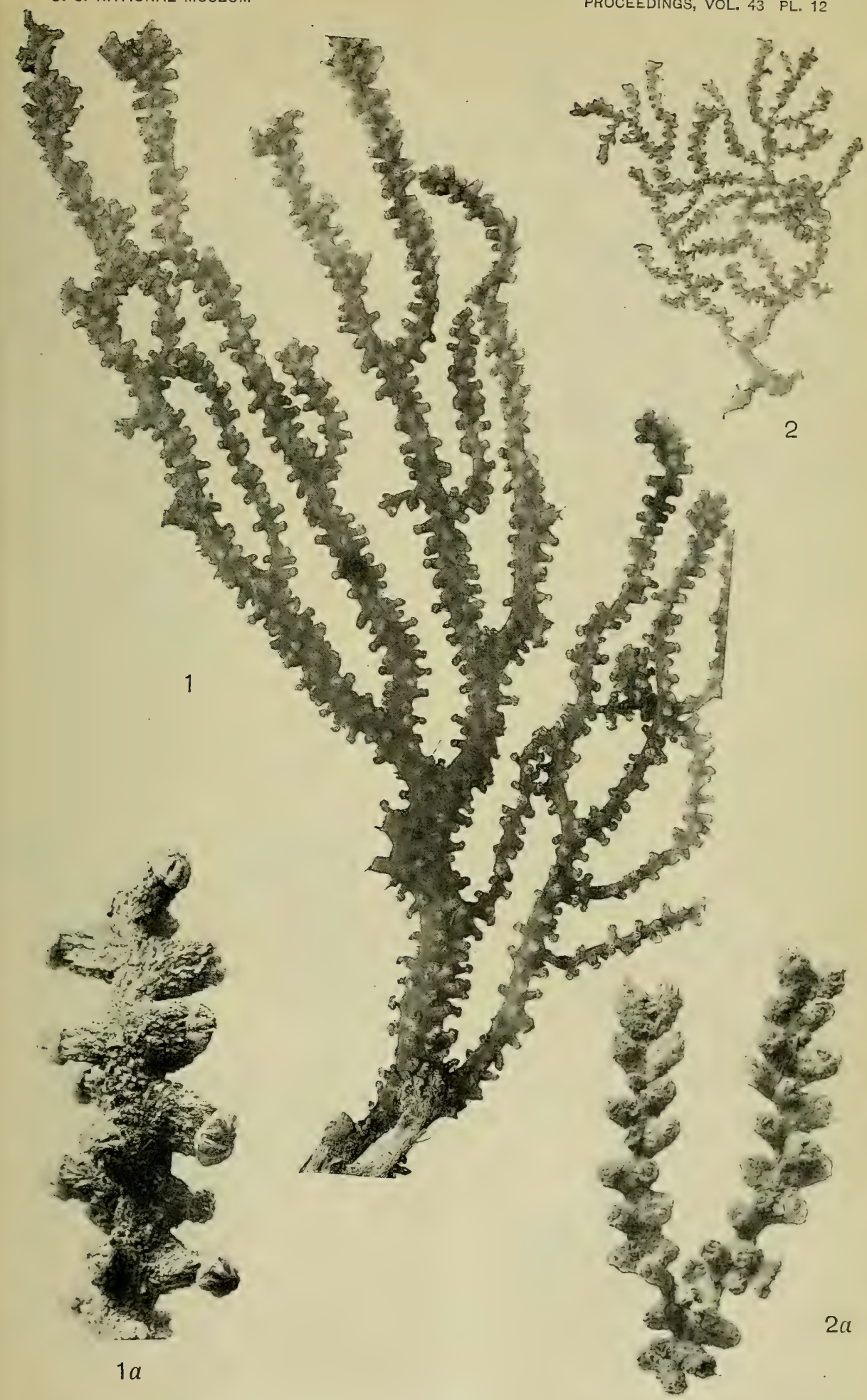

ALCYONARIA FROM THE NORTHWEST PACIFIC OCEAN.

For EXPLANATION OF PLATE SEE PAGE 103. 


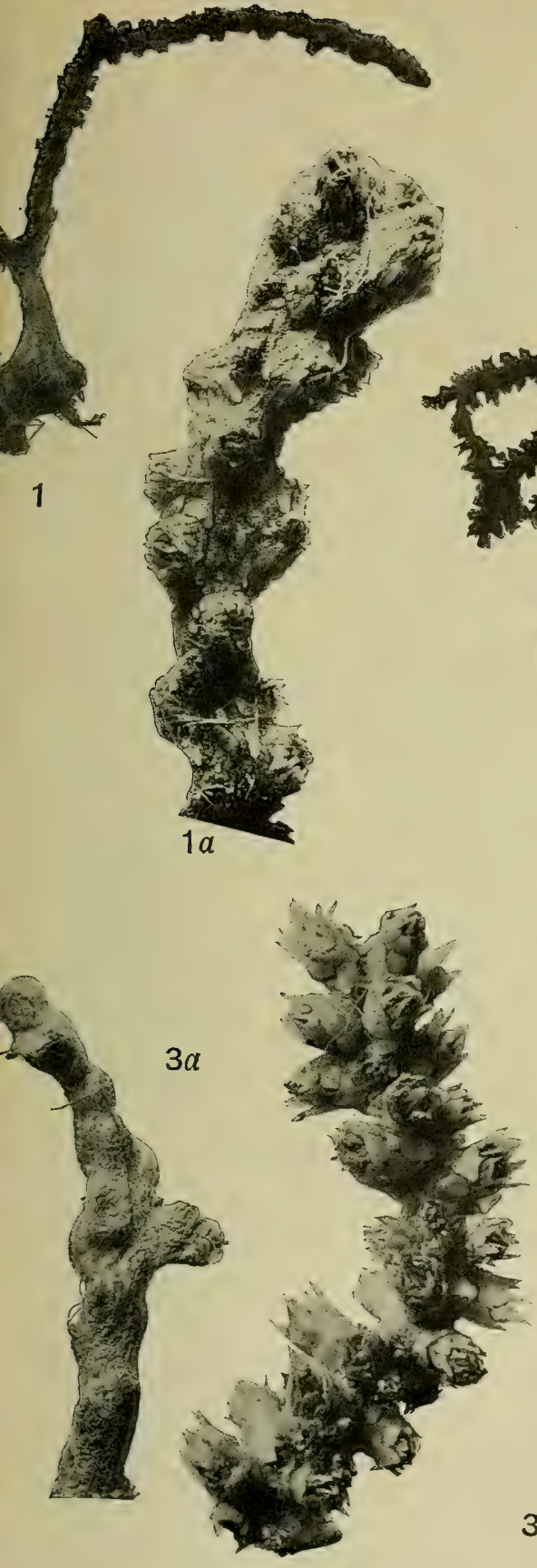

3

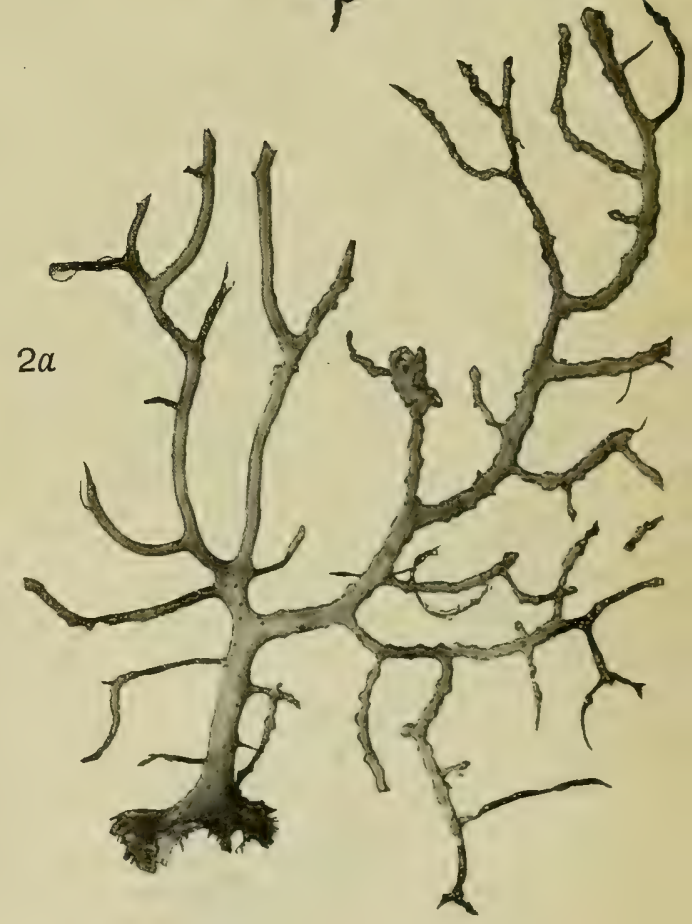

ALCYONARIA FROM THE NORTHWEST PACIFIC OCEAN. 




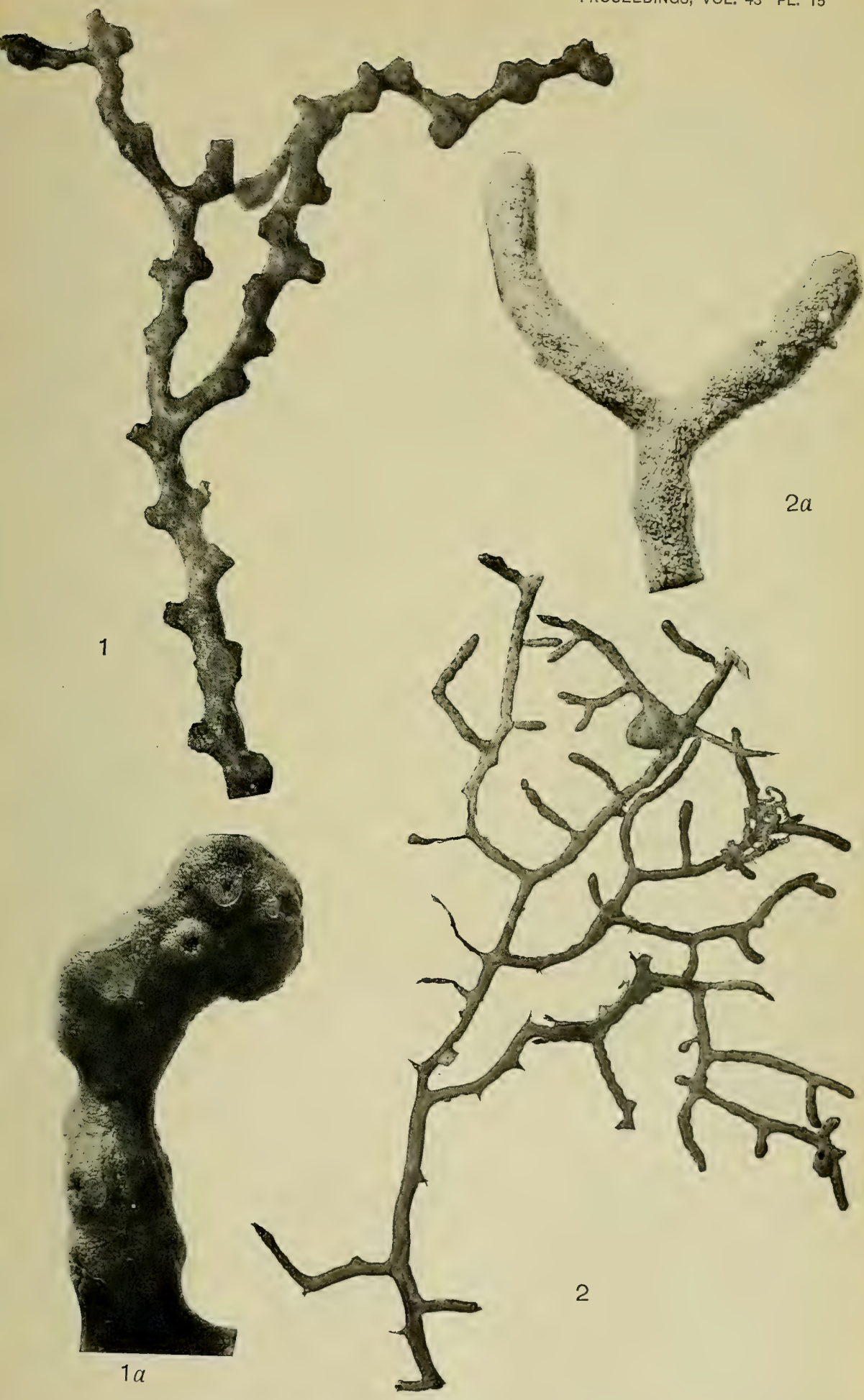

Alcronaria from the Northwest Pacific Ocean.

For EXPLANATION OF PLATE SFE PAGE 104. 


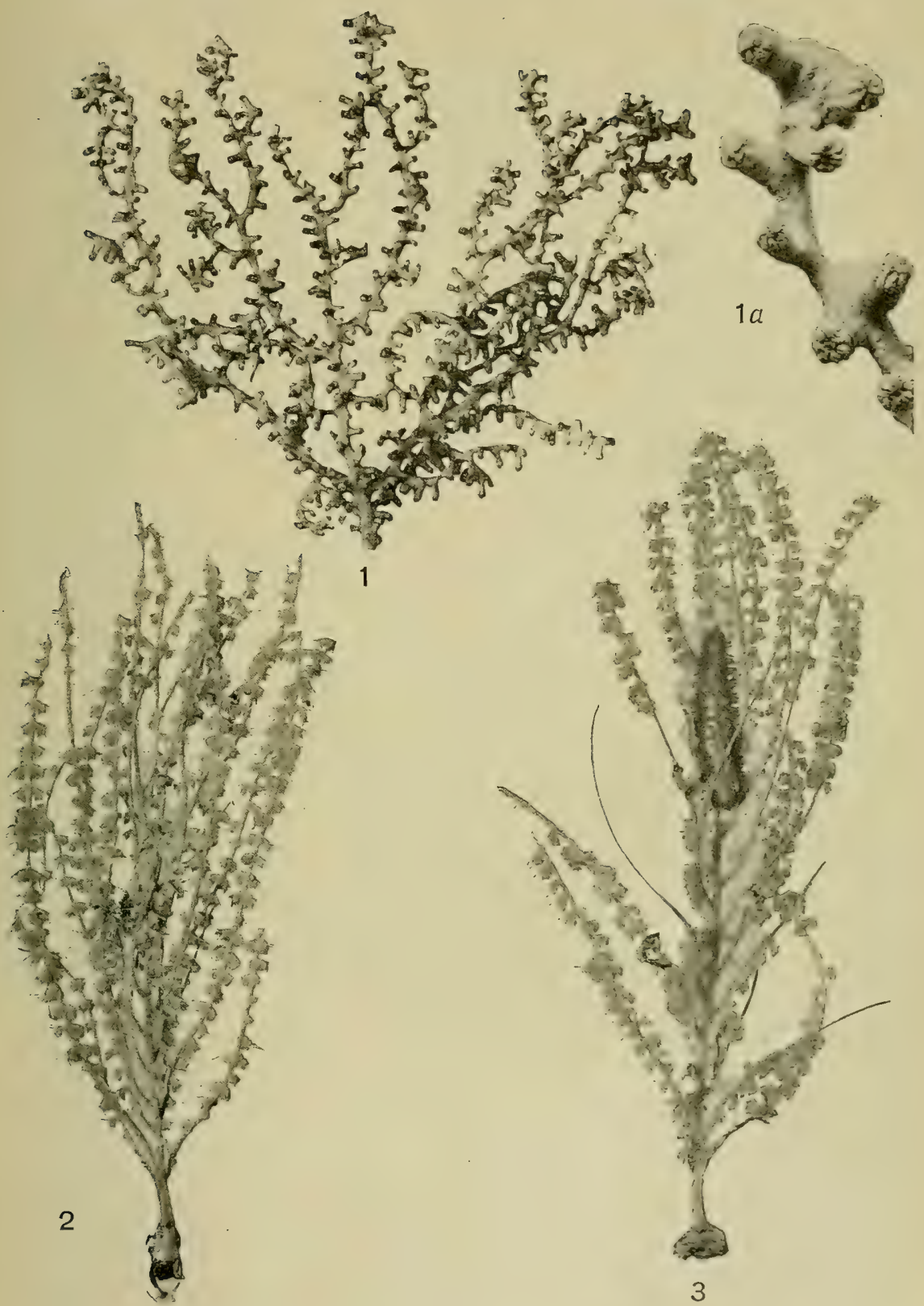

ALCYONARIA FROM THE NORTHWEST PACIFIC OCEAN.

For EXPLANATION OF PLATE SEe PAGE 104. 

U. S. NATIONAL MUSEUM

PROCEEDINGS, VOL. 43 PL. 17
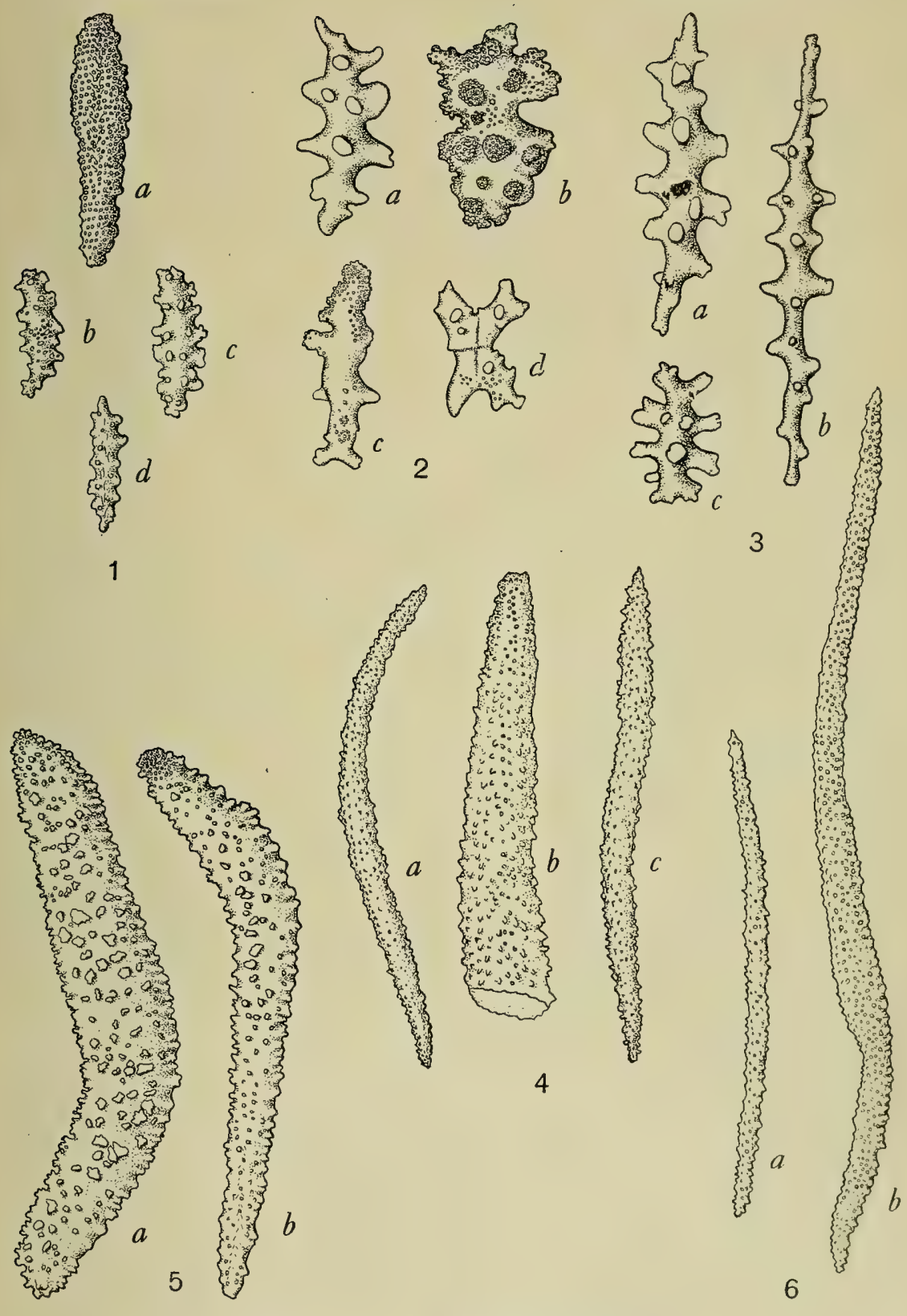

ALCYONARIA FROM THE NORTHWEST PACIFIC OCEAN.

FOR EXPLANATION OF PLATE SEE PAGE 104. 


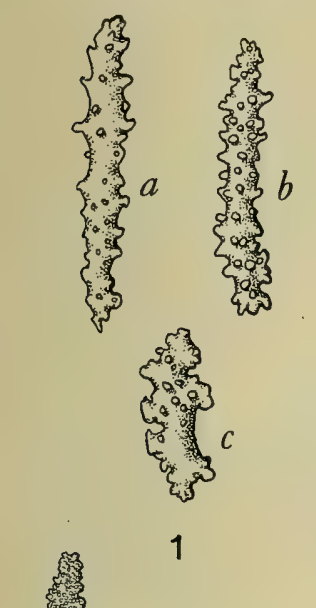

a

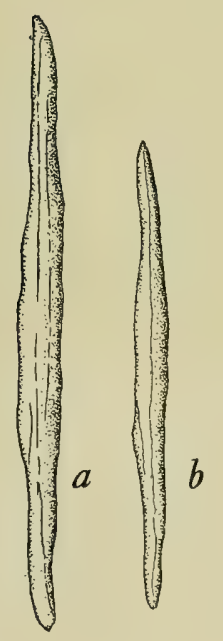

5
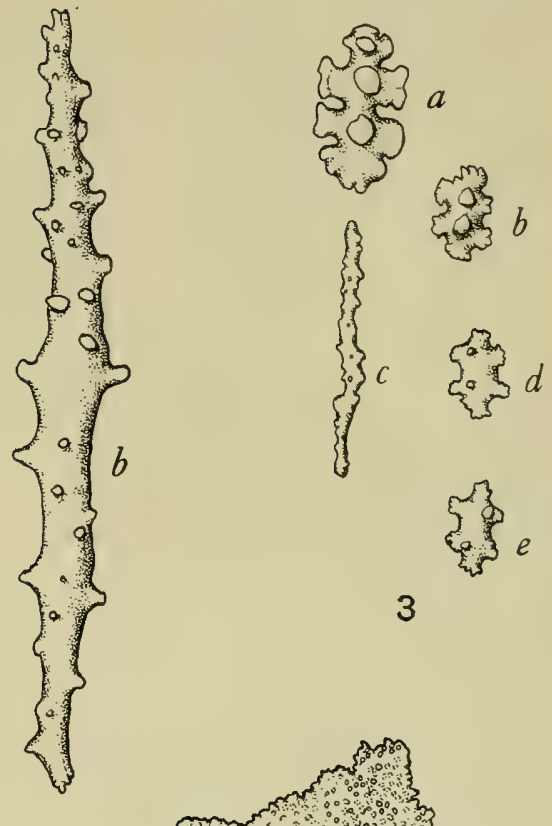

3
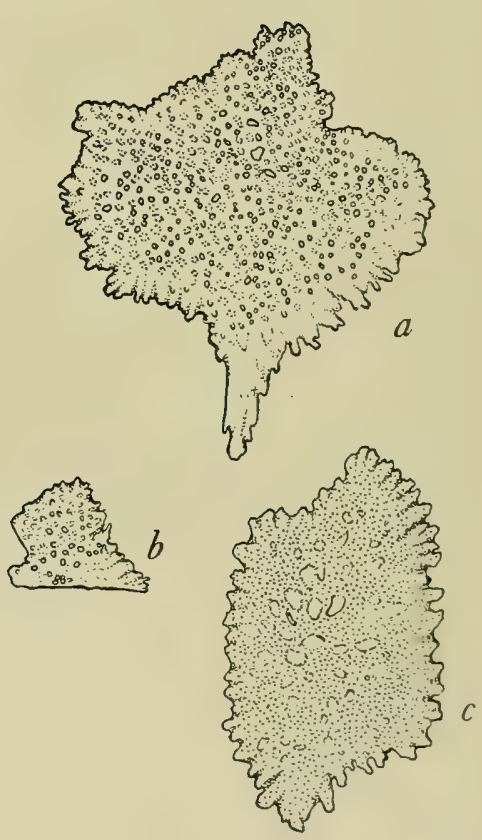

6

ALCYONARIA FROM THE NORTHWEST PACIFIC OCEAN.

FOR EXPLANATION OF PLATE SEE PAGE 104. 

U. S. NATIONAL MUSEUM
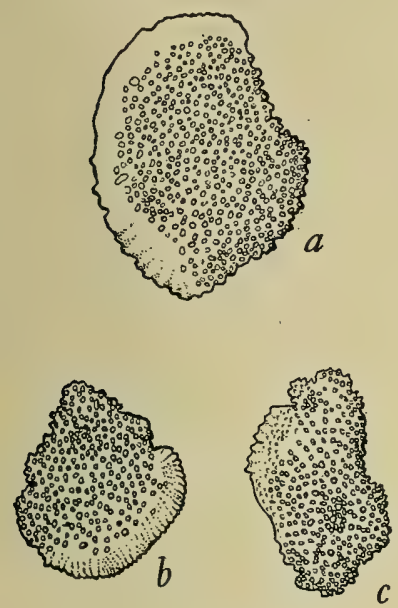

1
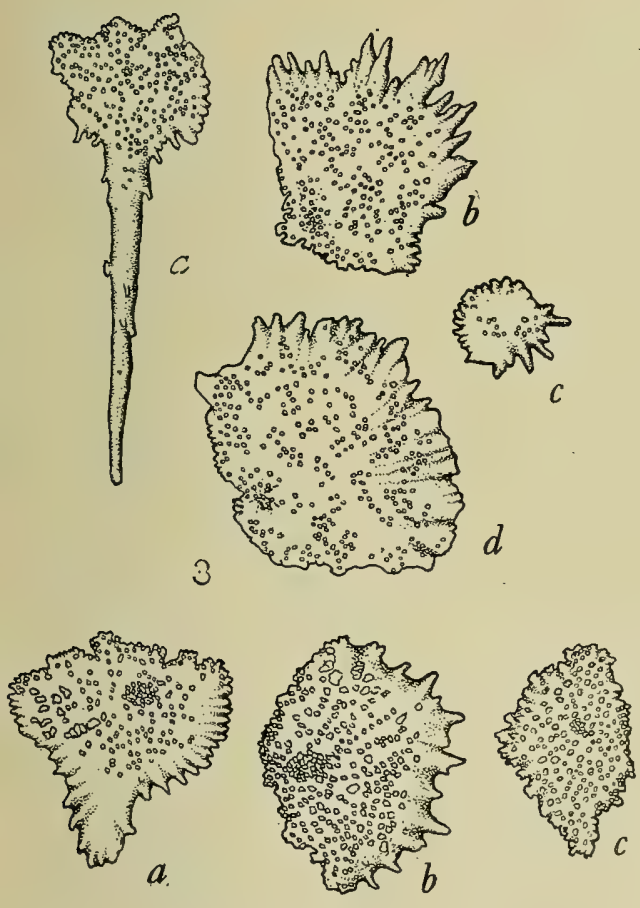

4
PROCEEDINGS, VOL. 43 PL. 19

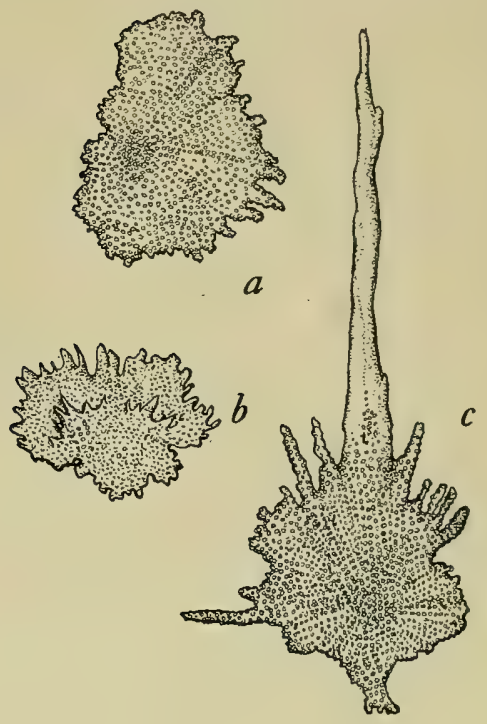

2

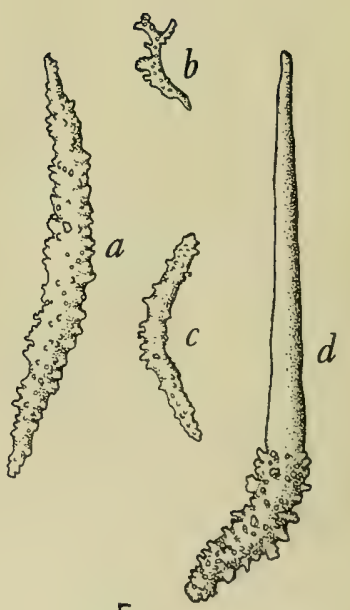

5

ALCYONARIA FROM THE NORTHWEST PACIFIC OCEAN

For explanation of PLATE SEE PAge 104. 


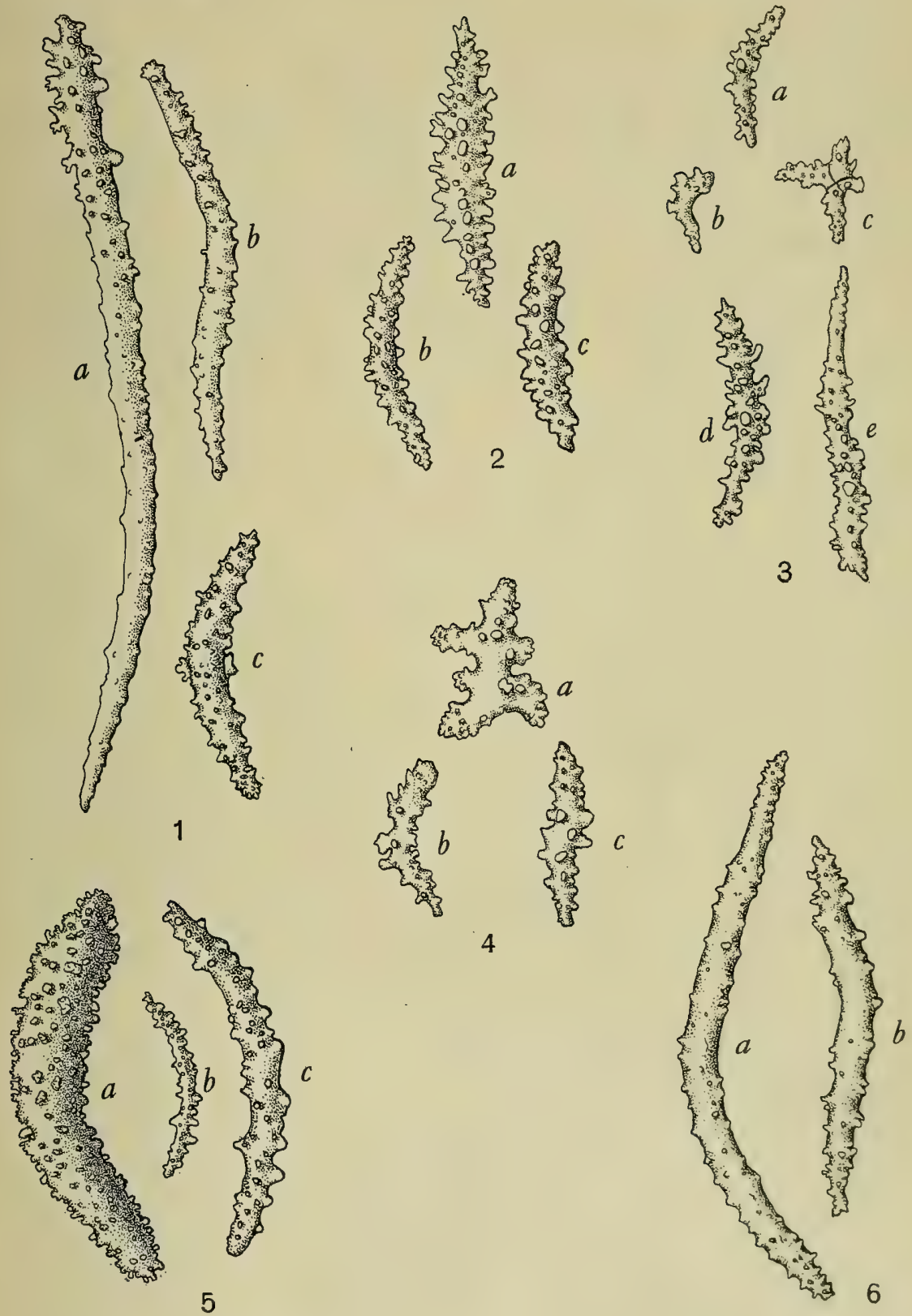

ALCYONARIA FROM THE NORTHWESt PACIFIC OCEAN.

For EXPLANATION OF PLATE SEE PAGE 104. 

U. S. NATIONAL MUSEUM
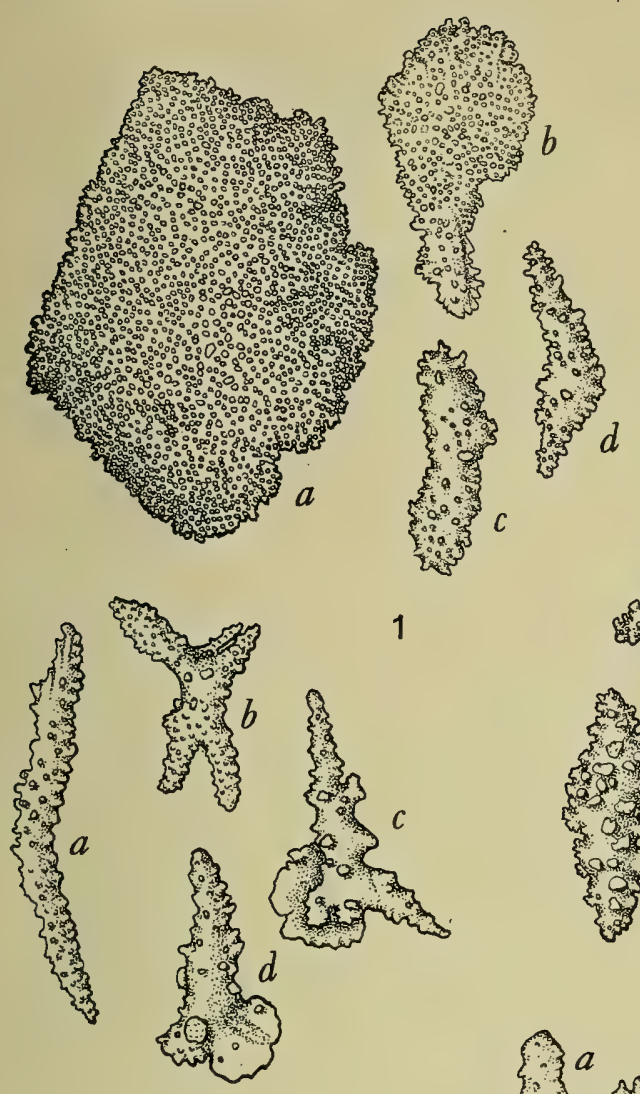

3

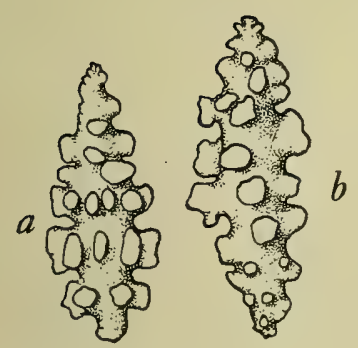

5
PROCEEDINGS, VOL. 43 PL. 21

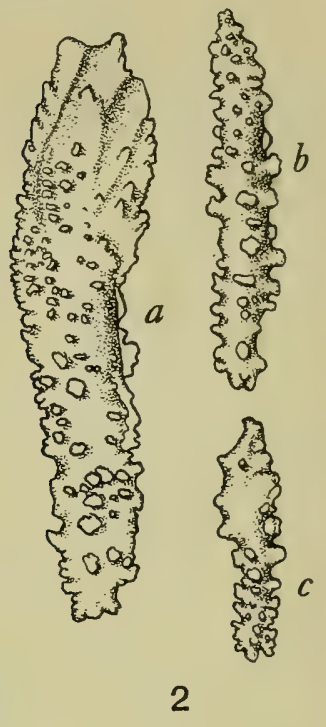

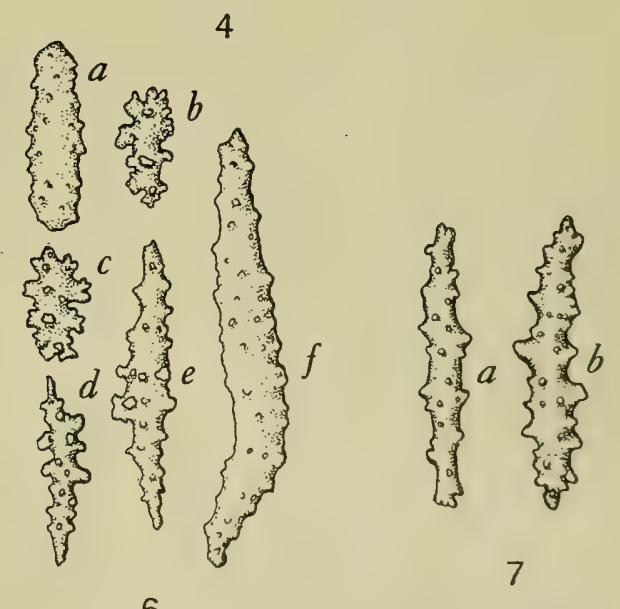

ALCYONARIA FROM THE NORTHWEST PACIFIC OCEAN.

FOR EXPLANATION OF PLATE SEE PAgE 104. 


$\uparrow$ 







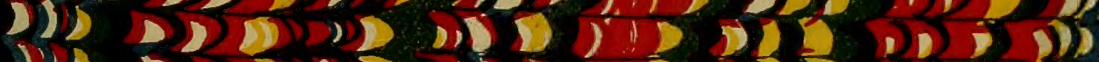

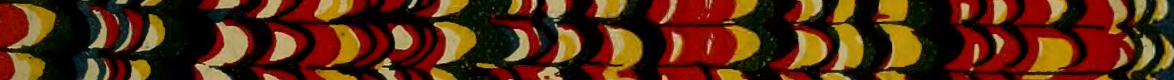

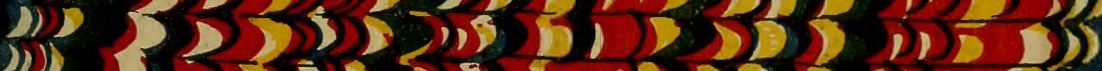

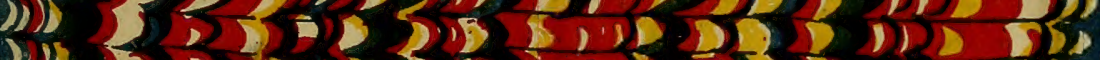

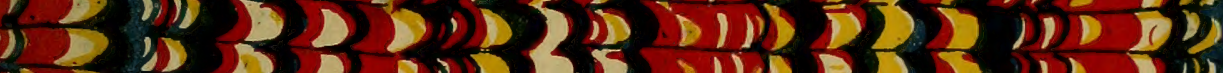

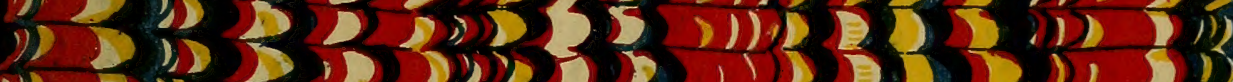

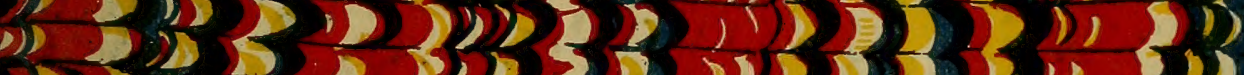

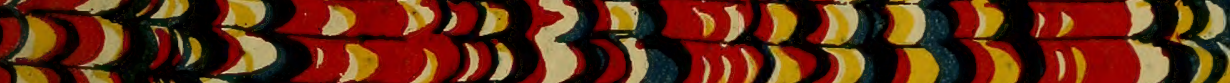

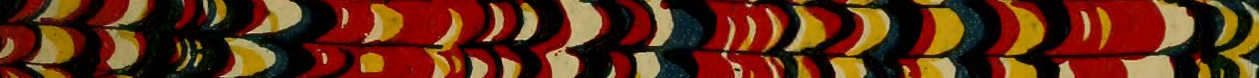

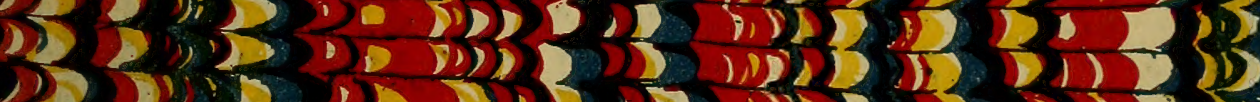

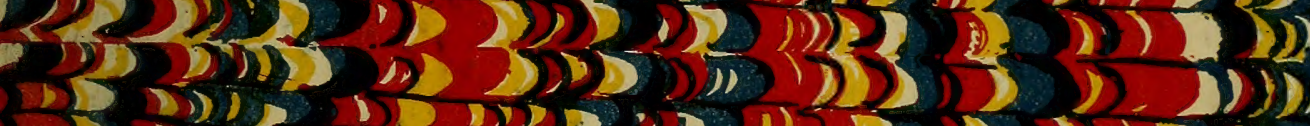

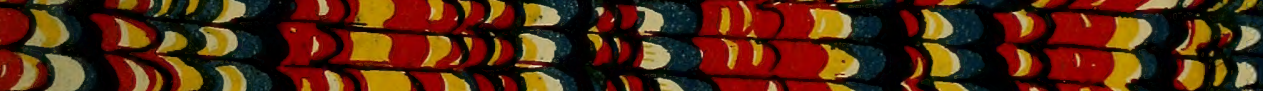

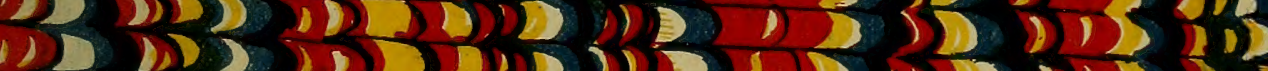

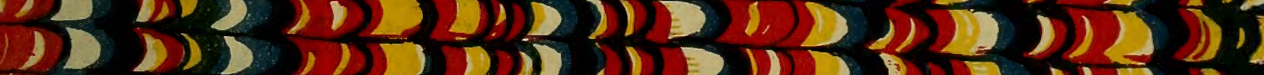

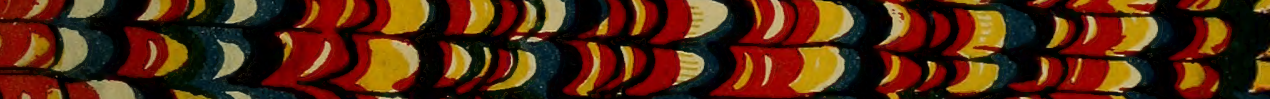

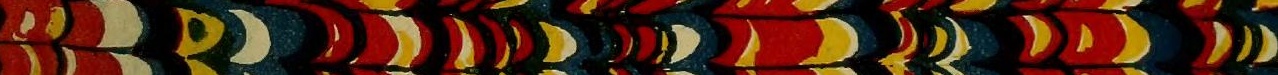

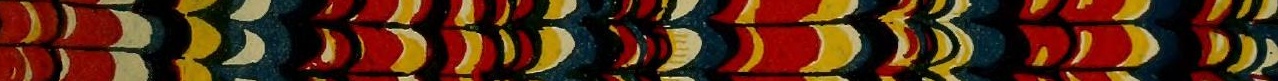

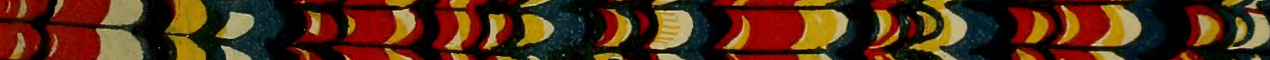

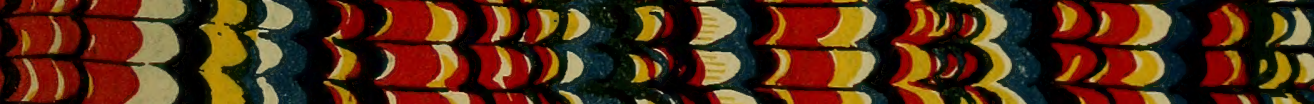

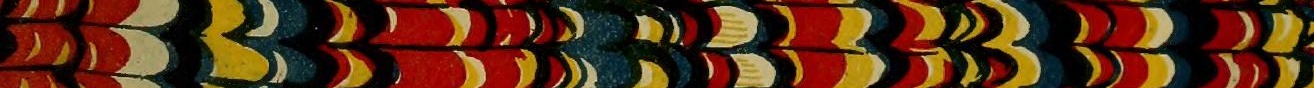

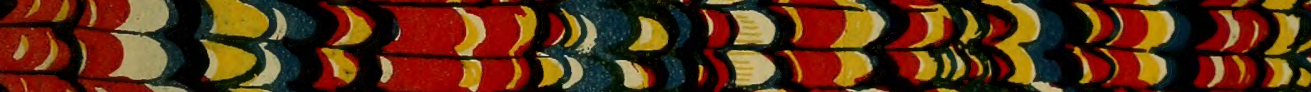

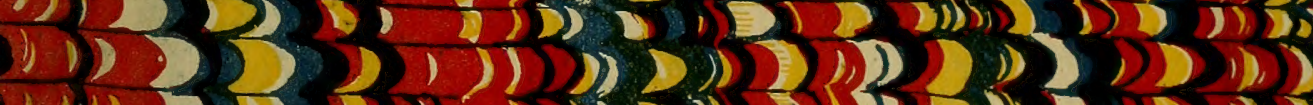

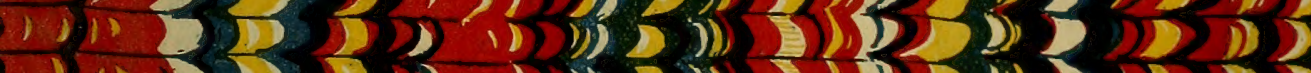

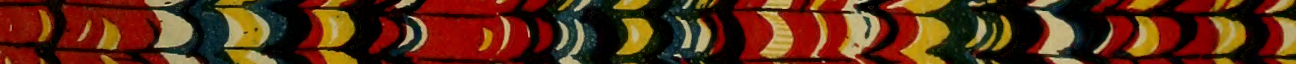

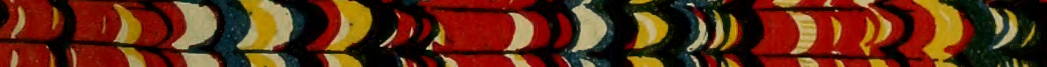

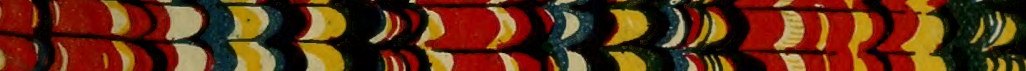

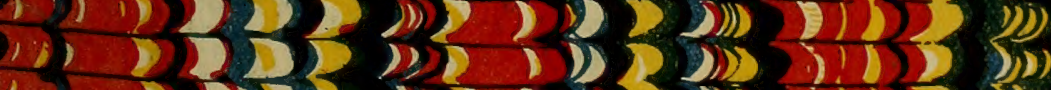
2) 21 12022012012

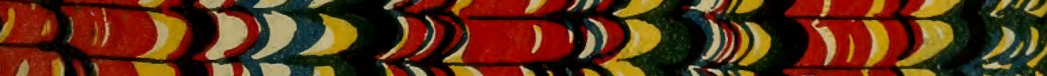

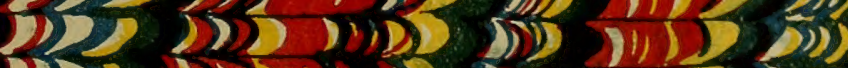

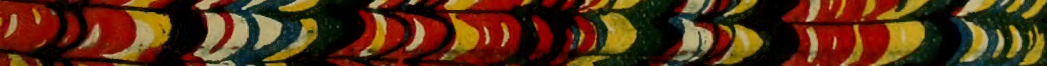
2.212 
